\title{
Figurações contemporâneas do espaço na literatura
}

\author{
Sérgio Vicente Motta \\ Susanna Busato \\ (orgs.)
}

MOTTA, SV., and BUSATO, S., orgs. Figurações contemporâneas do espaço na literatura [online]. São Paulo: Editora UNESP; São Paulo: Cultura Acadêmica, 2010. 133 p. ISBN 978-85-7983-099-0. Available from SciELO Books <http://books.scielo.org>.

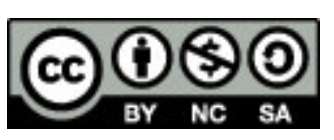

All the contents of this work, except where otherwise noted, is licensed under a Creative Commons Attribution-Non Commercial-ShareAlike 3.0 Unported.

Todo o conteúdo deste trabalho, exceto quando houver ressalva, é publicado sob a licença Creative Commons Atribuição Uso Não Comercial - Partilha nos Mesmos Termos 3.0 Não adaptada.

Todo el contenido de esta obra, excepto donde se indique lo contrario, está bajo licencia de la licencia Creative Commons Reconocimento-NoComercial-CompartirIgual 3.0 Unported. 


\section{Figurações CONTEMPORÂNEAS DO ESPAÇO NA LITERATURA}


CONSELHO EDITORIAL ACADÊMICO

Responsável pela publicação desta obra

Gisele Manganelli Fernandes

Orlando Nunes Amorim

Sônia Helena de O. Raymundo Piteri

Susanna Busato 


\section{SÉRGIO VICENTE MOTTA SUSANNA BUSATO \\ (Orgs.)}

\section{Figurações CONTEMPORÂNEAS DO ESPAÇO NA LITERATURA}




\section{(C) 2010 Editora UNESP}

\section{Cultura Acadêmica}

Praça da Sé, 108

01001-900 - São Paulo - SP

Tel.: (0xx11) 3242-7171

Fax: (0xx11) 3242-7172

www.editoraunesp.com.br

feu@editora.unesp.br

CIP - Brasil. Catalogação na fonte

Sindicato Nacional dos Editores de Livros, RJ

F497

Figurações contemporâneas do espaço na literatura / Sérgio Vicente Motta, Susanna Busato (orgs.). - São Paulo : Cultura Acadêmica, 2010.

il.

Inclui bibliografia

ISBN 978-85-7983-099-0

1. Literatura - História e crítica. 2. Espaço na literatura. 3. Análise do discurso literário. I. Motta, Sérgio Vicente. II. Busato, Susanna. 10-0128.

CDD: 809

CDU: 82.09

Este livro é publicado pelo Programa de Publicações Digitais da Pró-Reitoria de Pós-Graduação da Universidade Estadual Paulista "Júlio de Mesquita Filho" (UNESP)

Editora afiliada:

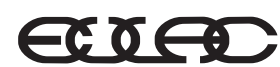

Asociación de Editoriales Universitarias de América Latina y el Caribe

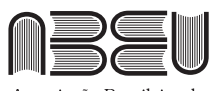

Associação Brasileira de Editoras Universitárias 


\section{SUMÁRIO}

Apresentação - Espaço em movimento: novas configurações 7

1 A consciência do zero como a lógica da razão antropofágica da poesia brasileira contemporânea 11 Susanna Busato

2 O espaço libidinal da leitura e da escrita em Llansol 27 Sônia Helena de O. Raymundo Piteri

3 Da literatura como espaço fotográfico-pictórico em textos reescritos de Dalton Trevisan 37

Arnaldo Franco Junior

4 À procura de ilhas (des)conhecidas 65 Maria Heloísa Martins Dias

5 Machado de Assis à luz do cinema de Sérgio Bianchi: o espaço em movimento 79 Sérgio Vicente Motta

6 Folhetins d'aquém e d'além-mar:

a formação da crônica no Brasil 111 Lúcia Granja 


\section{APRESENTAÇÃo ESPAÇO EM MOVIMENTO: NOVAS CONFIGURAÇÕES}

Figurações contemporâneas do espaço na literatura abre-se a uma diversidade de acepções que o conceito de espaço abriga nos objetos e cenários literários contemporâneos. O próprio texto como um espaço espacializante, na sua textualidade como corpo ou na visualidade da escrita, configura um espaço de linguagem. O contexto cultural e histórico envolve referências e dados situados em determinados momentos que articulam um espaço de relações com o texto literário. O espaço da institucionalização, com as representações de poder, o espaço social, o espaço como paisagem, nas configurações natural, regional, física e psicológica, e o espaço do mito, com suas imagens e sentidos simbólicos, são outras formas de mobilização do conceito. O espaço pictórico, quer como elemento componente da pintura ou como a própria linguagem na composição da escritura, que se vale de técnicas plásticas, também é contemplado, assim como esse tipo de diálogo abriga outros meios e linguagens, como o cinema, a propaganda, a fotografia, nas relações entre as artes.

Há também a possibilidade de se rever o objeto literário, em termos de espacialidade, sob essa perspectiva múltipla do olhar contemporâneo. Ou seja, no lugar daquele sentido restrito de categoria estrutural, o conceito incorpora uma visão ampla e metafórica, dentro da qual o próprio texto faz emergir uma concepção e função da espa- 
cialidade por meio de suas estratégias de construção. Diante de tantas possibilidades de leitura do conceito, o presente livro reúne textos de docentes do Programa de Pós-Graduação em Letras da Universidade Estadual Paulista (UNESP), campus de São José do Rio Preto, que abordam aspectos da simbolização espacial em obras literárias que implicam um olhar contemporâneo para essas figurações.

No primeiro texto, Susanna Busato traz uma reflexão sobre a experiência da recusa ou do deslocamento na poesia brasileira contemporânea em "A consciência do zero como a lógica da razão antropofágica da poesia brasileira contemporânea”. A partir da imagem do "vazio" como um espaço de contradições do tempo presente, o ensaio se concentra na poesia de Frederico Barbosa, cuja linguagem poética atua como uma revisão crítica da linguagem que se torna criação, afirmando-se como um processo de invenção.

Em "O espaço libidinal da leitura e da escrita em Llansol”, Sônia Helena de O. Raymundo Piteri explora a confluência da escrita e da leitura na obra da escritora portuguesa contemporânea Maria Gabriela Llansol. O texto mostra como a escritora, sob uma perspectiva diferenciada, alia corpo e mente num todo indiscernível e harmônico ao criar combinações como "sexo de ler" e "luar libidinal". Também demonstra como, paralelamente, há uma consonância entre o escrevente e o legente, na medida em que o ato de leitura é incitado pela energia procedente do sexo, que, por sua vez, advém da luz que incide sobre o escrevente no momento da construção do texto.

Arnaldo Franco Junior aborda, no capítulo "Da literatura como espaço fotográfico-pictórico em textos reescritos de Dalton Trevisan", relações entre literatura, fotografia e artes plásticas. O ensaísta demonstra que, no projeto literário e na escrita singulares do escritor, a literatura, desde o seu suporte primeiro - o espaço em branco da folha de papel - até a sua constituição como espaço plástico, é passível de ser concebida como imagem que remete à fotografia e/ou à pintura.

O texto "À procura de ilhas (des)conhecidas", de Maria Heloísa Martins Dias, desenvolve uma análise crítica de distintos textos com o propósito de desvendar como se configuram, por procedimentos de construção da linguagem, espaços em que se tramam relações iden- 
titárias e culturais. Assim, a narrativa $O$ conto da ilha desconhecida (José Saramago), o romance $O$ amor nos tempos do cólera (García Márquez), os contos "A mulher que prendeu a chuva" e "Roma" (Teolinda Gersão) e os poemas "Quando a pátria lasciva espalha os seus odores" e "Nada indica à Figura uma só linha solar" (António Ramos Rosa) revelam variadas estratégias de abordagem para se colocarem em cena as tensões entre o sujeito e o outro quanto às suas formas de resposta às diferenças culturais e ao desconhecido.

Sérgio Vicente Motta, no capítulo "Machado de Assis à luz do cinema de Sérgio Bianchi: o espaço em movimento", analisa como o cineasta, no filme Quanto vale ou é por quilo?, uma livre adaptação do conto "Pai contra mãe" de Machado de Assis, desenvolve os principais recursos de composição e amplia os temas do conto, por meio de sugestivas correspondências na linguagem do cinema. No plano formal, os efeitos histórico-documental e ficcional são traduzidos em gêneros discursivos alusivos à estratificação social configurada no conto. As linhas temáticas, partindo de uma situação histórico-social do passado escravocrata, são deslocadas e ampliadas em uma complexa trama armada no tecido da sociedade brasileira contemporânea. Na trajetória do passado para o presente, da origem do "homem livre" e do "mecanismo do favor" para os esquemas de corrupção e intermediações institucionalizados, em forma de projetos assistenciais, que fazem da pobreza uma mercadoria de lucro, o filme reduplica e dinamiza, em várias histórias, as relações estabelecidas na estrutura matricial, dando movimento e sentido a todo esse jogo da espacialidade social. No filme de Sérgio Bianchi, a literatura de Machado ganha forma e um sentido atemporal.

Lúcia Granja, em "Folhetins d'aquém e d'além-mar: a formação da crônica no Brasil”, discute o papel que o bas de page/rodapé teve no desenvolvimento do gênero "crônica" no Brasil. Por meio da análise de textos de nossos primeiros cronistas, verifica a função do espaço em que eram publicados esses textos, uma vez que critérios editoriais e tipográficos determinaram, por exemplo, que dois textos de gêneros diferentes compartilhassem o mesmo rodapé ou, ainda, que o romance-folhetim fosse interrompido de maneira diversa em 
relação ao original francês. A flexibilidade do bas de page/rodapé, no qual era possível a coexistência de textos de natureza diferente (críticos, imaginários, de variedades), é considerada como uma das principais razões para o desenvolvimento das especificidades da crônica no Brasil.

Sérgio Vicente Motta

Susanna Busato 


\section{1 \\ A CONSCIÊNCIA DO ZERO COMO \\ A LÓGICA DA RAZÃO ANTROPOFÁGICA \\ DA POESIA BRASILEIRA CONTEMPORÂNEA}

Susanna Busato*

Como trilhar os caminhos que hoje a poesia brasileira constrói em termos de uma consciência crítica da linguagem? Seguir o roteiro das dimensões de espaço e tempo, por meio das quais a poesia de hoje organiza o seu espaço de linguagem, é uma trilha possível e necessária para compreender um tempo de traçados vários, que vão alinhavando e indicando os roteiros que pretendem seguir, de modos diferentes, uma trajetória de recusa para o mesmo.

A experiência da recusa ou do deslocamento implica sempre um gesto crítico. A consciência de um tempo presente revela-se hoje como flagrante do "vazio" e como imagem do "obstáculo". Consciência que emerge, por exemplo, como aquela que, para o sujeito do poema de Manuel Bandeira (1982, p.93):

Momento num café, tomara o sentido do espaço, ocupado num primeiro momento enquanto imagem denotada da existência, para perceber-se como margem para um espaço metafísico, transcendente e conotado, considerado como desvio no paradoxo flagrado: "a vida é traição", [diante da matéria] que passava/Liberta para sempre da alma extinta.

* Doutora em Letras pela Universidade Estadual Paulista (UNESP) e professora-assistente da mesma instituição, campus de São José do Rio Preto. 
O vazio se descobre um "boi morto", imenso, espantoso, "Morto, sem forma ou sentido/ou significado" (ibidem, p.145). Ao olhar a matéria "liberta para sempre da alma extinta", o sujeito do poema, deslocado da esfera da vida-confiança, da vida-absorção, da vidacerteza, descobre-se "num gesto largo e demorado", numa perspectiva de tempo perceptivo que se expressa em revelação (muito mais do que em sinal de respeito, em termos do protocolo social). Seu gesto é descoberta e recusa na compreensão não da morte terrena, do corpo inerte às pulsões de vida já extintas de suas células, mas da morte como libertação dos atavismos, do corpo como cárcere, como casca simbólica dos automatismos que imprimem aos gestos uma ideia de vida como estado de permanente sensação de passagem pelas estações do tempo linear e mecânico, marcado pelo relógio controlador dos desejos e das voracidades: "Este sabia que a vida é uma agitação feroz e sem finalidade./ Que a vida é traição" (ibidem, p.93).

Um dos grandes paradoxos da vida é afirmar que a vida é um beco sem saída. Essa ideia de beco, de espaço emoldurado pelas ações coercitivas do cotidiano, transforma-se na arte como o lugar a ser devorado pela consciência do "nada" que anima hoje a poesia brasileira:

negar o nada

para instalar o reverso:

talvez do negado brote um mutante avesso afirmativo

um ser que se inaugure no limbo ainda que sendo só um símbolo (Tápia, 2009)

Assinalar o vazio da existência, a não utopia, a não saída, tornase para a poesia hoje um roteiro dela própria. Propõe o poema "O nada negado", de Marcelo Tápia (2009), um jogo: "negar o nada" 
para inaugurar um "avesso afirmativo", ou seja, para inaugurar um dizer, uma voz que signifique, que extraia do agora, desta atmosfera em que "tudo está dito" (alusão ao poema de Augusto de Campos, que também devora esse nada que se abre nas dimensões da modernidade), a poesia como desafio, como uma nova experiência de linguagem, como uma nova experiência de dizer a tal pedra de Drummond, que invade o poema como um ruído que não silencia e inaugura, para a poesia brasileira de vanguarda, no início do século $\mathrm{XX}$, o tom de desolação ante um mundo que descobre o homem como caco, resíduo de tempo, verme que nasce daquilo que sobra de si próprio quando suas certezas de existência veem-se abaladas por um mundo centralizador de poderes totalitários, dominadores das ações sociais e de um poder capitalista liberal que deixa livres as ações castradoras da liberdade humana. Edgar Morin (1999) assinala que houve, na passagem do século XX ao XXI, "a destruição, ou melhor, a autodestruição da idéia de salvação terrestre", o que implica compreender que "não existem leis históricas, que o progresso não é automático e nem se encontra garantido", ou seja, que aquilo em que se acreditava como evolução "certa e reta" no desenvolvimento da humanidade ligado ao desenvolvimento da ciência, como algo progressivo e assegurador do "reino de felicidade", traz justamente o oposto, o desabamento das utopias e das crenças no futuro. A sociedade de consumo e informatizada apenas acredita no aqui e agora de seu estado de comunicação. O imediatismo e a falta de verticalidade nas relações humanas destroem a crença no futuro.

O poema de Marcelo Tápia solicita, pois, como poesia, a saída do labirinto: necessário se faz apontar o vazio e fazer dele matéria de poesia, cuja tarefa, por sua vez, emerge do cotidiano do homem e como um verme vai devorando tudo o que encontra, até mesmo o próprio homem.

Uma questão importante para a compreensão do espaço e tempo estéticos que a poesia hoje configura é perceber a relação complexa entre "linguagem e realidade". Em outras palavras, seria verificar como o período estético que habitamos se posiciona pela "recusa ou redefinição de um código anterior" e como se organiza "pela invenção 
de elementos formalizadores para o futuro" (Barbosa, 1974, p.93). O gesto que constrói o espaço poético do agora é um gesto que se posiciona num espaço pós-utópico, segundo a proposição feita por Haroldo de Campos (1984, p.5). O espaço da poesia do presente seria o espaço de "uma poesia de pós-vanguarda, não porque seja pós-moderna ou anti-moderna, mas porque é pós-utópica”. A pósutopia poderia ser explicada por meio da assertiva de que ao "projeto totalizador da vanguarda [...] sucede a pluralização das poéticas possíveis. Ao princípio-esperança, voltado para o futuro, sucede o princípio-realidade, fundamentalmente ancorado no presente" (ibidem). Octavio Paz, em Os filhos do barro, dirá que "a poesia de hoje é uma poesia do 'agora”" (apud Campos, 1984, p.5). Um “agora" como marca temporal daquilo que não é mais, pois o presente é transitório: nossa época "não conhece senão sínteses provisórias e o único resíduo utópico que nele pode e deve permanecer é a dimensão crítica e dialógica que inere à utopia”, afirmará Haroldo de Campos (1984, p.5). Na releitura do passado e na ação de "recombinar criticamente a pluralidade dos passados possíveis", presentificando como diferença essa poesia no poema pós-utópico (ibidem), é que a poesia do presente assumiria seu caráter antropofágico.

É assim a poesia que constrói um espaço crítico onde os "destroços do presente" provocam no sujeito a sensação de estar "a meio submergido", "dividido, subdividido" (Bandeira, 1982, p.145). É assim a poesia cujo olhar crítico emerge da linguagem e do discurso crítico como matéria anímica com que Drummond (1983, p.201) já flagrara em "Cerâmica" o revés da existência:

Os cacos da vida, colados, formam uma estranha xícara.

Sem uso,

Ela nos espia do aparador.

A vida como ruptura, como caos, como desfuncionalizada de seu percurso linear, a "vida como traição", promove para o sujeito uma nova ordem. Na imagem da "xícara", a desfuncionalização impressa nos cacos colados, nos resíduos agrupados numa ordem que lembra 
de longe um dado de realidade. É assim que a imagem da vida desconstruída por via da palavra "nos espia do aparador", sinal de ironia desse vazio que marca o estranho de nós mesmos.

A expressão da morte enquanto imagem da libertação das molduras pacificadoras da linguagem emerge no poema de Bandeira e no de Drummond como um dado metalinguístico da consciência do poético e do mundo presente. Emerge como a imagem da consciência do não lugar, motor de uma razão antropofágica, de um gesto de devoração e de recusa ao já visto, ao já acostumado e já confortavelmente instalado. Talvez seja o gesto de recusa na poesia de hoje uma expressão roteirizadora de uma saída, por isso a força de uma metalinguagem devoradora do caos presente, analítica, raciocinante, centrada nas sensações de um sujeito que se percebe imerso, "submergido/entre os destroços do presente" ou submetido à repetição simuladora do caos, como se preso estivesse a um "labirinto dificultoso", cuja saída parece submergir a inércia do movimento.

A imagem da "diferença" que emerge do pensamento acerca da poesia do presente pós-vanguarda vai encontrar-se como ponto nodal no gesto de "recusa" da poética de Frederico Barbosa, ${ }^{1}$ a qual estaria num movimento de recuo para um ponto original, um hiato, abismo ou intervalo, que emerge necessário numa voz que se marca por uma "metaironia", ou seja, por uma crítica que se torna criação e que se afirma, portanto, num processo de revisão crítica da linguagem poética, ao assinalar o imenso "nada" em que se situa. Mais do que uma negação, a consciência do tempo presente como a "consciência do zero" é o ponto de partida ou de chegada desse "nada" ou "quase nada" do momento presente, que representa esta pós-modernidade

1 Em 1990, Frederico Barbosa estreia com o livro Rarefato e segue adiante em sua trajetória poética com os livros Nada feito nada (1993), Contracorrente (2000), Louco no oco sem beiras - Anatomia da depressão (2001), Cantar de amor entre os escombros (2003), Brasibraseiro (com Antônio Risério) (2004) e A consciência do zero (2004). Barbosa recebeu dois prêmios Jabuti pelos livros Nada feito nada, Brasibraseiro e SigniCidade (2009). Em meio à produção pessoal, publicou coletâneas de poemas, com destaque para Na virada do século-Poesia de invenção no Brasil (com Cláudio Daniel) (2002). 
à beira da entropia pelo excesso de repetição a que está fadada qual narciso, eternamente se mirando em seu reflexo tardio. A "consciência do zero" é uma imagem da qual me aproprio aqui numa referência ao conjunto de poemas com que o poeta Frederico Barbosa inicia sua trajetória poética com o livro Rarefato, de 1990. Sua "trilogia do tédio", escrita em 1984, inicia esse percurso da negação do sujeito no espaço, que se rarefaz em silêncio:

Nenhuma voz humana aqui se pronuncia chove um fantasma anárquico, demolidor

amplo nada no vazio deste deserto anuncia-se como ausência, carne em unha

odor silencioso no vento escarpa corte de um espectro pousando na água tudo que escoa em silêncio em tempo ecoa (Barbosa, 1990, p.3)

A estrutura do poema traz esse "nada" nos espaços intervalares ao longo dos versos, construindo um ritmo pausado que se autorreferencia no trajeto dos sintagmas como sendo a própria consciência da ausência, no "aqui" do poema ("nenhuma voz humana aqui se pronuncia”), que se presentifica por metáforas ao longo dos versos: imagens espectrais ("chove um fantasma anárquico"; "espectro pousando na água”), imagens amplificadoras da ausência ("amplo nada no vazio deste deserto"), sinestésicas ("odor silencioso no vento"), numa construção rítmico-sonora que encontra a fluidez já anunciada do espectro do silêncio no último verso: "tudo que escoa em silêncio em tempo ecoa". Eis a consciência de um tempo que é flagrado nos espaços lacunares construídos entre as palavras. Eis a consciência de um tempo (denotado) que é flagrado como silêncio projetado para o tempo (conotado) do poema, que o ecoa na plasticidade dos versos, ou seja, nos espaços gráficos que mimetizam o vazio ("que escoa em silêncio”); nas imagens semânticas do vazio, no ritmo desacelerado; nas aliterações das sibilantes e chiantes, assim como das nasais, como 
espectros de "silêncio" que ecoam como imagem do "nada" espacial que assombra o poema; e nas assonâncias das vogais abertas que vão dando plasticidade ao "nada" como uma figura "aberta", "vazia", "esvazada”. Essa "consciência do zero" instaura, na voz que emana do poema, o início de uma trajetória crítica que irá buscar no aspecto do transitório, ou seja, daquilo que flui e escapa, que chega e parte, o elemento da presença do poético nesse contexto "pós-tudo", imagem que o poema de Augusto de Campos (2010) ousara criar em meados dos anos 1980 para provocar esse momento pós-vanguarda, pósutópico, imerso no flagrante da consciência do "quis mudar tudo/ mudei tudo/agorapóstudo/extudo/mudo".

Aquilo que é rarefação de sentidos, esvaziamento e redundância gera grau zero de informação, fora das molduras da arte. "Rarefato" é sinônimo de rarefeito; de rarefactum, diminuído na densidade, de onde "rarefazer" é tornar menos numeroso ou menos frequente. Em que medida essa ação de "rarefazer" estaria encenada como voz nos poemas? O "nada" em que se traduz o verbo é um agente demolidor que escoa em silêncio e ecoa no tempo, está presente no poema e na realidade que atinge o poeta. Ao assegurar sua presença, o poeta constrói-lhe um espaço de representação. Os espaços em branco no poema incomodam, pois sua presença é como um "corte do espectro" (o vazio mimetiza o espectro, o corte na sintaxe do verso mimetiza a presença intrusa desse outro que assombra o poeta). Uma das saídas para o vazio é deslocar-se no espaço e no tempo, é buscar no elemento do transitório a presença de um espaço de referências que irão trazer informação nova ao verso: a diferenciação de formas e funções para a poesia é o resultado do gesto de recusa que tem na "consciência do zero" o lugar da trajetória, seu ponto de partida e seu ponto de chegada, pois fadado está o poeta a se deparar com a dor da náusea, com a depressão, como uma estratégia, enfim, para chegar mais próximo ao ponto máximo dessa trajetória, o ponto zero, intervalar entre dois polos, o positivo e o negativo, lugares da hesitação e do risco. Irá procurar o poeta encontrar-se com o verso na sua essência crítica de verso, ou seja, na sua crise perpétua, buscando na célula do ritmo o alcance para transitar por composições que irão remeter aos jogos labirínticos do barroco, aos jogos com palavras da poesia concreta, aos versos cadenciados de 
uma educação pela pedra, bem ao gosto das lições de João Cabral, ou à viagem pela memória do passado como em Manuel Bandeira, muitas vezes regado pelo pessimismo de Drummond, mas sem deixar para trás a ironia necessária e mordaz de um Oswald de Andrade.

A "consciência do zero" é a consciência do início, de um tempo que escoa em silêncio para ressurgir nesse gesto que se anuncia no poema como uma reflexão/ação da recusa ao já feito: "Sentia o término nas veias." afirma a segunda parte do poema. Em meio ao filme ruim num cinema lotado, diz o poema, enfim, em meio a uma atmosfera terminal, negativa, representada por um contexto que não mais produz significâncias, o sujeito pressente o pânico que se anuncia e, logo, vem-lhe o estalo: "a consciência do zero rondando", a consciência de um vácuo, como uma bolha frágil. Os versos caminham na descrição da cena/percepção do instante que rui no sujeito a realidade em redor, para transformá-la em linguagem, presença de uma ausência mimetizada em reação: "Estado, condição, estado. / Abre:". Os dois versos finais trazem esse sujeito inserido num espaço emoldurado por uma consciência de "estado" que o traduz em "condição", mera repetição que anuncia o caos, a explosão da bolha: "Abre:”. Esse verso final aponta para a terceira parte da "trilogia do tédio", que revela, já, o espaço a que o sujeito é reportado durante o "estalo" de consciência desse ponto intervalar que é o zero (fronteira entre o nada e o tudo, entre o acaso e a necessidade, entre a palavra e o silêncio): a poesia inicia o seu trajeto no mergulho dessa consciência no espaço mesmo da linguagem. A construção do poema enuncia, no decassílabo dos versos, o eco de um tempo que plasma o espaço de um "crime" que se anuncia:

Dominado pela pedra, insone, descolorido, o crime principia nas altas horas da noite vazia ganha corpo no decorrer do dia.

Ganha corpo no decorrer do dia, dor de náusea delicada e infame descolorido, o crime principia alia-se ao tédio impune e some. (Barbosa, 1990, p.5) 
De onde o poeta deflagraria seu gesto de recusa? É no eco da composição do verso clássico de Camões que a poesia que se insurge no agora desse "pós-tudo" deflagrará o gesto de recusa, ou seja, o gesto que nega camuflar-se à sombra da vanguarda, repetindo-a. O poema traz a dicção de uma estrutura poética que remonta a um processo barroco de construção, por meio da repetição dos sintagmas ao longo das estrofes em combinações várias, sempre remetendo ao início do processo, sem achar saída. A imagem da pedra, já presente na tradição poética como metáfora do tempo e da palavra, principia nesse poema a dicção da poesia para o poeta e revela, pelo jogo dos versos que se dobram e redobram nesse dizer/mostrar, o que a pedra insone entranha na alma do poeta: conhecimento da efemeridade da própria poesia e da própria vida.

Dor de náusea delicada, infame, nas altas horas na noite vazia ganha corpo no decorrer, no dia dominada pela pedra, insone.

Ganha corpo no decorrer do dia, dor de náusea delicada e infame descolorido, o crime principia alia-se ao tédio impune e some. (ibidem)

Articula o sujeito do poema, como um "crime" que vai ganhando corpo no poema e "no decorrer do dia" e "nas altas horas da noite vazia", essa "dor de náusea" ante o "vazio provável" da própria poesia aliada "ao tédio impune". Percebe-se o poema como um gesto anunciador daquilo que a poesia de Frederico Barbosa irá perseguir ao longo de sua obra: a negação do mesmo por um processo que mimetiza esse "mesmo" como agente do tédio e do incômodo do sujeito, que já não se avizinha do gesto revolucionário da vanguarda, na qual parece não crer, procurando na tradição poética a dicção necessária para religar o poeta às coisas, sentimentos e memórias de seu próprio tempo, por meio de uma operação tradutora dessa mesma 
tradição (caso contrário, seria um retorno nostálgico e, de fato, não é isso que representaria o gesto de recusa com que roteiriza sua dicção poética). Assim, o gesto que o aproxima daquilo que se lhe afigura como parte de sua experiência (a cidade, as pessoas flagradas na sua passagem, os amores pessoais, a memória da infância e da leitura de ritmos e gêneros literários, musicais e cinematográficos) aponta, nesse trajeto, um processo necessário de deslocamento, que traz, na sua natureza, o desejo de abarcar a pluralidade de um tempo, o seu e o da cultura.

Ganha corpo o poema num entrelaçar de enunciados que se referem à "dor de náusea", esse incômodo que retoma o seu lugar num processo de não avançar, pois o sujeito é "dominado pela pedra insone", pelo poema que o enreda nesse labirinto locutório de uma "consciência do zero rondando", em círculos que se abrem em espirais, para, no final do poema, essa dor insone de náusea delicada e infame aliar-se ao tédio impune e sumir, como a outra ponta da espiral. Na verdade, o poema já revela, na sua estrutura, o processo da rarefação como o gesto de uma procura de sua própria poética.

No livro Nada feito nada, de 1993, Frederico Barbosa retoma a temática do vazio num projeto de enfrentamento e de devoração que lhe vale o gosto pela experimentação sempre nova, como a rasgar, na linguagem, o crivo crítico daquele que se integra como corpo na poesia de seu tempo. A epígrafe de abertura da obra traz os dois primeiros versos do poema, do qual transcrevo a seguir somente a primeira estrofe, do trovador provençal Guilhem de Peitieu, cuja atualidade em muito surpreende:

Farai um vers de dreit nien:

Non er de mi ni d'autra gen

Non er d'amor ni de joven,

$\mathrm{Ni}$ de ren au,

Qu'enans fo trobatz em durmen

Sus um chivau. 
A tradução literal' seria: "Farei um verso sobre nada, / nem sobre mim nem sobre alguém". A que viriam os versos de Nada sobre nada? Esvaziar logo de início a expectativa do canto como um canto sobre nada é trazer à tona a margem da palavra que se busca como negação de tudo e como rarefação das certezas. Novamente, a crítica sob os poros do canto, inserindo-se como linguagem, desenhando o "nada" como forma de um dizer que busca uma saída para si próprio e para a poesia de seu tempo.

\section{LABYRINTHO DIFFICULTOSO}

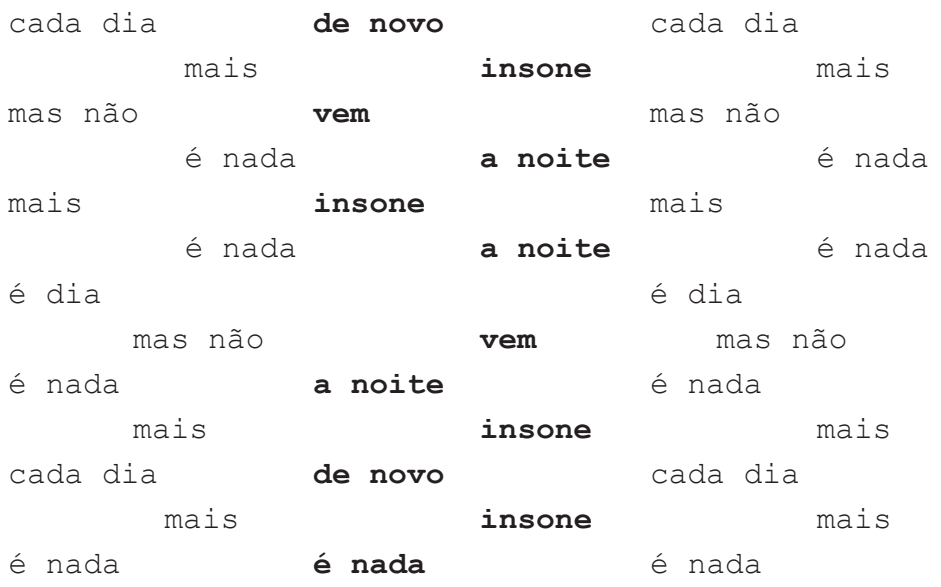

(ibidem, p.13)

"Labyrintho difficultoso" está inserido na primeira parte do livro que se intitula "Ocasionais". O nome sugere espaços e tempos de "ocasos", crepusculares, finais, epigonais, mergulhados numa atmosfera de um ultimatum escrito em versos, deflagrando no poema sua impotência, o seu nada:

2 Faço a tradução com base na tradução para o inglês de James J. Wilhelm (1990, p.54). 
o poema

nada

faz-

ou quase

se

pouco

O poema citado é de Haroldo de Campos e abre a primeira parte, dedicada a Sebastião Uchoa Leite, um poeta também de veia irônica e crítica, que sabia que a "vida é traição" e "uma agitação feroz e sem finalidade".

A forma arcaica do título remete o poema à tradição barroca dos labirintos poéticos, cuja forma ludicamente propõe uma construção dinâmica e movediça, cujas partes se intercalam e se interpolam numa exaltação dos sentidos, num jogo frenético de sobreposição. Um labirinto no qual o leitor também se imprime, ao qual também é seduzido na diagonalidade da construção. Nesse "Labyrintho difficultoso", Frederico Barbosa constrói a arquitextura do espaço espacializante de um estado de suspensão: como leitmotiv o nada, a rarefação dos dias e das noites e do tempo que insiste e não parece alterar nada. A fragmentação dos versos promove a figura de um mosaico cujas peças, móveis, se entreolham como pestanas semicerradas. A semântica dos versos é mimetizada por essa estrutura em fragmento, cujos sintagmas vão se repetindo e se expandindo a partir do sentido da própria repetição presente em: "cada dia de novo cada dia"; ou em "de novo / insone / vem / a noite / insone"; ou ainda em "mais insone mais / cada dia de novo cada dia". Recortes de leitura flagram o processo de repetição em qualquer direção. Todo processo de repetição gera informação zero, o caos, em termos da teoria da informação, ou ainda gera a entropia. O poema sabe disso e com isso se nutre: "cada dia / mais insone mais/ mas não vem mas não / é nada a noite é nada”; ou "cada dia de novo cada dia / é nada é nada é nada". É a mimetização desse caos, desse nada, pelo processo de repetição do mesmo, do cotidiano, da não passagem do tempo, ou da passagem 
que não gera movimento, que não se resolve, que a espiral do tempo é construída no espaço labiríntico do poema, desenhando a saída, paradoxalmente. Reler o barroco nesse poema, a partir da imagem do vazio em que o poeta percebe o seu tempo, é promover a saída do labirinto contemporâneo. Saída que se mimetiza em labirinto, que se nutre da racionalidade da construção para enredar o outro: reler a tradição é o gesto antropofágico a que se lança essa poesia que recusa as formas fáceis. Nestas, o poeta vislumbra o nada que assombra a poesia de seu tempo.

Em suas entrevistas e artigos, Frederico Barbosa mantém uma posição bem marcada com referência à recusa à "poesia fácil”, sem rigor formal, sem a observância do elemento crítico na sua composição. Afirma o poeta, em uma de suas entrevistas, que o exercício poético deve ser constante no sentido de "sempre procurar reinventar a linguagem, procurando novas saídas para os dilemas da linguagem e da vida" (Barbosa, 2003 apud Ribeiro, 2010). Em outro momento de suas declarações à imprensa, afirma que tem "horror à poesia "de expressão', confessional, verborrágica: banal” e "enorme admiração pela poesia 'de invenção': genial” (Barbosa, 2003 apud Machado, 2010).

O olhar do poeta, coerente com suas colocações, promove, em sua obra, uma releitura dos elementos que ainda vigoram na poesia da tradição, que remontam, por exemplo, aos poemas gregos, a $\mathrm{Pe}$ trarca e Dante, aos labirintos barrocos, à espacialização da palavra no espaço, promovendo uma reversão no verso tradicional (como a vanguarda da poesia concreta evidenciara em suas experimentações formais), e, por fim, ao rigor cabralino do ritmo e da extração da pedra/palavra, a essência que a anima ou que lhe deflagra a crise. É do poeta, tradutor e crítico literário Sebastião Uchoa Leite a declaração que faz na contracapa do livro de estreia de Frederico Barbosa, Rarefato (1990):

[...] referências cultas [que] se cruzam com outras mais acessíveis à formação média: Camus e jazz, Beckett e filmes noir, João Cabral e os faróis de automóveis. Nem tão intelectual, porém, que o poeta se 
negue à narração de sensações mais concretas, mesmo filtradas por referências a Dante e Petrarca.

Em prefácio ao livro A consciência do zero - antologia de infernos diversos, Fabiano Calixto (2004, p.9) aponta o elemento erudito no fazer poético de Frederico Barbosa, que, longe de situá-lo na esfera de uma "poesia intelectual", que teria um halo de eruditismo hermético e bem-comportado, ${ }^{3}$ situa-o num diálogo profícuo com o seu tempo e o seu leitor, na trilha que traça entre "a experimentação e o lirismo, a experiência do sujeito e a conjugação do coletivo, entre a cruz da invenção e a luz da tradição [...] promovendo aquilo que Ezra Pound tanto prezava: conversation between intelligent men".

O poeta aqui retira, pois, da tradição o elemento vivo que ainda faz reverberar no presente uma procura por uma poesia que se situa como recusa ao já feito, ao já estabelecido. A ideia de reciclagem ligada à recusa do óbvio percorre essa trajetória que se deseja singular na sua ausculta interna, ou seja, na sua imersão no universo da linguagem que se autoquestiona no espaço que aos poucos vai adquirindo contornos movediços. O sujeito e sua consciência de que não há movimento, mas uma "pausa",

acabei aqui. parece certo

final de viagem, resto deserto.

represa

água, luz, corrente em si

silêncio largo sol calor (Barbosa, 1990, p.25)

encontram-se em meio ao vazio de um tempo sem espaços possíveis:

3 Esfera a que o poeta declara sua ojeriza em prol do fazer inventivo: "Poetas advogam hoje o retorno ao verso parnasiano ou romântico, por se sentirem incapazes de carregar o fardo da busca de formas novas... Eu aposto na continuidade do projeto modernista, na manutenção do espírito revolucionário permanente. Só isso fará com que a arte siga em frente de maneira significativa" (Barbosa, 2002 apud Abyahi, 2010). 
Nada. Apalavra é nada.

O corpo sempre vazio. Nada.

Nem um som, nenhum som, nem o som.

Aberta, feroz, certa:

A palavra é nada.

Porque tudo é miragem.

Porque não há solução.

Há o que há: nada.

Há nuncas e nádegas.

Nada. (ibidem, p.41)

A poesia de Frederico Barbosa vai iniciar, a partir dos poemas de Rarefato, uma trajetória de leitura da linguagem que está imersa numa atitude singular de rasurar a paisagem do já construído, para aí instar um roteiro de leitura que vai se fazendo enquanto se busca; que vai se fazendo enquanto nega a superfície das coisas, o aparente de tudo para contrapor a ele o nada sonoro da existência, como está no poema "Rarefato - uma trilogia do tédio", já mencionado aqui.

Nenhuma voz humana aqui se pronuncia

Chove um fantasma anárquico, demolidor $[\ldots]$

Tudo que escoa em silêncio em tempo ecoa(ibidem, p.3)

O que chamo de "o nada sonoro da existência" ecoa em muitos poemas ao longo de sua obra e me leva novamente ao encontro do poema "Pós-tudo", de Augusto de Campos (2010), poema que já anunciava a obliteração de uma época entregue após o júbilo de uma modernidade aurificada. A poesia do pós-tudo é rarefeita, ou seja, carrega em si a falta, o nada que a toma de assombro. A poesia para existir deve deixar sentir a linguagem percorrer as possibilidades imagéticas do signo. Num mundo pós-utópico, desprovido do "princípio-esperança" das vanguardas, como assinala Haroldo de Campos (1985), tempo em que, parece, tudo já está dito e não há nada a inventar, o caminho a percorrer é fazer desse "nada" matéria 
de poesia, fazer desse "nada" formal a busca da forma poética no verso novamente, auscultando aquilo que a época do presente do poeta lhe oferece como eco de tantas experimentações no campo do poético. As possibilidades de trabalho com o verso são várias, e Frederico Barbosa (1990, p.31) irá colher nesses espaços sua "flor de farol", sua metáfora da poesia entrelaçada aos resíduos do agora.

\section{Referências bibliográficas}

ABYAHI, A. C. Disponível em: < http://fredbar.sites.uol.com.br/norte. html>. Acesso em: 18 abr. 2010.

ANDRADE, C. D. de. Antologia poética. 17.ed. Rio de Janeiro: Livraria José Olympio, 1983.

BANDEIRA, M. Antologia poética. 14.ed Rio de Janeiro: Livraria José Olympio, 1982.

BARBOSA, F. Rarefato. São Paulo: Iluminuras, 1990. Nada feito nada. São Paulo: Perspectiva, 1993.

A consciência do zero - antologia de infernos diversos. São Paulo: Lamparina, 2004.

BARBOSA, J. A. Metáfora crítica. São Paulo: Perspectiva, 1974.

CALIXTO, F. Telegramas na água: algumas palavras sobre a poesia de Frederico Barbosa. In: BARBOSA, F. A consciência do zero - antologia de infernos diversos. São Paulo: Lamparina, 2004. p.7-12.

CAMPOS, A. de. Pós-tudo. Disponível em: <http://www2.uol.com.br/ augustodecampos/poemas.htm>. Acesso em: 22 mar. 2010.

CAMPOS, H. de. Poesia e modernidade: o poema pós-utópico. Folha de S.Paulo, São Paulo, 14 out. 1984. Folhetim, p.3-5.

MACHADO, L. A. Disponível em: <http://www.sobresites.com/poesia/ barbosa.htm>. Acesso em: 18 abr. 2010.

MORIN, E. Amor, poesia, sabedoria. Trad. Edgar de Assis Carvalho. Rio de Janeiro: Bertrand, 1999.

PAZ, O. Os filhos do barro. Trad. Olga de Sá. Rio de Janeiro: Nova Fronteira, 1984.

RIBEIRO, A. E. Disponível em: <http://fredbar.sites.uol.com.br/estante. html>. Acesso em: 18 abr. 2010.

TÁPIA, M. Valor de uso. São Paulo: Editorial, 2009.

WILHELM, J. J. (Org.) Lyrics of the Middle Ages: an anthology. New York: Routledge, 1990. 


\section{2 \\ O ESPAÇO LIBIDINAL DA LEITURA E DA ESCRITA EM LLANSOL}

Sônia Helena de O. Raymundo Piteri*

No decurso do texto em que se expande a escrita de Maria Gabriela Llansol, autora portuguesa contemporânea, avolumam-se sensações, corpo, sensualidade, libido, leitura, poesia, drama, imagem, que se mesclam à figura de um escrevente que pulsa nas frases entrecortadas, nas palavras fulgurantes, nos fonemas insinuantes, nos vazios das páginas do livro.

O corpo textual transfunde líquido seminal que se espraia em ramificações de linguagem que concentram fios de onde se desprendem olhos, boca, nádegas, partes do corpo que se desarticulam para, em seguida, se rearticularem numa configuração outra, inusitada, resplandecente, luminosa nos novos entroncamentos que surgem ativando a constituição de um espaço escritural.

Nessa escrita encenada, corpo em movimento, não há lugar para a significação sob uma perspectiva convencional; o que se presencia, servindo-nos das palavras de Jean-Luc Nancy (2000, p.18), em seu livro Corpus, é "um gesto para tocar no sentido". Toque/tato/contato que dá origem a um novo corpo, "ser-excrito" (ibidem, p.20),"a escrita de um corpus enquanto partilha dos corpos, partilhando o

* Doutora em Letras pela Universidade de São Paulo(USP) e professora-assistente da Universidade Estadual Paulista (UNESP), campus de São José do Rio Preto. 
seu ser-corpo, mas não o significando, partilhada por ele, uma escrita separada portanto de si mesma e do seu sentido, excrita ao longo da sua inscrição" (ibidem, p.81-2). Corpo que se escreve com rupturas, descontinuidades, fraturas, desvios, fragmentos, faltas, ausências, ou, sob a perspectiva de Llansol (2000, p.31), corpo que se textualiza, corpo investido em sensualidade, escrita-corpo, "mais desprevenida, menos preocupada com o sentido e mais centrada no movimento".

É ainda nesse nível de reflexão que Nancy (2000) considera que não é possível tratar em separado corpo e pensamento, como se fossem totalmente independentes. Segundo Nancy (2000, p.36), "eles são apenas o seu mútuo tocar-se, o toque de efração de um pelo outro e de um no outro". Esse "mútuo tocar-se" é perceptível nesta sequência de Onde vais, drama-poesia?:

\section{[...]. O nosso}

pensamento sintoniza bem com o escuro,

o obscuro. O limiar do incompreensível, a sensação de que está próxima a fronteira onde acaba o humano, e soçobra a emoção (uma reduzida variedade de humano, vista a contraluz), a escrita, muito próxima da

, desfaz e contrapõe. (Llansol, 2000, p.32)

A escrita como corpo é penetrada pelo pensamento, que avança em profundidade tentando se impor, procurando talvez dominar, subjugar o corpo, mas este, munido da potência que o caracteriza, faz valer paralelamente o outro lado. No entrechoque, estabelece-se a solução: o corpo, ao sorver o pensamento, transveste-o, dissipando o equívoco e possibilitando o resvalar, o toque, o roçar. O não predomínio do pensamento é ainda configurado por meio de uma outra imagem em um dos cadernos manuscritos de Llansol, quando afirma que "o pensamento não coroa o corpo $\rightarrow$ é a sua estrada" (Espólio de Maria Gabriela Llansol, caderno 1.68, p.99).

Nessa equação corpo-pensamento, um outro termo se apresenta: "sexo", que, de acordo com Nancy (2000, p.37), "toca no intocável. É o nome-deflagrado do corpo, [...]". Sexo que assume, na obra de 
Llansol (2000, p.26), traços muito peculiares: ora é a "sensualidade do poema" que transparece, ora "O poema é sem tesão e pleno de desejo" (ibidem, p.18). Ora, ainda, de forma mais nitidamente corporal, "o seu poema deseja encostar a ponta do seio contra os botões da porta" (ibidem, p.29), imagem que alia uma manifestação da escrita (o poema) a uma parte singularmente erótica do corpo feminino (seio), entrelaçando, ainda, um pormenor associado à vestimenta (botões) a um objeto aparentemente inanimado (porta), mas que assume outra conformação devido à circunstância específica em que se faz presente; o poema, rompendo as barreiras, mostra-se, abre-se para o deleite do legente. E, aprofundando ainda mais o nível de corporificação, outras partes sensuais afloram:

Há uma sombra entre as nádegas, diz Hölderlin. Novo vocábulo. Onde havia ancas, surgem agora nádegas. Mas é a sombra entre elas que atrai o poema. (Llansol, 2000, p.35)

Na construção do poema, as palavras se avolumam, mas só serão aproveitadas as que, transpondo o nível imediato, penetram nas frestas e se transmutam, sobressaindo no conjunto, esgueirando-se, desviando-se do palpável, desafiando o estatismo dos vocábulos dispostos no dicionário e dotando-os de uma feição particularmente arisca, esquiva.

Dentro da mobilidade que o termo "sexo" assume na obra de Llansol (2000, p.44), ele é também associado à paisagem, vista como o "terceiro sexo", ao lado do homem e da mulher, ressaltando, nessa confluência, a poesia e a figura do poeta, na medida em que este tem a capacidade de deixar transparecer, segundo o escrevente de Onde vais, drama-poesia?, "a geografia imaterial por vir" (ibidem, p.45). O poeta, com sua percepção aguçada, transfigura a paisagem, mobiliza seus elementos constituintes, transforma o que é no que poderia ser, cria, enfim, uma "realidade" outra.

Ainda relacionado à palavra "sexo", mas, do outro lado, no ângulo da recepção, encontra-se o legente, incutido na composição 
de "sexo de ler", num gesto indicativo de determinação, de atitude ante o desconhecido, o surpreendente. Mais uma vez, corpo e pensamento concertados, num todo harmônico em que o ato de leitura é impulsionado pela força ativa inerente ao sexo, que, de sua parte, é acionado pela luz advinda do "luar libidinal", a que nos referiremos posteriormente.

$\mathrm{Na}$ correspondência do que se considerou em relação à escrita, a leitura, segundo Nancy (2000, p.85), não pode ser vista "como uma decifração, mas como o tocar e ser tocado, [...]. Escrever, ler, questão de tacto". O que implica um legente perceptivo, um legente que se embrenha no fluxo da escrita, que penetra nos interstícios da linguagem sem se limitar a chegar a um sentido. Um legente consciente de que, servindo-nos do texto de Llansol (2000, p.18), "ler é ser chamado a um combate, a um drama". Isso porque esse tipo de leitura requer uma interação do legente com o escrevente, um "duelo" que se trava no espaço textual onde pelejam as palavras que partem do escrevente rumo ao legente, que, por sua vez, absorve-as, propiciando que elas ressoem. Ou ainda, acompanhando as palavras da autora no caderno 1.71 (Espólio de Maria Gabriela Llansol, p.57), "legente é o que lê sabendo que existe outro modo de ler - mais próximo do texto - que penetra o texto e o torna, por sua vez, escrevente-". Ler é, portanto, estar num palco onde esses dois seres contracenam, se olham, se chocam, se embatem e se regozijam.

O legente é sugado por um universo literário que o leva a criar táticas de leitura, instigando-o continuamente a exercer seu poder de legência. É também seduzido por uma escrita-corpo povoada por figuras ("nós construtivos" do texto, nas palavras de Llansol), que, como notas de uma pauta musical que se movem ininterruptamente, agrupando-se, desagrupando-se e/ou reagrupando-se, dinamizam o texto. As figuras não apresentam contornos definidos, não têm identidade, abrem-se para o novo, para o insólito, afirmando-se apenas como entidades do texto, com a capacidade de pertencer a todos os tempos e lugares.

Na relação que se instaura entre o legente e a figura, são expressivas as intersecções estabelecidas em um outro caderno de Llansol: 
Quem deseja a Figura? O seu interlocutor em que ela transparece. No caso da escrita, o interlocutor é o legente - aquele em quem se expande as imagens constituídas pelo seu sexo de ler. As interrogações que o texto insinua, creio que é o seu material constitutivo. (Espólio de Maria Gabriela Llansol, caderno 1.66, p.123)

A figura metamórfica, tal como se apresenta na obra da escritora, é um desafio contínuo para o legente, que, imbuído de seu "sexo de ler", se arroja pelos meandros da escrita, um questionar permanente, não em busca de respostas, mas pela fruição que o texto propicia.

Nesse sentido, é instigante a figura da mulher, nomeada como “a mulher”, em Parasceve (Llansol, 2001), um ser híbrido, produto da relação simbiótica entre o humano, o animal e objetos, e que se transmuta na figura da mulher incorporada na árvore, o plátano, em Amigo e amiga - curso de silêncio de 2004 (Llansol, 2006, p.50):

sempre que o fotógrafo vem, depois de tentar várias posições, tira uma fotografia. Revela depois a figura apreensível do plátano, a mulher de braços abertos cujos ramos, principalmente dois, apontam setas para fora das margens; são perturbantes os rodeios do fotógrafo à volta do tronco, chove com placidez, e ele procura, para disparar o olhar da máquina, abrir uma brecha na secura. Por fim, a imagem torna-se fixa, e um desenho orientado para formas vulneráveis de mulher (híbrido de vegetal natureza) fica presente.

A congeminação mulher-árvore ultrapassa o que pode ser captado pela fotografia, rompendo o formato regular e avançando para além das margens. A coexistência integrada do humano e do vegetal impossibilita qualquer tentativa de caracterização isolada desse ser conjunto, a mulher-árvore, como também sua fixação ou enquadramento. É um corpo textual, circunscrito às ondulações da escrita, escrita que se movimenta sem cessar, construindo, ainda em Amigo e amiga - curso de silêncio de 2004, uma figura-mulher que sofreu uma perda e que busca conviver com a dor causada pela morte: 
E se, em vez de ser sempre designada por a mulher - a mulher decepada, a mulher da noite obscura, a mulher cortada cerce e até, com menor efeito de leitura, por a mulher cortada, lhe fosse oferecido o nome de estere - medida de volume para madeira ou lenha -, dado o seu incontornável bom senso celeste? (Llansol, 2006, p.128)

Esta sequência de nomes, a mulher decepada, a mulher da noite obscura, a mulher cortada cerce, indicia o diálogo vocabular que se estabelece em torno da mobilidade dessa figura, num processo de entrosamento com as palavras que chama a atenção para a variação de qualificações atribuídas à mulher e aos efeitos gerados, qualificações que envolvem um percurso de amputação a que se pretende resistir. Resistência gerada pela própria dor que, segundo Nancy (2000, p.48), "oferece uma evidência intensa, onde, longe de se tornar um 'objeto', o corpo que pena expõe-se absolutamente 'sujeito'”. Esse sujeito pleno, essa figura-mulher, agora nomeada pela escrevente como estere ou a lenha do silêncio (ibidem, p.223), caminha pelo texto e se alia não só ao silêncio, mas também à escrita e à leitura.

Inserida ainda nesse espaço textual, e relacionada ao silêncio gerado, distingue-se a figura de A. Nómada. Sentido como "presente ausente" (Llansol, 2006, p.157) pelo "eu”, Nómada perambula pelas páginas do livro tal como o próprio nome sugere, deslocamento já indicado pelos vocábulos "vagamundos" e "trilhador de mundos" trazidos na primeira página de Amigo e amiga - curso de silêncio de 2004. O que se tem sãoflashes dessa figura incapturável a deslizar entre as palavras que compõem o texto, como se pode observar na seguinte passagem:

Depois Nómada vem, e abre o piano, debruçado sobre o marfim do elefante, e a madeira do urso. Entra-se numa nova fase na caverna.

Agora, a musicalidade conduz a cúpula que,

penetrada de sons, voga sobre nós. (ibidem, p.63)

A ligação muito próxima de Nómada com o piano, já a partir das partes que constituem esse instrumento (o teclado e o arcabouço de madeira), interage com os sons que daí advêm, produzindo uma 
atmosfera esvanecente que envolve o "eu" e Nómada e nos remete à figura do homem nu ao piano em O jogo da liberdade da alma (Llansol, 2003, p.7), um híbrido de humano, vegetal e música: "O homem nu que toca tem músculos de música frontal, uma ramagem erótica por sexo, que desce dos ombros até ao teclado do piano".

Essa interação do corpo com o piano imprime ao texto de Llansol uma melodia muito particular, uma vez que não se trata de uma relação linear, unívoca entre escrita e música; cria-se uma simbiose entre o corpo erótico, que é também o corpo da escrita, e as notas que escorrem pelo teclado. Ambos emitem vibração, fazem soar um desejo pulsante que ecoa entre as palavras.

Esse desejo está incutido também no processo de construção do texto, tendo em vista que o escrevente a ele associa a expressão "luar libidinal”, energia transformável em libido, característica do corpo que se une à mente no momento da criação:

- Tenho um candieiro aceso de luz libidinal sobre o lugar onde estou a escrever [...]. Existir é um facto principal, e mergulho nele, até inundar-me de pura existência de luar libidinal. Não é sexo, não é temor de não ter sexo, é expansão de alegria pura [...]. Difundir os raios do corpo - é, m/ prazer e meu desejo. É o que desejo (É o que sinto ser luar libidinal). (Espólio de Maria Gabriela Llansol, caderno 1.54 , p.62-3 - grifo da autora)

Esse trecho encontra-se um tanto quanto modificado em Onde vais, drama-poesia? (Llansol, 2000, p.17-8), tendo passado por um percurso de transmutação em que novos elementos foram inseridos, ampliando, e complexando, os fios que aqui se dispõem. Um pouco mais elucidativo, dentro, é claro, do que é possível ser em terreno tão insondável e movediço, a sequência de frases do caderno manuscrito fornece alguns lampejos para a discussão sempre incitante do "luar libidinal". A tentativa não é de modo algum clarificar algo tão impalpável e escorregadio, mas apenas trazer à baila os vários componentes que se interceptam na constituição do "luar libidinal" e o distanciamento deles em relação à carga semântica com 
que foram convencionalmente fixados. É nesse sentido que termos como "corpo", "sexo", "libido”, "prazer", "desejo" adquirem outra conformação, sempre alargada, pois não passível de ser aprisionada em círculos restritos do significado. E é também nesse âmbito que, na continuidade de sua reflexão sobre "luar libidinal", Llansol emite as seguintes considerações:

Não tem nada a ver c/ nada, essa libido, nem definição do dicionário, nem Psicanálise, não é erotismo, nem sensualidade.

É essa palavra antecedida por uma outra - luar, q ilumina a cena.

Luar libidinal só por si mesmo se define (Espólio de Maria Gabriela Llansol, caderno 1.54, p.116, 118)

O que interessa, de fato, portanto, é que a "luz libidinal" incide sobre o escrevente, gerando um texto inquietante, palpitante, um texto que, além de se afastar do enquadramento a que as palavras são normalmente submetidas, atravessa as fronteiras dos gêneros literários, como se percebe, entre outras muitas manifestações em toda a obra de Llansol, explicitamente no título do livro Onde vais, drama-poesia?. O substantivo composto (drama-poesia) aí inserido aponta para a forma de realização do poema, que se faz enquanto corpo vibrante e fulgurado, desprendido de um "eu" ("poema sem-eu”, p.13, 14), confrontando, talvez, a concepção tradicional de gênero lírico. É a matéria viva atuando, poema que se encena, revigorando sua independência de construção, semelhante ao que se verifica nos textos com perfil narrativo, mas, ao mesmo tempo, afastados da narratividade, na medida em que avançam para o poético e para o dramático. Como diz João Barrento (2008, p.33), a obra de Llansol "é um Texto-entre-os-géneros (ou para além deles) [... ]".

Para além é que precisamos direcionar também o nosso olhar, deixando espaços sempre abertos para a infiltração da escrita e consequente espraiamento. Corpo febril, a escrita de Maria Gabriela Llansol lateja incessantemente, desacomodando o nosso foco de visão, fazendo-nos revirar as pupilas, atraiçoando-nos com seus 
movimentos periclitantes, sugando-nos aos bocados. Defrontamonos com um texto que exerce um fascínio perturbador, um texto que avança em direção ao legente, que o estimula a abrir a porta e adentrar no espaço prazeroso da linguagem, onde as palavras se deslocam em ritmo acelerado, desvestindo-se dos entraves da língua, ganhando elasticidade e vibrando como tons incandescentes. Incandescência necessária também na leitura a ser realizada de forma extensiva pelo legente, que precisa acompanhar os múltiplos veios e deixar-se levar pelo embalo dos sons, tropeçando nos desafios que vão surgindo, tentando ultrapassá-los e seguindo em frente, sabendo de antemão que outros se apresentam. Percurso acidentado, com muitos desvios e sem marco de chegada, pois o que importa é o caminho a transcorrer, é vaguear, é sentir-se oscilar, é balançar-se em fios muito tênues.

\section{Referências bibliográficas}

BARRENTO, J. Na dobra do mundo - escritos llansolianos. Lisboa: Mariposa Azual, 2008.

ESPÓLIO DE MARIA GABRIELA LLANSOL. Sintra. Cadernos 1.54, 1.66, 1.68, 1.71.

LLANSOL, M. G. Um falcão no punho. 2.ed. Lisboa: Relógio D’Água, 1998.

Onde vais, drama-poesia? Lisboa: Relógio D’Água, 2000.

. Parasceve. Lisboa: Relógio D’Água, 2001.

O jogo da liberdade da alma. Lisboa: Relógio D’Água, 2003.

Amigo e amiga - curso de silêncio 2004. Lisboa: Assírio \& Alvim, 2006.

NANCY, J.-L. Corpus. Lisboa: Vega, 2000. 


\section{3 \\ DA LITERATURA COMO ESPAÇO FOTOGRÁFICO-PICTÓRICO EM TEXTOS REESCRITOS DE DALTON TREVISAN}

Arnaldo Franco Junior*

Neste texto, abordaremos algumas das relações entre literatura, fotografia e artes plásticas na obra de Dalton Trevisan, procurando demonstrar que, no projeto literário e na escrita singulares do escritor, a literatura, desde o seu suporte primeiro - o espaço em branco da folha de papel - até a sua constituição como espaço plástico, é passível de ser concebida como imagem que remete à fotografia e/ou à pintura.

O trabalho de escrita de Trevisan se caracteriza, como demonstrou Rosse Marye Bernardi (1983), pelo recurso enfático à elipse, à atualização de signos e referentes e, na medida em que apoiado em uma contínua revisão e reescrita dos textos para a publicação de novas edições de seus livros, na repetição. Mariano Tôrres (1970), em texto de orelha da segunda edição revista e aumentada de $O$ vampiro de Curitiba, aborda o trabalho de escrita de Trevisan, advertindo

[...] o leitor que uma nova edição de Dalton Trevisan não significa apenas o relançamento de trabalhos seus. Esta advertência torna-se

* Doutor em Literatura Brasileira pela Universidade de São Paulo (USP) e professor-assistente da Universidade Estadual Paulista (UNESP), campus de São José do Rio Preto. 
necessária porque o contista curitibano tanto trabalha e retrabalha suas histórias, de edição para edição, que, na verdade, estas representam, do ângulo estilístico, novo livro. Embora as narrativas permaneçam as mesmas, enquanto enredo e estrutura, a fatura literária sofreu inúmeros retoques, foi burilada, esmerilhada, ganhou aqui uma palavra mais precisa, ali um vocábulo de maior impacto, adiante expressão que realça um diálogo, um comportamento, uma situação.

Hermilo Borba Filho (1974), em texto de orelha da terceira edição de Desastres do amor, já assinala a existência de uma tensão entre a narração, as histórias narradas e o material linguístico que as constitui na literatura de Trevisan:

Nele, o enredo é o de menos, importantes são as suas palavras aparentemente fáceis em estórias fáceis, mas ninguém se iluda: esta facilidade foi adquirida às custas de um infatigável trabalho de meditação, vivência, observação, numa espantosa recriação do cotidiano.

A existência de uma dissonância entre o refinado trabalho de escrita de Trevisan, caracterizado por economia e funcionalidade ${ }^{1}$ extremas que lhe permitem produzir textos cada vez mais condensados a cada nova versão de contos publicados, e a matéria linguística e referencial que privilegia em sua literatura (signos gastos, estereótipos, lugares-comuns, elementos e referências kitsch, roteiros previsíveis e repetitivos no plano do desenvolvimento da ação dramática - clichês,

1 Funcionalidade e economia são procedimentos-chave que caracterizam tanto a arquitetura moderna como algumas das artes plásticas das vanguardas modernistas na primeira metade do século XX. Veja-se, por exemplo, a produção arquitetônica da Bauhaus, que suprime radicalmente o elemento ornamental em favor de uma máxima funcionalidade, transparência e racionalidade na produção e no uso do espaço arquitetônico e, também, a supressão radical do dado figurativo no abstracionismo geométrico de Piet Mondrian e no suprematismo de Kasimir Malévitch. Pense-se, também, nos avisos e cartazes produzidos pelos construtivistas russos, que se constituem em uma das bases da pop art dos anos 50-60 do século XX. 
enfim) é um dado fundamental para o desenvolvimento de nossa hipótese de leitura.

O descompasso entre o trabalho de escrita caracterizado por um contínuo desbastamento dos signos ornamentais e/ou dispensáveis (em favor de uma máxima condensação da extensão e da tensão dramática do texto e da história narrada) e a trivialidade, digamos assim, do material linguístico selecionado para a composição dos textos literários, embora reconhecido por mais de um crítico da obra de Trevisan, foi, por vezes, lido como algo subordinado a um suposto realismo de feição neonaturalista que definiria a literatura do escritor. É nesse contexto de leitura que muitas das remissões à fotografia e à visualidade surgem na fortuna crítica de Trevisan. Observe-se, por exemplo, Mário da Silva Brito (1975a) em texto de orelha da quarta edição revista de Morte na praça:

Vejo-o como um restituidor excepcionalmente dotado. Em cada livro, em cada conto, ei-lo a recompor, por meio de palavras sabiamente escolhidas e sabiamente ordenadas, a realidade que o circunda, dela nos oferecendo, com apoio em pormenores acumulados, um fiel retrato, um retrato das coisas e das criaturas humanas.

É, aliás, nos pormenores que Dalton Trevisan mais trabalha. Para revelar os seus personagens em toda a inteireza. Descarna-os, invade-lhes a intimidade, desentranha suas escondidas frustrações, expõe-lhes os ressentimentos, mostrando-nos, todos eles, tal qual são. E para que sejam tal qual são, ilumina-os de implacável realismo. Um realismo que não dispensa, porém, sutis nuances, os claro-escuros que produzem reveladores relevos. [...]

Sob a aparência do fait-divers, do episódio corriqueiro, do acontecimento quotidiano, e, às vezes, até da anedota, Trevisan vê o drama das criaturas. O drama exibido a todos os olhos, mas nem sempre percebido. (grifos nossos)

E, também, Valdemar Cavalcanti (1979), que, em texto de orelha da quarta edição revista de Desastres do amor, valoriza, em Trevisan, a "posição de narrador singular, dotado de olho mecânico": 
O que impressiona em DT é sua capacidade de fixar a vida em flagrante, sem o mínimo retoque; o jeito peculiar de gravar, como a preto e branco, fatos e instantes, deixando nítidos os traços da fisionomia das pessoas, em transes de dor, desencanto ou desespero; a maneira personalíssima de enfocar um momento surpreendente ou uma situação inesperada dos seus Joões e Marias. Ele, sempre de olho na condição humana.

E DT faz isso, sempre, sem usar uma palavra a mais, coando as frases, olho atento na medida. Só cuidando do essencial e não dando vez ao que é puramente ornamental. (grifos nossos)

Poderíamos multiplicar os exemplos, na fortuna crítica, da metáfora que articula fotografia, realismo e escrita para caracterizar o trabalho e os efeitos da literatura de Dalton Trevisan, ${ }^{2}$ entretanto nosso objetivo é outro: demonstrar que essa leitura, embora pertinente, não esgota as possibilidades de interpretação das relações entre literatura e imagem, aqui tomada em sentido amplo, no texto trevisaniano.

Dada a ênfase progressivamente conferida ao mostrar, a narrativa de Dalton Trevisan aproxima-se da fotografia e de certos procedimentos (Chklovski, 1976) característicos de alguns importantes movimentos das artes plásticas de vanguarda, a saber: o abstracionismo geométrico, o suprematismo e a arte pop. Os vínculos com a fotografia evidenciam-se nos seguintes aspectos:

a) na ênfase documental conferida à linguagem que "adere" ao coloquial e, também, mimetiza o discurso característico do fait divers, ${ }^{3}$ simulando uma apresentação naturalista de "pedaços da vida" ao leitor;

2 Hermilo Borba Filho (1974) fala em "flashes de amores desastrados" para caracterizar os contos de Trevisan; Mário da Silva Brito (1975) afirma: "Ninguém, depois de lê-lo, gosta do mundo e da vida tal como a retrata - retrato que, infelizmente, corresponde a uma realidade concreta, palpável”; Jorge de Souza Araújo (1981) diz: "ninguém como Dalton para fotografar lances autofágicos da pequena burguesia submetida aos seus próprios ridículos”.

3 Segundo Barthes (2007, p.58-9): “o fait divers [...] é uma informação total [...] imanente; ele contém em si todo seu saber: não é preciso conhecer nada do 
b) na perspectiva de jogar com a criação de uma ilusão de identidade absoluta entre a coisa e a sua representação, procedimento marcado pelo confronto obsessivo de uma versão em processo de reescrita (e, portanto, partindo da coisa representada) com a versão pública tomada como a mais cristalizada ${ }^{4}$ (considerada como "a coisa em si" a ser, sempre, representada) - o que remete à reprodutibilidade técnica e à serialidade características da fotografia, que, a rigor, elimina, em seu campo de produção, a distinção entre original e cópia;

mundo para consumir um fait divers; ele não remete formalmente a nada além dele próprio; evidentemente, seu conteúdo não é estranho ao mundo: desastres, assassínios, raptos, agressões, acidentes, roubos, esquisitices, tudo isso remete ao homem, a sua história, a sua alienação, a seus fantasmas, a seus sonhos, a seus medos: uma ideologia e uma psicanálise do fait divers são possíveis; mas trata-se aí de um mundo cujo conhecimento é apenas intelectual, analítico, elaborado em segundo grau por aquele que fala do fait divers, não por aquele que o consome; no nível da leitura, tudo é dado num fait divers; suas circunstâncias, suas causas, seu passado, seu desenlace sem duração e sem contexto, ele constitui um ser imediato, total, que não remete, pelo menos formalmente, a nada de implícito; é nisso que ele se aparenta com a novela e o conto".

4 Neste trabalho, versão pública mais cristalizada é aquela que, embora nunca realizada publicamente sob forma documentada, é pública porque codificada em função de sua repetibilidade. No entanto, embora a versão pública mais cristalizada pertença ao imaginário reificado do senso comum, caracterizado, em geral, pela linguagem estereotipada, ela não assume uma forma única. Sua "singularidade" provém de sua mesmidade, isto é, do fato de se constituir em diferentes formas de dizer o mesmo. Explorá-la no processo de produção de uma nova versão datada e autoral - sempre a última que está sendo escrita-é explorar seu ponto de inflexão, situado no cruzamento entre a repetibilidade de seus sentidos com o caráter fugidio dos eventos históricos em que ocorre. Reificada e estereotípica, a versão pública codificada é, portanto, pública tanto do ponto de vista do seu pertencimento comum - é coletiva e anônima - quanto do ponto de vista da sua abertura à apropriação individual - oferece-se a qualquer pessoa - pelo autor e pelo leitor. Com essa ideia, não pensamos em enunciados colhidos, necessariamente, de fato, pelo escritor, mas na busca de representação de um imaginário petrificado sob as formas de dizer do senso comum. Em termos de sua utilização como matéria de criação, seu caráter público, ainda que despojado de um suporte definido, isto é, ainda que não realizado sob forma documentável, garante, portanto, que seja, ainda assim, identificada e reconhecida pelo leitor. 
c) no sentido criado pela repetição, que, afetando as histórias recontadas em cada nova versão de um mesmo conto, espectraliza-as, fazendo delas, considerada a relação entre as várias versões e o plano metalinguístico inerente ao modo de produção trevisaniano, literatura feita, antes de tudo, de literatura;

d) no processo de singularização produzido pela radical despersonalização a que o escritor submete as personagens, suas ações e as fábulas que compõem a sua história - processo intimamente vinculado ao jogo com a inter e a intratextualidade que, na obra, desconstroem a ilusão naturalista que caracteriza a apresentação do "pedaço de vida" para melhor revelá-la como simulacro.

O traço fundamental que une o trabalho de Trevisan à fotografia é a natureza fantasmática da imagem/do referente presente em ambos. Tal como a imagem fotografada congela o tempo e espectraliza o referente, criando a ilusão de uma representação maximamente realista, os textos revisados, reescritos e condensados do escritor, ao articularem, em sua produção, a elipse e a repetição, afirmam, no produto final de cada "nova" produção, referentes congelados cuja substância espectral simula a ilusão de literatura-verdade. ${ }^{5} \mathrm{Se}$, sentido criado pela repetição que rege a elipse, tudo muda para permanecer sempre igual, as diversas versões de cada conto criam a ilusão de movimento e, por extensão, de mudança, para melhor negá-las.

5 Segundo José Paulo Paes (1984), “erraria quem visse no realismo sem mais nada de Dalton Trevisan um bisturi de cirurgião ou [...] uma faca de açougueiro que tivesse o seu poder de corte de todo embotado por causa do uso excessivo ao longo destes cem anos que nos separam de Maupassant. Poucas vezes foi a carne da vida cortada mais fundo, poucas vezes foram as suas vísceras e ossos expostos à vista do respeitável público com igual impiedade. E, paradoxalmente, esse feroz realismo acaba por infundir no leitor uma sensação de irrealidade, de ilogicidade, simbólica (ou alegórica ou metafísica ou que outro nome possa ter), a qual não chega, porém, a configurar-se como intenção. Não é difícil ver para onde aponta essa simbólica involuntária: para o absurdo da vida, para a inanidade de querer descobrir-lhe um sentido ou impor-lhe outro fim que não seja o de simplesmente vivê-la". 
Dalton Trevisan, como demonstra Bernardi (1983), atualiza os referentes que poderiam, por anacrônicos, datar os seus contos e o seu trabalho. Tal preocupação com a atualização e/ou a supressão de tais referentes, de modo a eliminar os aspectos de historicidade que os tornariam opacos para o lector universalis projetado no horizonte de expectativa de sua obra, visa, por um lado, garantir a legibilidade do texto pelas novas gerações, mas, por outro, mimetiza - não sem ironia - a permanente renovação da mercadoria característica do contexto de produção e consumo típicos da era industrial. Esse procedimento de contínua reescrita busca construir, sob o modelo de uma versão pública tomada como a mais cristalizada do fato em si, uma problematização da tensão entre os modos de produção característicos do artesanato e da indústria no que se refere à reflexão sobre a arte e o artista no mundo contemporâneo e na sociedade de consumo. Tal tensão, explorada no trabalho do escritor, discute as concepções modernas de autor, autoria, arte, originalidade, novo conceitos caros à arte e à cultura ocidentais desde o romantismo. ${ }^{6}$

A atualização de referentes e da linguagem instala, nos contos, uma simultânea afirmação e negação do apuro documental da literatura de Dalton Trevisan. Afirmação, na medida em que dá o testemunho, no/do fluxo de objetos e de homens-coisa, de um

6 Pode-se dizer que o termo romantismo abriga um conjunto de manifestações estéticas que inauguram o conceito moderno de autoria e, com ele, os paradigmas de criação e crítica que caracterizarão a produção e a recepção de arte na cultura ocidental. Ver, a respeito, Abrams (1962) e Paz (1984). De modo análogo, podese dizer que modernismo é um termo que serve para conferir identidade a um conjunto heterogêneo de proposições estéticas vigentes entre 1850-1860 e a primeira metade do século XX, cujo traço comum foi a radicalização da herança romântica que reivindicava total autonomia quanto à experimentação e à criação de valores, modos de composição e de expressão avessos às artes acadêmica e burguesa. Tal radicalização consolidou-se na expressão das artes de vanguarda, que projetam o ideal de uma arte que rompe radicalmente com o passado e, desprezando os valores da tradição, antecipa-se ao futuro, inaugurando, no presente, o novo, o original, o inédito, o moderno, a autenticidade de um estilo único (um modo de construir, elaborar, expressar, perceber, sentir, viver etc.), rompendo com a alienação da arte pela arte, com o anacronismo das academias, com a separação burguesa entre a arte e a vida. 
passar do tempo. Negação, na medida em que dá o testemunho de uma permanência dos mesmos valores-ações e de uma estrutura ironicamente "ontológica" humana que é impermeável à ação e à passagem do tempo.

A atualização, portanto, presentifica, na obra de Trevisan, o Mesmo sob o signo da diferença por meio de um procedimento que cria o diferente atual ao tomar como parâmetro a busca obsessiva da mesmidade de suas versões públicas tomadas como as mais cristalizadas. ${ }^{7}$ Nesse sentido, lidas diacronicamente, ${ }^{8}$ as diversas versões de um mesmo conto testemunham fotograficamente o fluxo de um tempo que não muda a não ser nas ações de linguagem pertinentes à intriga e que não promove transformações a não ser no leitor, ao reconhecer-se como parte dela e surpreender-se opinando sobre a moldura que o inclui. Vejamos um breve exemplo:

No almôço, João chamou a atenção da noiva que falava a um convidado, agora era dona casada e não podia conversar com qualquer homem.

7 Nízia Villaça (1984, p.53-4) afirma: “Toda a obra de Dalton Trevisan é uma reflexão sobre o senso comum. Senso comum como ideologia em seus níveis mais baixos, como acumulação de conhecimentos populares e das maneiras de ocupar-se com a vida cotidiana [...]. Dentro do próprio senso comum, as contradições entre as maneiras de pensar permanecem e se manifestam entre idéias tomadas das ideologias dominantes e as espontâneas, geradas através da experiência [...]. A ideologia do senso comum é [...] apontada e de certa forma desmitificada. Apesar da aparente transparência com que [são estruturadas as] narrativas, assistimos à desconstrução de um universo mítico pela superposição de várias ideologias: a que preside o mundo narrado, a do autor que a retoma e exacerba e a do leitor que também falará de um lugar ideológico. Da interação destas vozes nasce o texto, não redutível a nenhuma delas, e morre o mito".

8 Observe-se que estabelecemos uma distinção entre a nossa perspectiva de leitura e sua correspondente metodologia de trabalho e o trabalho de criação de Trevisan. Quando reescreve, Trevisan trabalha com a última versão publicada do texto, submetendo-a ao seu processo particular de escrita, do qual resultará um novo texto. No horizonte desse processo é que está a versão pública mais cristalizada - matéria para a atualização da linguagem e para a aplicação da elipse. Em nossa proposta de leitura, comparamos versões já prontas e publicadas entre as quais a versão pública mais cristalizada se dá a ver. 
Desde a repreensão, não mais a olhou nem lhe dirigiu a palavra, a não ser na presença de terceiro. Mais tarde ralhou com ela por despedir-se em lágrimas da mãe viúva: era como se não o quisesse acompanhar na lua-de-mel.

Na primeira noite a noiva se arrependeu de ter casado, pois êle a acusou de não ser virgem. Ela jurou, de mãos postas, que era filha de Maria e a mais pura das moças. [...]

Instalados na casa, brigava com ela todos os dias; proibia-a de fazer qualquer visita à sogra e de ir no domingo à missa, pois mulher sua não andava sozinha pela rua. Quase a esganou ao dar com a môça na janela da sala, espanador na mão e lenço vermelho na cabeça.

Êle foi para o emprego, Maria arrumou a trouxa e deixou um bilhete sôbre o travesseiro:

"Querido João, você judiou demais de mim. Não tenho mais amor, embora ache você um homem trabalhador. Pensava que ia ser feliz e foi tudo ilusão. É melhor que eu me separe de você fugindo escondida pois na sua frente eu não teria coragem. Vou para um lugar onde não possa me encontrar. Não faça nenhuma bobagem. Adeus para nunca mais."

João foi à casa da sogra e arrependeu-se diante da mãe e da filha. Desculpou-se das placas azuis na coxa bem branca de Maria e não era só: ela tinha o pescoço todo arranhado. Reconheceu por essa luz que o alumiava que era môça muito virgem. Nunca mais iria impedir-lhe que chegasse à janela da sala. Nem obrigá-la a sentar-se de costas para os outros.

Condoída e, além do mais, grávida, a moça - ai dela - voltou para casa. Assim viveram seis anos, ora em idílio (nasceu uma filha), ora em guerra (outro filho teve poucos dias de vida com as surras que ela sofreu durante a gravidez). A princípio João não batia sem discutir, depois ela apanhava sem conversa mesmo. Bêbado era ainda pior: pontapé no cachorro, beliscão na filha, sova de cinta na coitada da môça. (Trevisan, 1970, p.25-7) 
No almoço, João chamou a atenção da noiva que falava a um convidado, agora era dona casada e não podia conversar com qualquer homem.

Desde a repreensão, não mais a olhou nem lhe dirigiu a palavra, a não ser na presença de terceiro. Mais tarde ralhou com ela por despedir-se em lágrimas da mãe viúva: era como se assim não o quisesse acompanhar na lua-de-mel.

Na primeira noite a noiva muito se arrependeu de ter casado, pois êle a acusou acusada de não ser virgem. Ela jurou, de mãos postas, jurou que era filha de Maria e a mais pura das moças. [...]

Instalados na casa, brigava com ela todos os dias; proibia-a de fazer qualquer visitar a sogra e de ir no domingo à missa, pois mulher sua não andava sozinha pela rua. Quase a esganou ao dar com a moça na janela da sala, espanador na mão e lenço vermelho na cabeça.

Ele foi para o emprego, Maria arrumou a trouxa e deixou um bilhete sobre o travesseiro:

"Querido João, você me judiou demais de mim. Não tenho mais amor, embora ache você um homem trabalhador. Pensava que ia ser feliz e foi tudo ilusão. É melhor que eu me separe de você fugindo escondida, pois na sua frente eu não teria coragem. Vou para um lugar onde não possa me encontrar. Não faça nenhuma bobagem. Adeus para nunca mais".

João foi à casa da sogra, e arrependeu-se diante da mãe e da filha. Desculpou-se das placas azuis na coxa branquinha de Maria e não era só: ela tinha o pescoço todo arranhado Quem lhe arranhara todo o pescoço? Reconheceu por essa luz que o alumiava que era moça muito virgem. Nunca mais iria impedir the que chegasse à janela da sala. Nem obrigá-la a obrigar a sentar-se de costas para os outros

Condoída e, além do mais. Grávida, a moça - ai dela - voltou para casa. Assim viveram seis anos, ora em idílio (nasceu uma filha), ora em guerra (outro filho teve poucos dias de vida com as surras que ela sofreu durante a gravidez). A princípio João não batia sem discutir, 
depois ela apanhava sem conversa mesmo. Bêbado era ainda pior: pontapé no cachorro, beliscão na filha, sova de cinta na coitada da moça. (Trevisan, 1975, p.19-21)

No exemplo, os trechos grifados em vermelho indicam as supressões e os trechos grifados em amarelo indicam os acréscimos e as alterações. Observe-se que o recurso à elipse produz uma condensação do texto e, também, que a repetição é efeito do trabalho de reescrita e republicação. Longe de serem simples procedimentos de edição, a elipse e a repetição atuam sobre o excedente do que se supõe como a versão pública mais cristalizada sobre um dado fato. Esse trabalho com o já dito, representado por essa versão pública modelar, opera, no entanto, segundo dois movimentos. Por um lado, busca identificar, nela, o lugar-comum e o estereótipo, mas, por outro, está submetido ao imponderável das diferentes formas de dizer o mesmo, razão pela qual, na produção de uma nova versão, há sempre o que alterar na versão um dia considerada definitiva.

Considerado o trabalho de revisão e reescrita, a obra de Trevisan afirma-se como work in progress e, nesse sentido, é passível de aproximação com o abstracionismo geométrico e o suprematismo, porque se pauta estruturalmente por alguns dos procedimentos característicos de tais escolas (supressão do ornamental e do acessório, combinatória de signos reduzidos à funcionalidade). Seu vínculo maior, entretanto, é, de nossa perspectiva, com a arte pop, dado o interesse na apropriação de signos degradados, consumidos, serializados, kitsch (o dado excessivo retorna, pois, como citação, signo de signo, informação serializada e sem origem). Ainda que por efeito de associação, a reescrita trevisaniana faz do papel em branco uma tela na qual os signos degradados que constituem as paixões de homens anônimos da massa urbana compõem a matéria linguística previsível a partir da qual, considerada a imponderabilidade das diferentes formas de dizer o mesmo, são criadas imagens sempre novas do mesmo.

É a partir de tal prisma de leitura que os signos degradados e o kitsch -índices de uma profunda reificação, sejam eles as referências 
mais evidentes de mau gosto ou os elementos e as estruturas que caracterizam um kitsch insuspeito -, dá-se a ver como fluxo petrificado do tempo, signo paradoxal de um tempo sem passado nem futuro e de um espaço sem tridimensionalidade. Tais elementos são, pois, na obra continuamente reescrita, o signo de uma circulação imóvel e ininterrupta em que nada muda e que é, ela mesma, impotente para produzir a mudança.

Segundo Berta Waldman (1977, p.252),

Quando D.T. elege o vampirismo como matéria, elege a seriação, a repetição, a tautologia. Mas ele não se propõe a falar de vampiros, mas a falar vampiros, isto é, utilizar (ainda que num certo plano) uma linguagem-objeto e não a metalinguagem, por isso cria, no nível formal, um produto análogo à matéria de que parte. [...]

Essa forma de representação em que linguagem e coisa se confundem não remete a uma tradição que pretende fugir do ilusionismo e, em vez da ilusão do objeto, fornecer seu próprio elemento? Com o Impressionismo introduz-se esse procedimento: em vez da imagem da totalidade, os materiais de que se compõe a experiência.

Faremos, aqui, um pequeno adendo às pertinentes considerações de Waldman: o impressionismo supervaloriza um elemento que a obra de Trevisan, embora o utilize no trabalho de esculpir os textos por meio da elipse, nega: o movimento. No impressionismo, o movimento atesta a precariedade do que parece fixo, revelando a fixidez como uma ilusão de ótica; na obra de Trevisan, dá-se o contrário: o movimento só é evidente nas alterações existentes entre cada uma das versões de um mesmo conto, o que contribui para atestar a precariedade da obra acabada e a imprevisibilidade do sentido, mesmo do mais repetível. Quando se toma, porém, uma única versão, tanto no plano da história narrada como no plano da narração, Trevisan afirma a fixidez não como ilusão de ótica mas como repetição infinita, captável no lugar-comum e no estereótipo, ligada à versão pública tomada como a mais cristalizada. 
Assis Brasil (1972) associa o trabalho de Dalton Trevisan à pintura neoplasticista de Piet Mondrian. ${ }^{9}$ Avaliando, em texto de orelha, as histórias de João e Maria presentes em A guerra conjugal, Brasil (1972, p.264), além de valorizar a opção faulkneriana do narrador dos contos pela contenção máxima das marcas de sua própria subjetividade na enunciação, estabelece uma relação entre os trabalhos de Trevisan e Mondrian que vale a pena observar:

Como já nos referimos, neste livro [A guerra conjugal] Dalton Trevisan atinge o mito em sua ficção, coisa raríssima na literatura brasileira. Seus personagens, João e Maria, são agora a suma criativa da sua arte. [...]

João e Maria não são mais os modestos nomes de alguns personagens às voltas com seus problemas e aberrações: João e Maria são agora parte importante de uma "mitologia" daltoniana, de um modo de ser da vida, num mundo que já não está ligado às contingências históricas. Desde as Novelas nada exemplares que já havíamos assinalado a coerência criativa de Dalton Trevisan, em busca de uma expressão reflexiva do gênero humano. E ele atinge a depuração total, qual um Mondrian e sua tela em branco.

A associação de Trevisan com Mondrian é interessante porque, em certo sentido, pode-se reconhecer, na poética do escritor curitibano, uma série de procedimentos estruturalmente comuns à poética do pintor holandês. Pode-se, nelas, por exemplo, identificar o traço construtivista que professa uma "crença platônica no aperfeiçoamento da forma" (Golding, 1991, p.53). Além disso, as personagens, as ações, as intrigas, o padrão estilístico das frases e dos períodos, as imagens, as figuras de linguagem, as expressões características das falas das personagens e da voz do narrador são,

9 Berta Waldman (1977) faz uma referência ao vínculo entre alguns dos procedimentos característicos da poética trevisaniana e aqueles característicos dos abstracionistas do início do século ao nomear um dos capítulos de Do vampiro ao cafajeste com uma referência ao famoso Quadrado branco sobre fundo branco, do suprematista Kasimir Malevitch. 
na reescrita trevisaniana, passíveis de redução à condição elementar que caracteriza a cor, a forma geométrica, a linha em Mondrian. No entanto, as semelhanças param por aí. Não há no trabalho de Trevisan projeção da utopia modernista que, animada com o futuro e, portanto, francamente teleológica, caracterizou o trabalho de Mondrian. Os procedimentos, embora aproximáveis estruturalmente, produzem sentidos distintos: em Trevisan, a positivização do futuro cede lugar à afirmação desencantada de um irônico eterno retorno, tempo de um presente imóvel e, no plano fabular, avesso às ideias de transformação, mudança, originalidade, invenção, novo.

A natureza dos elementos fundamentais que caracterizam o repertório a partir do qual Trevisan e Mondrian criam é, na verdade, marcada por uma distinção fundamental: Mondrian chegou à proposição de uma poética que reduz a pintura à articulação de linhas e formas geométricas marcadas pelas cores primárias puras baseado em um ideário metafísico que concebe tais elementos como essências puras, projetando-os para um futuro de esperança $a^{10}$ a ser criado pela ciência moderna; ${ }^{11}$ a poética de Trevisan reduz a criação literária à articulação de um mesmo conjunto de elementos que, marcados pela repetição, negam qualquer ideário metafísico e qualquer utopia de futuro. Além disso, a poética trevisaniana não concebe tais elementos mínimos como encarnação de essências puras; ao contrário: insiste em apontá-los como a negação da própria ideia de essência, já que sua condição é a de um simulacro multiplicado ao infinito que, desprovido de origem, continua a reproduzir-se infinitamente. Isso tanto

10 Segundo Charles Harrison (1991, p.143): “A abstração do começo do século XX - a de Kandinsky, Malevitch e Mondrian - tinha sido sustentada pelo idealismo e pela crença 'no advento de uma era de grande espiritualidade",. Herbert Read (1972, p.87) confirma: "no caso de Mondrian [a filosofia construtivista] possuía implicações místicas derivadas da teosofia”.

11 As palavras de Herbert Read (1972, p.87) sobre o construtivismo evidenciam a pletora utópica característica do modernismo do qual participa Mondrian: "Os construtivistas usavam a palavra 'realidade' para descrever seus ideais, mas queriam indicar por meio disto que sua meta era a criação de uma nova realidade, o produto de uma atividade que usa apenas os elementos absolutos de espaço e tempo". 
no plano das fábulas quanto no plano da narração. Neste último, o trabalho de edição feito por Trevisan reformula, insistentemente, por meio de variados tipos de intervenção linguística, os momentos em que o narrador desponta e destoa de um certo tipo de apropriação da fala do outro. Alguém poderia dizer que tal busca é a de uma apropriação naturalista da voz do outro. No entanto, seu naturalismo não se dá em relação aos fatos ou às pessoas do mundo, mas a fatos de linguagem. É, sempre, com o olho no já dito de uma versão pública tomada como a mais cristalizada que o autor realiza seu trabalho de edição, feito de modo que o destinatário/leitor se plasme nas vozes da ação dramática, como se o próprio conto assumisse o leme do desenvolvimento da fábula. É, pois, distraindo-se com a naturalização dos dizeres que o leitor é surpreendido como parte da ventriloquia que assola personagens como os inúmeros joões e marias do escritor.

O novo é o signo a partir do qual Mondrian cria e projeta a sua obra; no caso de Trevisan, o novo é um signo problematizado, paradoxalmente afirmado pelo recurso a elementos e procedimentos que, se não o negam, sabotam consideravelmente a sua possível utopia. Analisando a dialética da vanguarda, Eduardo Subirats (1987, p.61) evidencia o laço que une, no contexto de expressão e afirmação das vanguardas modernistas, o racionalismo cartesiano com a projeção de um futuro utópico ao qual não é avessa a ideia de espiritualidade:

[...] a filosofia cartesiana privilegia aquelas formas do conhecimento, como a geometria e as matemáticas, assentadas sobre uma base lógica, cuja validez é autônoma e absoluta. Tal oposição intelectualista caracteriza-se de maneira análoga às mais influentes teses teóricas e programáticas do período heróico das vanguardas artísticas. Um dos exemplos mais característicos a este respeito é oferecido, no romantismo estético do expressionismo alemão, pela defesa arquitetônica e pictórica do cristalino. A estética do cristal, que é afim também ao purismo, ao cubismo e à art déco, parte, implícita ou explicitamente, da concepção idealista dos sólidos platônicos, quer dizer, de uma ordem geométrica e ideal comum ao espírito e à natureza. Este idealismo de signo espiritualista, tão brilhantemente exposto por teóricos 
da pintura moderna como Kandinsky ou Klee, coincidiu por outro lado com os valores científicos ou racionalistas através dos quais a arte das vanguardas ou uma parte dela presumia uma síntese com a civilização técnico-científica.

Não é difícil reconhecer, a partir dessas considerações, que o novo que caracteriza o projeto e o horizonte sociocultural e político de criação de Mondrian está assentado numa concepção teleológica de tempo e de história, livre do desencanto e da desconfiança permanentes que, a partir do pós-guerra, instalam-se no mundo contemporâneo.

O novo que caracteriza o projeto e o horizonte sociocultural e político de criação de Trevisan emerge de modo paradoxal, afirmando-se de modo ambíguo e irônico em relação à herança moderna/modernista; desconfiado, talvez por força, também, de uma aguda percepção da condição de país periférico e subdesenvolvido que o Brasil ocupa no contexto capitalista e na cultura ocidental. Não é à toa que a contística trevisaniana insiste na pontuação de referências que evidenciam a degradação material e espiritual de suas personagens. Se, por força da repetição e da especularidade, as personagens espectralizam-se, não perdem, paradoxalmente, os atributos que nos permitem identificálas como pertencentes às classes pobres e remediadas da população que ocupa, numerosa, as enormes faixas periféricas e suburbanas intrinsecamente ligadas à criação e à manutenção das grandes cidades criadas na era industrial. Cidades que, no Brasil, desenvolveramse, sobretudo, a partir dos anos 50 do século XX, com as políticas desenvolvimentistas iniciadas no governo de Juscelino Kubitschek.

Estabelecendo uma relação entre a produção literária de Dalton Trevisan e o contexto sócio-histórico brasileiro dos anos 40-60 do século XX, período em que ela surge e se afirma, Álvaro Cardoso Gomes e Carlos A. Vechi (1981, p.95) afirmam:

[...] a matéria humana abordada por Dalton Trevisan só aparentemente se afasta de nosso panorama histórico-social. Embora préindustrial, a realidade fixada pelo contista paranaense se revela uma mitologia semelhante à da década de 60. Dalton mostra-nos o retrato 
de uma classe cuja aspiração máxima sempre foi ver o indivíduo preso a um ideal ufanístico. Justamente por isto, esta classe é a responsável pela manutenção de uma história que sempre se definiu hierarquicamente - tudo o que se faz leva em conta a conservação de privilégios, com a conseqüente marginalização dos menos favorecidos.

Não é difícil, portanto, observar que a ficção de Dalton, um retrato das décadas de 40 e 50, é um painel que prevê as décadas de 60,70 e 80 ; isto porque o provincianismo de suas personagens reflete um período que antecede a industrialização propriamente dita. $\mathrm{O}$ sonho do país grande, um mito coletivo que vem desde Caminha, já se havia corporificado numa sociedade em que o avanço industrial ainda não era efetivo. Em outras palavras, tal crença estava esperando o momento oportuno para eclodir. Eé justamente a partir do governo Kubitschek que se criam condições favoráveis para a sua eclosão.

Em que pese a pertinência de tais observações, o que nos interessa, aqui, sublinhar é o fato de que as linhas mestras que caracterizam o modus faciendi do projeto literário de Trevisan apresentam um caráter industrial já na década de 1950, ou, se quisermos ser mais precisos a partir das informações de Bernardi (1983) relativas à atividade do escritor na revista Joaquim, já na segunda metade dos anos 1940. Esse caráter fabril mimetiza, de modo ambiguamente irônico, a própria euforia desenvolvimentista implantada no Brasil a partir dos anos JK. De caráter alegórico, tal mímese é irônica porque instala uma tensão crítica entre o modo de produção do texto e os signos e referentes que constituem sua história narrada, francamente pré-industriais e marcados pela degradação. Trata-se, talvez, de um modo de comentar os efeitos perversos da modernização autoritária que, no Brasil, não promoveu uma democratização capaz de emancipar o homem e criar uma sociedade efetivamente moderna, democrática e civilizada, mas, ao contrário, reforça, nesse e na sociedade, o aprisionamento ao autoritarismo e à barbárie.

Em outra interessante aproximação com as artes plásticas de vanguarda, Berta Waldman (1977, p.254) identifica o trabalho de Dalton Trevisan à pop art: 
D.T. não está sozinho em sua proposta estética (anestética?). Poderíamos filiar sua obra à Pop Art. Esta também rouba uma linguagem - a imagem comum fabricada pelos meios de comunicação de massas -, também nos fornece a repetição e realiza uma obra dentro de um idioma propositalmente descuidado que requer a habilidade de, trabalhando com os recursos da linguagem e da paisagem da cultura popular, mostrar, num espelho capaz de aumentar a imagem refletida como uma insistência de um super modulado vídeo comercial, a paisagem da máquina e seus derivados.

O espaço arte/vida reduz-se e a Pop Art trabalha em torno da ironia em que nos vemos lançados de estarmos vivendo ilusões, istoé, a mitologia, que nos é dada pelos veículos de comunicação de massas, em que viver é sempre viver em segundo grau. [...]

$\mathrm{Na}$ fragmentação da figura Pop e em sua repetição como na fragmentação e repetição das narrativas de D.T. não está a representação metonímica da realidade, mas a metáfora de uma realidade que se reduz à compartimentação.

Divergimos de Waldman no tocante à possibilidade de uma leitura alegórica dos contos-fragmento de Trevisan. Considerado o trabalho do escritor como obra em progresso e, também, os sentidos nele criados pela repetição, é possível, também, reconhecer cada conto como sinédoque que alegoriza o todo para o qual se volta. Eis o que pretendemos demonstrar a seguir, efetuando uma análise das homologias estruturais existentes entre o trabalho do escritor curitibano e João e Maria, tela pop do artista plástico Rubens Gerchman (1989). João e Maria é uma tela feita por Gerchman em 1974. É interessante compará-la aos contos de Dalton Trevisan que têm exatamente por heróis do inferno doméstico os joões e que, embora variem as suas posições na sintaxe inflexível, repetitiva e previsível que rege as relações homem-mulher no universo trevisaniano, são passíveis de redução a uma única unidade espectral que se projeta ao infinito, anulando a concepção linear de tempo em favor de uma concepção marcada pelo retorno do mesmo. Nossa leitura comparativa visa, também, demonstrar como a literatura de Trevisan já antecipava 
procedimentos e valores que, mais tarde, comporiam, guardadas as devidas proporções, o universo artístico característico da efervescência pop de alguns dos movimentos e das expressões culturais dos anos 1960-1970 no Brasil.

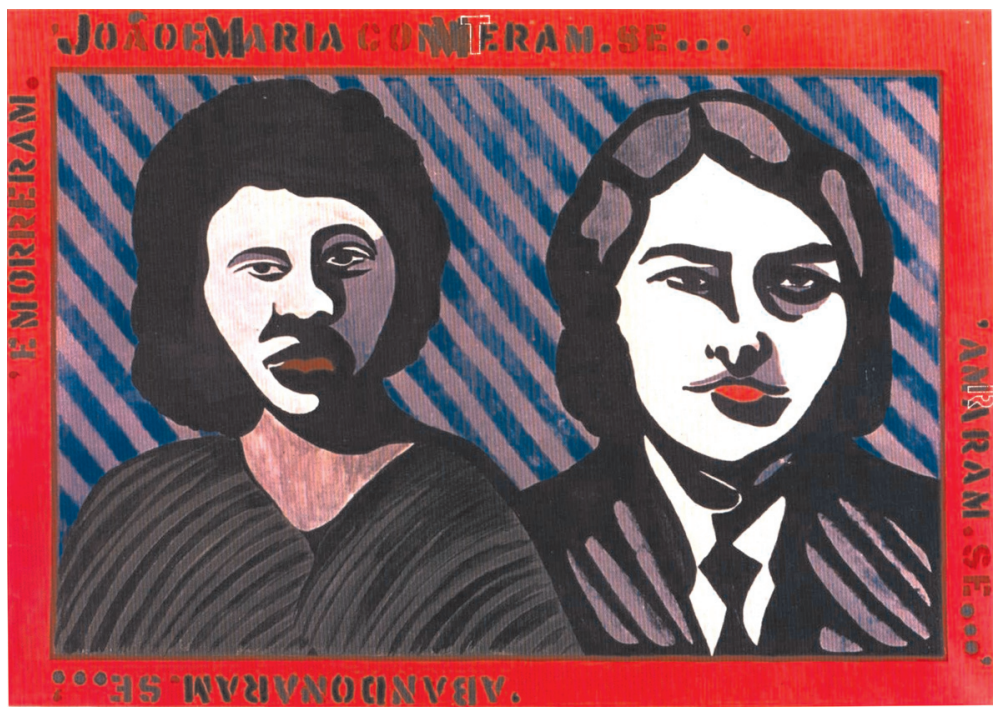

João e Maria, de Rubens Gerchman, é uma tela que remete àquelas antigas fotografias pintadas ${ }^{12}$ de casal que, após o casamento, eram expostas na parede da sala de modo a registrar, não sem alguma redundância, a união dos amantes. Signo de distinção social no início do século XX, quando a fotografia começava a se popularizar no país,

12 A técnica da pintura de retratos fotográficos foi, originalmente, desenvolvida para dar cor a fotografias em preto e branco e, também, para reconstituir e/ou modificar a natureza das imagens: "restaurar" um rosto ou detalhe apagado, mutilado ou perdido ou, também, alterá-los, aproximando-os não da realidade, mas das fantasias daquele que encomenda o trabalho. No caso das fotos de família, mercado preferencial desse tipo de trabalho, o retrato fotográfico pintado resulta de uma operação que sobrepõe a ficção às limitações do registro fotográfico do real: à mão do fotógrafo-pintor cabe a tarefa de satisfazer o cliente, concretizando em trompe l'oeil "realista" o que não passa de idealização. 
tais fotografias, a partir dos anos 1940, disseminaram-se nas casas brasileiras, sobretudo as das classes média e baixa. Isso, pelo menos até os anos 1950-1960, quando caíram em desuso nas casas de classe média e passaram a ser identificadas como elemento característico da decoração das casas da gente pobre e/ou suburbana.

Coloridas à mão, mesmo após a popularização da fotografia em cores, tais imagens afirmam-se como uma espécie de selo que reitera, para o espectador, a união amorosa e civil dos amantes que, fotografados do busto para cima e postados lado a lado, olham diretamente para o espectador. Particularmente quando coloridas à mão, tais fotografias, não raro emolduradas com requinte e colocadas estrategicamente na sala e/ou no quarto de dormir do casal, edulcoram e idealizam o casamento e a união amorosa, funcionando simultaneamente como "registro" do que eles são e como afirmação e/ou lembrança do que eles deveriam ser. Tais fotografias têm, portanto, o apelo das canecas de florinha ou coração gravadas com as palavras aMOR ou FE $\mathcal{M}$ CTDADES em letras vermelhas e/ou douradas.

Efeito involuntário ou não, o caráter documental da fotografia é, nesse caso, evocado e negado ao mesmo tempo. A imagem gravada é, simultaneamente, real e irreal, registro documental e projeção fantasiosa. É exatamente a diluição de tais fronteiras o que ela sedutoramente oferece aos fotografados e aos demais espectadores. Tais fotografias são, para usarmos os termos de Herman Broch (1973, p.56), uma evidência "da exaltação de quem, desdobrando todas as energias espirituais, incluídas as artísticas, intenta elevar a uma esfera absoluta ou pseudoabsoluta os pequenos fatos cotidianos da vida terrena". Elas não deixam de participar, à sua maneira e na esfera doméstica, da "heroificação do indivíduo mediano" de que falam Adorno \& Horkheimer (1985, p.146), realizando, de maneira irônica para a perspectiva moderna que almeja libertar-se de todas as alienações, o ideal da beleza útil.

O quadro de Rubens Gerchman faz uma leitura pop, digamos assim, de tais fotografias, reafirmando, não sem ironia, o ambíguo caráter documental que elas apresentam. Ao "reproduzir" o modelo, desrealizando-o via desenho e pintura, Gerchman o reconhece como 
fato de cultura digno de atenção. Seu João e Maria reproduz estruturalmente as fotografias pintadas às quais remete, afirmando-se como simulacro de um modelo ao qual faltam justamente os traços da originalidade, da unicidade, da aura de que nos fala Walter Benjamin (1978). Clichê do clichê, o João e Maria de Gerchman afirma-se como sinédoque que, remetendo ao todo dos hábitos e das práticas culturais do país, atesta e comenta a nossa inserção subalterna na civilização do supérfluo e do banal marcada pelo ideal de consumo e por um imaginário reificado via serialização.

A transformação da imagem em sinédoque irônica que remete a um modelo e pretende abarcar todas as suas possíveis variações é operada, na tela de Gerchman, pelo texto escrito na moldura cor-derosa que enquadra a imagem do casal, onde lemos:

\section{'João eMaria coM eram.se...'}

\section{'a maram.se...'}

\section{'abandonaram.se..."}

\section{morreram.}

Embora essa reprodução esteja longe de igualar-se às cores e aos tipos de letra presentes no quadro, ela evidencia o conjunto de desdobramentos semânticos com que jogam cores, formas e tamanhos no texto que circula na moldura da imagem de João e Maria. Gerchman cria um texto circular que, enquadrando o casal, ironiza a vida previsível que caracteriza a sua paradoxal história "particular". $\mathrm{O}$ efeito de circularidade se encarrega de sugerir que tal história, já uma reprodução de modelo degradado, prolonga-se ao infinito, pois a cada ponto final é seguido de novo e idêntico começo ao qual sucedem os mesmos desdobramentos.

Lemos, nas frases, uma síntese das mil e uma histórias de amor que são uma só, marcadas por desejo, paixão, sexo, rompimento e morte. Note-se que o contraste das cores e do tamanho das letras encarrega-se de cumprir a função polissêmica que assinala um mes- 
mo e limitado conjunto de variações aos quais, afinal, reduzem-se todas ou quase todas as histórias de amor. Na primeira frase, lemos: João e Maria comeram-se, João e Maria conteram-se, pois há um T que se confunde com a cor da moldura, já que é formado apenas por um contorno em branco, e, já sugerindo o sexo, João eMaria coM/ Teram-se. Na segunda frase, lemos: amaram-se e também armaramse, já que há um $\mathrm{R}$ sutil construído como o $\mathrm{T}$ da frase anterior. $\mathrm{Na}$ terceira frase, lemos: abandonaram-se, adoram-se - o que assinala a antítese entre amar e abandonar ou, também, registra o paradoxo da paixão amorosa em crise já inscrito, note-se, na frase anterior. Finalmente, lemos na última frase: morreram, morram - o que sublinha a ironia com a qual o referente do quadro é comentado.

Gerchman pinta a imagem do casal com cores sombrias, o que equivale a um ácido comentário sobre a mistificação que caracteriza não apenas as fotografias pintadas que são o seu referente, mas o próprio roteiro do casamento previsivelmente sombrio e sem glamour dos milhares de Joões e Marias aos quais a imagem remete. Modo de fazer saltar à vista a banalidade do banal, mas por meio de linguagem sofisticada.

Segundo João Adolfo Hansen (1983, p.29),

Retomando tais objetos/hábitos/seres/formações imaginárias, reduplicando-os como redundância, fragmentando-lhes o caráter já fragmentário de resíduo e lixo, serializando-os obsessivamente [...], hiperbolizando-lhes a função de metáfora social "exemplar", o trabalho de Gerchman reconverte seu banal de fait divers a-histórico, impensado, à própria banalidade, inclui-os na superbanalidade de uma civilização do banal que, paradoxalmente, é refinadíssima no trabalho de exposição de seus limites de particularidade histórica idiota e fútil. [...] ocupando-se de representações sociais que poderiam ser determinadas como meramente bestas, irrelevantes e insignificantes, Gerchman extrapola-lhes o campo de horror "natural", devido à desrealização que seu trabalho efetua quando estabelece um vínculo associativo no receptor. Pois, coisa importante, neles, é a insistência na datação do imaginário: se a estupidez se vende e 
se um de seus procedimentos prediletos consiste em transformar o ainda-não, o quase, o pseudo, o in-significante etc. em pleno, cheio, em objeto privilegiado do desejo, objeto que é exposto institucionalmente como normalidade social do uso de tal ou qual palavra deslocada, como normatividade do gosto romântico do erotismo regressivo e anal, como controle de práticas racionais de produção de efeitos irracionais, nos trabalhos de Gerchman a imagem se faz como metáfora de tanta ruína, como memória do "tempo" do desejo, não mera metáfora substitutiva que envolve o espectador na "peste emocional", mas metáfora de uma ausência.

Ora, não deixa de ser curioso reconhecer que o quadro de Gerchman, feito na década de 1970 a partir de uma devoração da pop art, apresenta alguns elementos comuns às histórias de João e Maria escritas por Dalton Trevisan desde, pelo menos, os anos 1950-1960, a saber:

a) O tratamento irônico, dessacralizador, pontuado pela citação e pela paródia, conferido à união dos amantes. Veja-se, a título de exemplo, o conto "O senhor meu marido", que retoma intertextualmente o poema em prosa "Tragédia brasileira", de Manuel Bandeira (1985).

b) Há ênfase na afirmação dos contrários que caracterizam o amor-ódio da vida a dois: ‘A(R)MARAM.SE...'; ‘ABANDO-

NARAM.SE...'. A coincidentia oppositorum que articula sexo e violência está indiciada nas duas primeiras frases do quadro e é análoga a determinadas imagens que, nos textos de Trevisan, sintetizam, em frases curtas, as paixões características da ação dramática na ilíada doméstica. Veja-se, por exemplo: “em toda casa de Curitiba, João e Maria se crucificam aos beijos na mesma cruz" (Trevisan, 1978, p.61), frase que, extraída do conto “Dá uivos, ó porta, grita, ó rio Belém”, de 1978, foi transformada em miniconto do livro Ah, é? (Trevisan, 1994).

c) As frases do quadro compõem uma história mínima, maximamente reduzida de modo a flagrar os seus movimentos 
básicos e previsíveis. Além disso, o quadro, como os contos de Trevisan, sugere a morte como saída particular para o inferno doméstico que, no entanto, não elimina o problema, dada a eterna repetição do mesmo que prolifera incessantemente no plano da experiência coletiva.

d) As figuras humanas recebem um tratamento que, paradoxalmente, as despersonaliza em grau máximo no momento mesmo em que afirma a sua singularidade - o que põe o leitor na situação de assumi-las, ao mesmo tempo, como espectros dos Joões e Marias reais e como substância real, em sua espectralidade, de um imaginário coisificado ao extremo e reproduzido, na vida e na arte, num tempo convertido em eterno presente. Esse imaginário é, bem como as vidas que ele enforma, a matéria de escrita do escritor curitibano, cujas personagens, porque constituídas por linguagem reificada, revelam a sua natureza de clichês ${ }^{13}$ da máquina de narrar trevisaniana.

e) A linguagem pictórica afirma-se "realista" por meio de um paradoxo: parecerá, aos mais desavisados, uma retomada do figurativo recusado pelas vanguardas abstracionistas, quando, na verdade, é pintura de pintura, dialogando ironicamente com o ideal de abolição do figurativismo, com o ideal das cores e formas puras de certas vanguardas modernistas. Os textos escritos de Trevisan, embora projetem a ilusão naturalista de nascerem do estabelecimento de uma relação entre os signos que mobilizam e seus referentes reais, são literatura de literatura. A reescrita põe esse fato em evidência. Eleé, entretanto, passível de reconhecimento na própria relação entre o texto

13 Além da acepção usual para designar chavões e lugares-comuns de linguagem, destacamos, aqui, os vínculos do termo com as artes gráficas. A etimologia informa que o termo nasceu para designar a placa de metal que, gravada em relevo, destinava-se à impressão de imagens e textos em prensa tipográfica. O dicionário Houaiss eletrônico informa que o termo vem do francês: "clichê (1809) - 'chapa obtida pelo processo de estereotipia', part. pas. subst. de clicher 'estereotipar', talvez de origem onom. a partir do ruído da matriz abatendo-se sobre o metal em fusão”. 
e a versão pública codificada à qual ele remete e da qual se apropria para constituir-se como literatura.

f) A disposição das frases no quadro cria o efeito de circularidade que anula, por sugestão, o tempo linear, desdobrando-o, como já dissemos, em irônico eterno retorno - dispositivo que equivale, guardadas as devidas proporções, à repetição que caracteriza as histórias e - aparentemente - o trabalho de escrita de Dalton Trevisan, logrando, ali, alguns mesmos efeitos de sentido.

g) Tanto o quadro de Gerchman como os contos de Trevisan reconhecem, nos signos degradados dos quais se apropriam, o caráter daquilo que Roland Barthes (1987, p.152) chamou de mito: uma fala cuja função é transformar "um sentido em forma. Isto é, o mito é sempre um roubo de linguagem".

Feitas essas considerações, resta-nos afirmar, respeitando o paradoxo que caracteriza o trabalho de Trevisan, que o escritor curitibano cria, em sua literatura, algo que poderíamos classificar como abstracionismo pop, levando certos procedimentos da vanguarda modernista ao limite, se não de sua destruição, pelo menos de sua (auto)crítica.

José Paulo Paes (1984) estabelece uma interessante relação entre o trabalho de Trevisan e os koans da tradição zen:

Certa vez comparei os contos de Dalton Trevisan [...] a koans. Vale dizer, aquelas ilustrações de cunho paradoxal com que o mestre de Zen procura despertar no discípulo a compreensão intuitiva; imediata do real, esse peixe escorregadio que as mãos da lógica e da linguagem jamais conseguiram reter. A comparação não é despropositada, conquanto o contista jamais houvesse chamado koan a nenhum dos seus contos, deu a alguns deles o nome de haicais, o que é certamente uma aproximação. Haicais são tanto pelo laconismo da narração como pela total ausência nesta de qualquer empenho explicativo: o real é apresentado em estado bruto, como se captado fotograficamente. Daí poder-se aplicar, à maioria dos contos de Dalton Trevisan, aquilo que Leyla Perrone-Moisés observou a propósito 
do haicai: "A enunciação do haicai é a experiência do sujeito como lugar vazio, como receptividade, assentimento ao quid do real, do sujeito liberado de seus imaginários conceptuais e sentimentais".

A associação do trabalho de Dalton Trevisan com os koans da tradição zen é interessante porque reitera, para o que aqui nos interessa, o vínculo entre o mostrar característico da poética trevisaniana e a natureza da imagem e do processo de produção fotográficos. Note-se que Paes já assinala, também, a criação, na obra, de um efeito involuntário que sustenta a leitura aqui defendida no que se refere à alegorização e à espectralização que negam, às personagens e suas fábulas, qualquer substância de individualidade e, também, comentam, com ironia e por meio de uma visada metalinguística, o que é fazer arte e o que é ser artista no mundo contemporâneo.

Para permanecermos no terreno da metáfora de extração oriental, diríamos, por fim, que a obra de Dalton Trevisan reafirma de modo perverso e irônico a assertiva chinesa que define o Tao, a saber: o todo está em cada parte. Isso, tanto no que se refere ao plano da fabulação, com histórias que resultam de uma (i)limitada articulação da limitada morfologia das personagens e da combinatória limitada e previsível dos arranjos sintáticos estabelecidos entre elas, quanto no que se refere ao plano metalinguístico, a partir do qual o projeto literário trevisaniano dialoga criticamente com a tradição literária e com a arte moderna.

\section{Referências bibliográficas}

ABRAMS, M. H. El espejo y la lámpara. Teoría romántica y tradición clásica. Trad. Gregório Aráoz. Buenos Aires: Editorial Nova, 1962.

ADORNO, T. W.; HORKHEIMER, M. A indústria cultural: o esclarecimento como mistificação das massas. In: Dialética do esclarecimento. Trad. Guido Antonio de Almeida. 2. ed. Rio de Janeiro: Zahar, 1985. p.113-56.

ARAÚJO, J. de S. Próximo do haicai. In: TREVISAN, D. A trombeta do anjo vingador. 3.ed. rev. Rio de Janeiro: Record, 1981. (Orelha). 
BANDEIRA, M. Tragédia brasileira. In: Poesia completa e prosa. Rio de Janeiro: Aguilar, 1985. p.238.

BARTHES, R. O mito como linguagem roubada. In: Mitologias.

Trad. Rita Buongermino e Pedro de Souza. 7.ed. São Paulo: Difel, 1987. p.152-8.

. Estrutura da notícia. In: Crítica e verdade. Trad. Leyla Perrone-Moisés. 3.ed. São Paulo: Perspectiva, 2007. p.57-68.

BENJAMIN, W. A obra de arte na época de suas técnicas de reprodução. In: Textos escolhidos. Trad. José Lino Grunewald. São Paulo: Abril Cultural, 1978. p.5-28. (Os pensadores).

BERNARDI, R. M. Dalton Trevisan: trajetória de um escritor que se revê. São Paulo, 1983. Tese (Doutorado) - Faculdade de Filosofia, Letras e Ciências Humanas, Universidade de São Paulo.

BORBA FILHO, H. Curitiba: João e Maria. In: TREVISAN, D. Desastres do amor. 3.ed. rev. Rio de Janeiro: Civilização Brasileira, 1974. (Orelha). BRASIL, A. Dalton Trevisan: o mito de João e Maria. Jornal de Letras (Rio de Janeiro), p.262-5, jul./out. 1972.

BRITO, M. daS. Dalton Trevisan-um restituidor. In:TREVISAN, D. Morte na praça. 4.ed. rev. Rio de Janeiro: Civilização Brasileira, 1975a. (Orelha).

As batalhas de uma ilíada doméstica. In: TREVISAN, D. A guerra conjugal. 4. ed. rev. Rio de Janeiro: Civilização Brasileira, 1975b. (Orelha).

BROCH, H. Notas sobre el problema del kitsch. In: DORFLES, G. et al. (Org.) El kitsch. Antología del mal gusto. Trad. Jaume Pomar. Barcelona: Lúmen, 1973. p.49-67.

CAVALCANTI, V. A vida em flagrante. In: TREVISAN, D. Desastres do amor. Rio de Janeiro: Record, 1979. (Orelha).

CHKLOVSKI, V. Arte como procedimento. In: Teoria da literatura - Formalistas russos. Trad. Ana Mariza R. Filipouski et al. 2.ed. Porto Alegre: Globo, 1976. p.39-60.

GERCHMAN, R. Gerchman. Rio de Janeiro: Salamandra, 1989.

GOLDING, J. Cubismo. In: STANGOS, N. et al. (Org.) Conceitos da arte moderna. Trad. Álvaro Cabral. Rio de Janeiro: Zahar, 1991. p.38-57.

GOMES, Á. C.; VECHI, C. A. (Org.) Dalton Trevisan. São Paulo: Abril Cultural, 1981. (Literatura comentada).

HANSEN, J. A. Dados para uma identidade em RG. Arte em Revista (São Paulo), n.7, p.24-30, ago. 1983.

HARRISON, C. Expressionismo abstrato. In: STANGOS, N. et al. (Org.) Conceitos da arte moderna. Trad. Álvaro Cabral. Rio de Janeiro: Zahar, 1991. p.122-49. 
PAES, J. P. Meu querido assassino - Os pecados da babilônia curitibana. O Estado de S. Paulo, São Paulo, $1^{\circ}$ abr. 1984.

PAZ, O. Os filhos do barro. Trad. Olga Savary. Rio de Janeiro: Nova Fronteira, 1984.

READ, H. A arte de agora, agora. Trad. J. Guinsburg e Janete Meiches. São Paulo: Perspectiva, 1972.

SUBIRATS, E. Da vanguarda ao pós-moderno. Trad. Luiz Carlos Daher, Adélia Bezerra de Meneses e Beatriz A. Cannabrava. 3.ed. São Paulo: Nobel, 1987.

TÔRRES, M. Dalton Trevisan em dobro. In: TREVISAN, D. O vampiro de Curitiba. 2.ed. rev. e aum. Rio de Janeiro: Civilização Brasileira, 1970. (Orelha).

TREVISAN, D. Lágrimas de noiva. In: A guerra conjugal. 2.ed. rev. Rio de Janeiro: Civilização Brasileira, 1970. p.25-30. Lágrimas de noiva. In: A guerra conjugal. 4.ed. rev. Rio de Janeiro: Civilização Brasileira, 1975. p.19-24.

Dá uivos, ó porta, grita, ó rio Belém. In: Crimes de paixão. Rio de Janeiro: Record, 1978. Miniconto 187. In: Ah, é? Rio de Janeiro: Record, 1994.

VILLAÇA, N. Cemitério de mitos - Uma leitura de Dalton Trevisan. Rio de Janeiro: Achiamé, 1984.

WALDMAN, B. Do vampiro ao cafajeste: uma leitura de Dalton Trevisan. São Paulo: Hucitec, 1977. 


\section{4 \\ À PROCURA DE ILHAS \\ (DES)CONHECIDAS}

Maria Heloísa Martins Dias

quero encontrar a ilha desconhecida, quero saber quem sou eu quando nela estiver, Não o sabes, Se não sais de ti, não chegas a saber quem és [...]

(Saramago, 1998, p.40)

Talvez seja José Saramago um dos escritores que mais têm configurado, nas alegorias criadas em suas narrativas, a problemática da identidade (do sujeito? do país? do escritor? da própria narrativa?). Seja qual for a instância em que pensarmos, a dialética Eu-Outro desponta no trato com a ficcionalidade em Saramago. Como consciência inserida, desde sempre, no cenário das demandas culturais de seu país, o olhar crítico desse autor português contemporâneo acaba voltando suas lentes para flagrar com singularidade o espaço discutível que a nação ocupa e, nela, o indivíduo.

Parece-nos que a fala poética de Pessoa, o autor da Mensagem, em "Senhor, falta cumprir-se Portugal!", foi ouvida por Saramago e numerosos outros escritores que levaram a sério esse alerta e o incorporaram em suas criações. Com ou sem a pretensão de serem demiurgos, os ficcionistas vêm remodelando esse mote pessoano que também foi recuperado de outras vozes (Bandarra, Vieira, Garrett, Eça...). Enfim, as identidades literárias (será que existem?) deixam 
de o ser quando um fio-discurso coletivo enlaça Eu e Outro numa constante e aberta reciprocidade.

Voltemos à proposta de Saramago, que pode servir como ponto de partida para nossas reflexões, daí figurar como epígrafe.

A passagem citada pertence ao seu famoso texto $O$ conto da ilha desconhecida (1998), uma das poucas narrativas curtas do autor, cuja produção vem se concentrando em romances. A questão que me parece central, no entanto, é o porquê de nosso interesse por uma história cuja trama está calcada num absurdo - um homem a ir pedir um barco ao rei-, atitude considerada por essa personagem como um disparate. Então, por que o insólito, como móvel da narrativa, prende a atenção do leitor, o qual embarca numa aventura com essa ficção que já nos burla de saída? Porque sabemos, como leitores da literatura, que toda aparência ou evidência posta na escrita funciona como estratégia para a construção de um simulacro, e é esse objeto ou constructo, habilmente montado, que nos diz: vá à procura do que você não conhece, mesmo que isso não exista, a não ser no espaço aqui criado.

Ora, é essa a situação do conto de Saramago. A alegoria engenhada pelo autor, mais uma como tantas outras de suas narrativas, se faz de elementos simbólicos cuja inter-relação acena para sentidos conhecidos, para quem é leitor da ficção saramaguiana: a atração pela viagem, o visionarismo, a autodeterminação, a quebra de protocolos e hierarquias, a burla do poder autoritário, o desejo sem limites, o amor inexplicável.

Parece (apenas parece) loucura um pobre homem juntar-se a uma mulher de limpeza para irem num barco sem tripulação, sem conhecimento da "arte de marinharia", expressão do narrador, a navegarem à busca do desconhecido. É esse, afinal, o tênue enredo do conto. Na verdade, esse "louco varrido", como o rei considera a estranha personagem e todos os que "têm a mania das navegações" (Saramago, 1998, p.17), e a quixotesca limpadora de barcos que, "redemoinhando a vassoura como se fosse um espadão dos tempos antigos" (ibidem, p.33), espantava as gaivotas do barco, são sujeitos cuja identidade (desconhecida, eis o que importa) só se afirma como aventura que passam a construir. São os protagonistas de uma busca 
que não se explica nem se justifica, a não ser como um obsessivo estar à deriva. Um devir, uma não ancoragem.

Semelhante experiência nos oferecem as personagens de García Márquez (1985), mas num cenário totalmente distinto: Florentino Ariza e Fermina Daza vivem um amor guardado há meio século, navegando num barco que não ancora nunca. Mas, no romance do colombiano, a grande personagem é o amor (nos tempos do cólera) e não propriamente o país que as envolve. Também na narrativa de García Márquez, a viagem, para fora e para dentro dos sujeitos, constitui o espaço do inacabado, do impossível, do que só existe como procura, à deriva. Após terem vivido mais de meio século em distintos espaços e trajetórias de vida, as duas personagens se reencontram para uma aventura só justificada pelo ardor do desejo que as impulsiona, lançando-as num espaço destituído de dimensões lógicas e onde só reina a força do sentimento como margem conhecida.

Os exemplos seriam numerosos na literatura, portuguesa ou não, desse enigma crucial com que sempre nos debatemos: quem é que estou sendo? Para onde vou? $\mathrm{Ou}$, como se pergunta uma das veladoras de $O$ marinheiro, poema dramático de Pessoa: quem fala com a minha voz? Aqui tocamos num ponto essencial dessa discussão em torno do Eu e do Outro: a do estranhamento.

Sem precisarmos ligar essa questão ao problema da despersonalização, já analisada por diversos estudiosos da modernidade, ${ }^{1}$ interessa-nos abordá-la à luz de alguns pensamentos pertencentes à cultura contemporânea, como os de Homi Bhabha (1998). Em sua obra O local da cultura (Bhabha, 1998), a noção de unhomeliness (sentir-se estranho ao lar, desfamiliarização) é interessante para entendermos a forma como o autor concebe o processo das relações identitárias. Ao contrário do que as ideologias centralizadoras defendem para a sociedade, a instabilidade do desconhecido e o

1 Hugo Friedrich (1978), por exemplo, em A estrutura da lírica moderna, aborda esse e outros aspectos que marcam a poesia moderna, a partir de Baudelaire e outros autores de fins do século XIX que contribuíram para a afirmação de novas concepções líricas. 
abandono dos confortáveis recessos do espaço doméstico não põem em risco a afirmação do sujeito e seu conhecimento (nem o do país), ao contrário. A quebra de condicionamentos favorecida pelo trânsito em meio às incertezas é um risco, sim, porém contribui para a conquista de espaços (físicos e psíquicos) mais ousados, maleáveis à permuta entre as subjetividades em diálogo. Tal experiência, que Bhabha relaciona à vivência dos entrelugares, deve ser praticada pela aceitação das diferenças, do intervalo, das fronteiras móveis, o que significa abrir-se à desterritorialização.

Avesso às ideias de semelhança, identificação, permanência, continuidade, como traços para pensar a identidade, Bhabha insiste no deslocamento e na criação de uma outra dimensão ou outra margem em que circulam os sujeitos. Assim, "mover o enquadramento da identidade do campo da visão para o espaço da escrita põe em questão a terceira dimensão que dá profundidade à representação do Eu e do Outro - aquela profundidade de perspectiva que os cineastas denominam a quarta parede [...]" (Bhabha, 1998, p.81). Certamente é uma visão que pode sobressaltar, levando o sujeito a um mise-en-abîme ou a um labirinto a que não está acostumado, um espaço nada confortável, já que sem referências ou pousos seguros e com imagens deformadas pelo constante mover da câmera/olhar. Mas, graças justamente a esse deslocamento perturbador, em que nos defrontamos com o(s) outro(s) projetados além de nós mesmos, é que Eu e Outro deixam de existir como instâncias absolutas.

Não é fácil entregar-se a essa "quarta parede" sem resistências, pois a aventura, embora reveladora, provoca a desestabilização dos domínios conhecidos. É exatamente essa experiência que vive a personagem-narradora do conto "A mulher que prendeu a chuva", de Teolinda Gersão (2007). Na narrativa da autora portuguesa, o mise-en-abîme não se dá pela projeção desfocada de imagens nem pelo deslocamento espacial da personagem, mas pelo efeito de seu contato com algo insólito, que o desaloja totalmente de sua racionalidade e pragmatismo, promovendo o impacto desconfortável.

Enquanto arruma as malas em seu quarto de luxo para deixar o hotel em que se hospedara, a personagem do conto, um executivo, 
flagra uma conversa entre duas criadas que estão na sala contígua fazendo limpeza. Elas não percebem a presença do homem no cômodo ao lado, e uma delas conta uma história que teria se passado em uma aldeia africana: a terra do local secara e tudo morrera, animais, pessoas, plantas, sendo a catástrofe atribuída a uma mulher que, segundo um feiticeiro da região, prendera a chuva em seu corpo por causa do choro abundante de tristeza; após a intervenção de um jovem que com ela faz amor, ela aparece morta nos braços do desconhecido e a terra volta a florescer.

Os sentidos sugeridos pela história contada têm uma simbologia cósmico-erótica, mas não cabe aqui analisar; interessa-nos assinalar a reação do homem de negócios diante do relato da mulher. Como ele mesmo confessa para o leitor, algo naquela história o irritara profundamente, justo "eu, que nunca escuto conversas, muito menos conversas de mulheres [...]” (Gersão, 2007, p.83). Entretanto, o ponto de vista machista aliado ao espírito imediatista de sua profissão não consegue fazê-lo se distanciar daquela história que ficou a ouvir por sete minutos. $\mathrm{O}$ que de fato teria provocado a irritação no homem, que passa pelas criadas negras mal as cumprimentando, altivo e distante, na saída do quarto do hotel?

Homi Bhabha (1998) pode nos ajudar a responder. Quando vivemos a passagem para outro espaço, o que nos força a acolher o não familiar, no conto representado por uma cultura distinta da personagem, essa sensação de estranheza ou unhomeliness configura novos modos de percepção e sentidos para nossa existência, nem sempre assimilados ou aceitos. Assim, o executivo, cuja origem não é revelada no conto, coloca-se diante de um "pedaço de floresta virgem”, como ele mesmo diz, ali recortado, uma África plantada com suas personagens e histórias que desafiam sua compreensão não por causa da língua (que ele entende), mas pelos elementos simbólicos tratados com tanta naturalidade pela mulher africana. Eis o que o incomoda; a ficção penetra no real com força suficiente para perturbar as certezas do homem com relação a esses limites. Fascínio e terror, atenção e resistência - sensação dúplice que marca seu contato com a outra margem, ali tão próxima. Ainda que tenha 
ficado atento à história contada pela criada, sua recusa em partilhar daquela situação inusitada (feitiçaria, mulher que prende a chuva, sexualidade ligada à morte etc.) o faz afirmar, já no final da narrativa, ao decolar: "Lisboa é que não era, provavelmente, um lugar normal" (Gersão, 2007, p.84). Mais do que esse comentário, sua suposição de que, se contasse para alguém, não iriam acreditar nessa história, "toda a gente iria achar que eu estava bêbado, ou era louco" (ibidem, p.83), reafirma a posição inalterável do homem de negócios preso à sua lógica materialista, para quem uma cultura tão diferente da sua só pode soar como anormal.

Já em "Roma", outro conto da mesma coletânea da autora, o espaço anula a dimensão do sonho e do mítico para nos oferecer a realidade concreta, feita de injustiças e diferenças sociais. $\mathrm{O}$ ponto de vista da personagem, falando em nome de um "nós" que engloba o eu e uma outra personagem, reduzida a mera referência, aproxima os fatos do leitor, graças à exposição direta da visão crítica e das circunstâncias em que mergulha a personagem-narradora em sua aventura pela cidade italiana.

O passeio das personagens por Roma despe-se dos lugarescomuns que estão na mira da visão turística para se abrir a questionamentos sobre a temporalidade, o peso da tradição, o esvaziamento do espírito religioso, as imagens previsíveis, a falsidade da retórica discursiva. Percorrer o espaço se conjuga ao gesto decisivo de torná-lo um objeto de derrisão: "Mas só para disfarçar se invocavam deuses, era a si próprios que os humanos construíam templos, achámos, diante das ruínas de António e Faustina” (ibidem, p.49). Na ótica dessacralizadora da personagem, os monumentos históricos adquirem outra dimensão: "as praças eram íntimas, pequenas, mesmo a loba do Capitólio era pequena, tudo me parecia pequeno exceto o Coliseu, esse era feito à escala da barbárie humana, à medida do desejo de sangue e de espetáculo, com os seus múltiplos corredores subterrâneos [...]" (ibidem, p.49).

Mais ao final do conto, já não é o espaço de fora que é focalizado pela narradora-personagem, pois o flanar pela cidade se suspende para um interessante recorte cênico. A personagem se encontra em 
seu quarto de hotel e olha pela janela em direção ao prédio da frente. A partir de então, o "deix[ar-se] ficar atrás dos vidros", como ela narra, vai permitindo surgir um quadro que se singulariza, menos pelos elementos específicos que o compõem do que pela possibilidade de sentidos que ele abre à visão da personagem em sua experiência de ser viajante. Uma mulher de roupão surge na varanda e se debruça sobre vasos de flores, uma cabeça de criança aparece atrás da mulher e desaparece. Ambas se recolhem, a varanda se fecha, e outra janela do andar de cima se ilumina, de onde se ouve uma frase musical, vinda de um violoncelo, repetindo-se a intervalos. Contrariamente ao destaque dado antes, na narrativa, ao espaço da cidade e às sensações por ele provocadas na personagem, agora, na passagem mencionada, não é o público e sim o privado ou a intimidade que se projeta, emoldurada em sua temporalidade própria. Um tempo apegado aos impulsos e às necessidades individuais, sem o compromisso com o outro ou com o além de seus limites pessoais, e que, por isso mesmo, pode existir sem disfarces nem legendas artificiais, diferentemente, portanto, dos monumentos e templos históricos da cidade. É essa existência espontânea e legítima que possibilita à narradora exercitar seu imaginário: "Interroguei-me se ela levaria os vasos para dentro de casa, mas achei que decerto eram demasiado pesados para ela conseguir tirá-los do lugar" (ibidem, p.50).

Parece-nos, portanto, que a relação entre o eu e o outro no conto "Roma", de Teolinda Gersão, ganha profundidade quando o espaço da interiorização pode trabalhar as figuras com que essas duas instâncias se projetam. Isto é, quando se adensa a percepção voltada aos elos afetivo (mulher e criança) e artístico (música do violoncelo), pois é essa verticalização (lembremos que se trata de um prédio...) que constrói sensações permanentes.

Em afinidade com o imaginário que permanece na cabeça do viajante criado por Italo Calvino (1972), em As cidades invisiveis, para quem a cidade "é como uma armadura ou um retículo em cujos espaços cada um pode colocar as coisas que deseja recordar", na cabeça da personagem do conto de Teolinda Gersão (2007, p.50), o que permanece das imagens vistas em seu percurso é imaginar que, 
da Capela Sistina, pudesse reter "o momento em que as duas mãos se soltavam, a mão de Deus e a do homem, e começavam a distanciarse uma da outra - o momento exato em que essa distância começa a existir, era isso o que eu teria olhado na Capela [...]".

Pensar no jogo relacional entre identidades e alteridades é, sobretudo, pensar no devir ou nesse espaço em que se tecem as diferenças. Espaço privilegiado esse, pois aberto à circulação contínua do desejo, feito simultaneamente de luz e sombra, posse sempre adiada, perda e encontro, plenitude e vazio. Um espaço que a personagem masculina do conto de Teolinda Gersão não saberia e não desejaria viver, justamente porque essa modulação instável e intensa tem a ver com o próprio ato/gesto da escrita, realidade que escapa às dimensões lógicas de espaço e tempo. Quer seja entendida como devir, errância ou traço (i)legível (nos termos de Derrida ${ }^{2}$ ), quer como significância (definida por Kristeva e retomada por Barthes ${ }^{3}$ ), a escrita coloca em jogo as tensões entre o eu-que-diz e o outro-que-se-vai-dizendo, isto é, o corpo do sujeito e o do discurso autogeram-se em perpétuo movimento, mas não necessariamente rumo a um encontro ou plenitude.

A meu ver, um dos melhores exemplos de escrita com essa natureza singular se encontra na poesia de António Ramos Rosa, referência fundamental na literatura portuguesa que, desde 1958, vem produzindo obra considerável no campo da poética e no da crítica.

Em seu livro Pátria soberana seguido de nova ficção, ${ }^{4}$ Rosa (2001) envereda por uma senda inédita, em que o apelo erótico da escrita de outras obras suas se converte numa reflexão sobre o espaço da pátria (página?) - corpo que, como o da palavra, se tece de múltiplas relações. Vejamos, por exemplo, o poema apresentado a seguir.

2 Tais noções são apresentadas em seu já clássico livro A escritura e a diferença (Derrida, 1971), mas estão presentes, de certa forma, em suas reflexões ao longo de seus escritos.

3 A significância, tal como esses críticos definem, corresponde ao processo de germinação dos sentidos, espaço móvel e dinâmico em que a escrita se produz sensualmente.

4 Obra com que Ramos Rosa ganhou o Prêmio Literário Ruy Belo 2001. 
Quando a pátria lasciva espalha os seus odores

Dionisos sente que o seu campo é vermelho e dança em espirais de fogo com as bacantes ébrias

Não é o caos mas a violência tremenda do instinto em unidade incandescente em gestação de lava oceânica O uno manifesta-se na multiplicidade dos membros que se enlaçam na felicidade imediata de serem a mesma onda irrevogável que os une a todos em manifesta essência A pátria está aqui presente como universal visão da gênese tumultuosa das figuras que a dança unifica em simetrias circulares em espirais vermelhas (Rosa, 2001, p.27)

Ao investir na figura circular e na imagem de Dionisos para caracterizar a pátria, o poeta a um só tempo rompe com a visão apolínea, equilibrada e racional da consciência artística na apreensão do real, como também transforma essa entidade histórica (pátria) em corpo sensual, maleável aos movimentos e impulsos criativos. Essa pátria minúscula que figura no poema é um sujeito lascivo a "espalha[r] os seus odores" (primeiro verso), por isso não se ergue como monumento monolítico, centralizador e severo para os homens, mas sim como uma dança em perpétuo dinamismo, alimentada pela força de Eros.

Identidade proteica, a pátria surge, na visão poética de Ramos Rosa, como ser híbrido e em permanente metamorfose, o que implica a rasura das hierarquias e dos valores demarcados, a fim de promover o deslocamento das figuras e seu enlace, graças ao acolhimento do múltiplo. Desse modo, a noção de unidade arrebenta-se em favor das "simetrias circulares" e das "espirais vermelhas" (último verso), configuração que promove, também, a quebra da visão tradicional de unificação. Não se trata de uma somatória de elementos ou de mera complementaridade, mas de uma "gênese tumultuosa das figuras" (penúltimo verso), ou seja, a explosão criadora não se faz do 
acréscimo e sim das pulsões e dos instintos diversos que movem os sujeitos. O resultado, a "unidade incandescente" (quinto verso) que vem da "violência tremenda do instinto" (quarto verso), contraria as sensações de tranquilidade, paz ou harmonia a envolverem a noção de pátria, sugerindo, ao contrário, a instabilidade, não caótica, mas potencializadora de novos movimentos.

Tal espaço, que também é o espaço do desejo, inscreve a pátria num lugar muito mais amplo, na verdade, um não lugar, ou melhor, um aqui provisório, aberto para acolher outros espaços: "A pátria está aqui presente como universal visão” (décimo primeiro verso). Trata-se, portanto, de um espaço por-se-fazer, liberto e agenciador de elos intensos e instáveis; o presente como "um lugar expandido e ex-cêntrico de experiência e aquisição de poder" (Bhabha, 1998, p.23).

Longe dos ideais pregados por um nacionalismo ingênuo (ou conservador), o posicionamento do poeta diante da pátria a desaloja dessa convenção, transformando-a em signo do desejo, em que os "membros" desse corpo coletivo não se unem por laços preestabelecidos, e sim por sentidos que eles mesmos vão construindo com a força de seus impulsos. É o que a linguagem poética encena para o leitor em seu fazer. Para isso, concorre a presença de sons sibilantes em diversos signos do poema, criando um corpo significante ideal para materializar a sexualidade que enlaça terra e homens: lasciva / espalha / odores / Dionisos / dança / espirais / violência / instinto / incandescente / gestação / oceânica / enlaçam / felicidade / serem / manifesta / essência / universal / visão / espirais / simetrias circulares.

Toda essa matéria tornada incandescente e sonora pela linguagem marca-se também pela sensação visual, que se reitera pelos versos. É como se a construção da pátria demandasse, de fato, uma visão sensível para dar conta de seus apelos mais intensos, o que só é possível por esse "campo vermelho" onde as figuras da linguagem podem dançar como Dionisos e suas bacantes.

Em outro poema de Ramos Rosa (2001, p.41-2), contido em "Nova ficção", última parte do livro Pátria soberana, já citado, encontramos: 
Nada indica à Figura uma só linha solar e ela sente o vão do seu frágil vôo sobre o silêncio sem substância sobre o indeterminável vazio

Os seus instrumentos não são a trompa nem a harpa mas o sangue do vento ou o ócio da água Ela levanta-se sem saber porque se levanta ou por uma pressão indefinível e obscura que requer a respiração de uma dilatada esfera

Mas em cada impulso de asa para o azul ela quer retornar à casa que não tem Ela aspira a ser um elemento puro uma pausa habitável um círculo harmonioso

Toda a sua abstrata viagem é um erro errante uma violência contra a violência do sentido e do não sentido um lascivo infortúnio irreparável

Mas ela sente o sabor solar do único como um membro incestuoso na sua boca e é por isso que às vezes o seu vôo desenha uma ilha onde o sossego é verde e libidinoso

Se a distância se convertesse numa folha de música ela teria construído a estrutura de um arco uma coluna ou um tronco de substância azul e esse seria o resultado e o princípio do seu vôo

No contexto do livro em que se encontra, a Figura (maiúscula) apontada no primeiro verso corresponde à pátria, espaço que vai sendo remodelado pelo olhar lírico à medida que sua reconfiguração se confunde com o espaço da linguagem e da página que a acolhe como corpo. 
O que nos importa salientar é a visão poética ou a perspectiva que vai traçando o espaço pátrio, responsável por desfazer o mito da plenitude ou certeza de seus contornos, menos ainda o espírito solar, apolíneo, de sua imagem. Ao contrário, a fragilidade, o silêncio, a falta de substância e o vazio são marcas de uma realidade precária, que não mais alça voo à conquista de outras terras, nem impõe sua voz; o escoamento de seu conteúdo e a não nitidez de seu corpo são sinais de que outro, diferente, percurso deve se construir para a Figura sem nome que os versos enunciam. Negando o canto épico e o canto lírico, encarnados nas metonímias "trompa" e "harpa" (segunda estrofe), o eu poético propõe outro instrumento para a figura pátria: "o sangue do vento ou o ócio da água”. Ou seja: não a fala, mas substâncias concretas, mesmo se materializadas no incerto e indefinível que as movimentam. É assim que a pátria se levanta, dilatada por um impulso inexplicável, inerente à sua própria condição; aqui se esboça aquele desejo de cumprir-se Portugal, de que já falara Fernando Pessoa, em Mensagem, e que outras vozes fizeram ecoar também em suas poesias.

O poema vai construindo a dialética vivida por essa "esfera", tensionada entre a abertura para o além, a sua "asa para o azul", e a fixação em seu próprio seio, "retornar à casa”, o aquém - exterioridade e interioridade como espaços ou pulsões necessárias e complementares, porém contraditórias (terceira estrofe). O desejo de trânsito para abolir fronteiras e ganhar mobilidade é tão intenso quanto o de permanecer ou habitar num espaço conhecido, tensão que se presentifica com insistência no percurso histórico desse país, dividido entre dar as costas ao mar e voltar à terra ou abandonar esta para ir em busca daquele, ambos caminhos vitais para a solidificação de sua história. Note-se, porém, como é modalizado o espaço de dentro, o da terra: é uma casa "que não tem" (segundo verso), isto é, a aura de familiaridade que legitimaria o reencontro dos mitos idealizados do passado (heroísmo, identidade nacional, harmonia, segurança etc.) não existe. Estamos novamente diante daquela visão crítica que o poeta já nos apresentara no poema analisado antes. O espaço a ser ocupado pela Figura, metáfora da pátria, só 
pode se vislumbrar como entrelugar, corroborando a ideia de Homi Bhabha (1998, p.20) de que só "esses 'entre-lugares' fornecem o terreno para a elaboração de estratégias de subjetivação - singular ou coletiva - que dão início a novos signos de identidade e postos inovadores de colaboração e contestação, no ato de definir a própria idéia de sociedade".

A quarta estrofe recupera o motivo da viagem, qualificando-a de abstrata, já que movida por visionarismos sem sentido, "um erro errante" (primeiro verso): a errância, em sentido totalmente contrário ao que lhe atribui Jacques Derrida (1971), é vista como danosa e um equívoco, pois alimentou falsos ideais no imaginário coletivo, responsável pelo que Eduardo Lourenço (1991, p.37) define como "culto patológico da 'lusitanidade', ajudando [...] a radicalizar nos termos mais cegos e dementes uma política 'imperial' cujas funestas conseqüências não escaparam a gente menos 'visionária' e menos delirantemente "patriótica"” (1991, p. 37).

Tal como no outro poema já analisado, também neste o espaço da pátria se reveste de erotismo, o que se mostra em expressões como "dilatada esfera", "lascivo", "membro incestuoso", "libidinoso". É na quinta estrofe que se intensifica a componente erótica, momento em que o poeta alude ao desejo do corpo pátrio de experimentar "o sabor solar do único" (primeiro verso). Como entender esse desejo? O que corresponderia ao único? Se pensarmos, como já comentamos, na rasura das noções de integridade, unicidade, unidade etc., em relação à pátria, talvez fique mais claro o sentido proposto pelo poeta nesse verso: ao procurar uma ilha onde possa fruir seu sossego ("verde e libidinoso”), essa figura abstrata concebida pelo eu está desejando afastar-se para um espaço em suspensão, à distância, não marcado pelas relações previsíveis e determinadas. Gesto "incestuoso", certamente, como enuncia o segundo verso, pois contrário às convenções ético-sociais, vivendo a sua marginalidade e autossuficiência. ${ }^{5}$

5 Gesto, de certa forma, análogo àquele narrado em A jangada de pedra, de José Saramago, alegorizado na jangada à deriva, a viver de sua errância e à distância do continente do qual se desgarra. 
O final do poema, no entanto, denuncia o caráter hipotético dessa vivência (marcado linguisticamente pelo "se"), só possível no espaço da utopia, ou melhor, da atopia, um não lugar, porque a distância não pode figurar como desejo absoluto. Ao mesmo tempo tronco e voo, a solidez e a impermanência, a racionalidade e o imaginário, a pátria é uma Figura (ir)real que a poesia corporifica.

José Saramago, Gabriel García Márquez, Teolinda Gersão, António Ramos Rosa, aqui trazidos, são alguns nomes de uma produção literária que vem lançando suas chamas criadoras para iluminar os possíveis sentidos de uma busca insaciável: a relação polimórfica entre o sujeito e o mundo, corpos em permanente construção, identidades fluidas e postas no risco da aventura, em espaços imaginários, porém intensamente legítimos.

\section{Referências bibliográficas}

BARTHES, R. O prazer do texto. São Paulo: Perspectiva, 197.

BHABHA, H. O local da cultura. Belo Horizonte: UFMG, 1998.

DERRIDA, J. A escritura e a diferença. São Paulo: Perspectiva, 1971.

FRIEDRICH, H. A estrutura da lírica moderna. São Paulo: Duas Cidades, 1978.

GERSÃO, T. A mulher que prendeu a chuva. Lisboa: Sextante, 2007.

LOURENÇO, E. O labirinto da saudade. 4. ed. Lisboa: Dom Quixote, 1991.

MÁRQUEZ, G. G. O amor nos tempos do cólera. Rio de Janeiro: Record, 1985.

ROSA, A. R. Pátria soberana seguido de nova ficção. Vila Nova de Famalicão: Quasi, 2001.

SARAMAGO, J. O conto da ilha desconhecida. São Paulo: Companhia das Letras, 1998. 


\section{5 \\ MACHAdO de Assis À LUZ DO CINEMA DE SÉRGIO BIANCHI: O ESPAÇO EM MOVIMENTO}

Sérgio Vicente Motta

Os filmes de Sérgio Bianchi têm uma raiz machadiana, instaurada desde A causa secreta, de 1994, o mesmo título de um conto do escritor, passando por Quanto vale ou é por quilo?, de 2005, também baseado em outro texto do autor. No restante da obra, mesmo não tendo esse apoio mais explícito, é possível identificar um rastro de violência apontado por Machado nos subterrâneos do homem e da sociedade brasileira, que o diretor traz à tona para retratar criticamente aspectos que persistem "cronicamente" nas malhas dessa sociedade.

Pode-se dizer que Sérgio Bianchi elege um tipo de leitura na obra machadiana e faz dela um meio de "reler" as contradições, os mecanismos de empenho, dominação e exploração que permeiam as relações de nossa sociedade contemporânea. Os seus filmes, na singularidade de sua estética e consistência artística, têm autonomia e se apresentam como uma das vertentes mais criativas e expressivas do cinema brasileiro moderno. Mas vê-los também por meio desse diálogo estabelecido com a obra de Machado é uma maneira de buscar algumas linhas temáticas e formais inspiradas pela literatura, que são trabalhadas e desenvolvidas em seus filmes. Uma delas, sem dúvida, é a permanência de traços absorvidos pela nossa sociedade escravista, que ainda não se apagaram; ao contrário, ganharam expressões próprias, num processo perverso de metamorfoses flagradas em seus 
filmes. Familiarizados no convívio cotidiano, esses ecos dos porões da escravidão estão incorporados ao corpo social como a sombra do passado que a luz do seu cinema quer ressaltar.

É esse o vínculo principal que liga o conto "Pai contra mãe", publicado por Machado em 1905, ao filme Quanto vale ou é por quilo?. Como o passado ainda vive no presente é um caminho de leitura para o filme, que, ainda, realça, no seu diálogo profundo com a obra, aspectos da literatura de Machado do ponto de vista da sua escritura e da crítica social. É este o objetivo deste texto: apontar como Machado sugeriu uma possibilidade de deslocamento no tempo e espaço de uma estrutura social, que o diretor captou, deu forma e consistência na sua arte cinematográfica um século depois.

Levantaremos, como ponto de partida, alguns aspectos da composição do conto e de suas implicações temáticas que dialogam com o filme nessa intermediação de um sistema e linguagem para outro meio de comunicação e expressão.

\section{"Para pôr ordem à desordem"}

No texto de Machado, podemos destacar duas partes, de acordo com os seus núcleos temáticos e a sugestão de certas características discursivas. Uma, constituída pelos cinco primeiros parágrafos, trata dos "ofícios e aparelhos" legados pela instituição da escravidão. Por ser de teor descritivo, simula um discurso histórico com função documental. A outra conta a "história de uma fuga", dramatizando a institucionalização de um desses ofícios, o capitão do mato. Mas tudo é ficção e, mais do que contrastar dois tipos de gêneros discursivos, um de aparência histórica e outro marcadamente ficcional, o texto promove uma ligação entre eles, por meio de um fio enunciativo de primeira pessoa, que atua nos dois blocos para fazer aflorar toda a violência subjacente com a aparência de um processo "quase" natural.

A aparência documental do primeiro bloco também contrasta um tom narrativo sério - dada a gravidade da violência implicada no uso dos "aparelhos" - e irônico, com a intromissão do comentário da voz 
de primeira pessoa, que faz resvalar o dramático da situação para o cômico das falsas conveniências morais e religiosas: "A máscara faz perder o vício da embriaguez aos escravos, por lhes tapar a boca. [...] Com o vício de beber, perdiam a tentação de furtar [...] e aí ficavam dois pecados extintos, e a sobriedade e a honestidade certas" (Assis, 1998, p.483). Ou seja, os fins justificam os meios. Entre a aplicação da violência e a sua justificativa, abre-se uma fenda - os olhos da máscara de tortura - por onde se infiltram os olhos do leitor para ver dentro e fora dela, dessa instituição (a escravidão), que se colou ao corpo da sociedade brasileira, num determinado tempo foi arrancada, mas cujas marcas jamais foram apagadas. É assim, na soldagem dessa duplicidade de dois contrastes, que o texto se costura dialeticamente, à maneira como a desordem do corpo social se conforma à ordem da máscara para produzir a síntese da mistura: "Era grotesca tal máscara, mas a ordem social e humana nem sempre se alcança sem o grotesco, e alguma vez o cruel" (ibidem). A ironia do narrador trabalha no mesmo compasso da ordem social. Funde a violência da denúncia à aparência de normalidade no comportamento social: "Os funileiros as tinham penduradas, à venda, na porta das lojas” (p.483).

O que pode quebrar essa ordem social - outra fissura na estrutura que começa a se desenhar, formada pelo torturador, o produtor do instrumento de tortura e o torturado - é a "fuga" do escravo. Essa é a causa principal que justifica tanto o uso dos "aparelhos" quanto os "ofícios" que ela gera. Para evitar a fuga, entram mais dois instrumentos: o "ferro ao pescoço" e o "ferro ao pé". Como diz o narrador: "Não cito alguns aparelhos senão por se ligarem a certo oficio” (p.483). Ou seja, nessa ironia disfarçada com uma aparência de naturalidade, o tema da fuga vai puxar o motivo da captura, o verdadeiro ofício que a instituição da escravidão gerou e que o narrador quer destacar.

Assim, depois de mostrar as várias perspectivas de fugas, essa parte é dedicada a justificar, sempre ironicamente, o novo ofício legado, seja pela "nobreza" de sua função social reguladora - "por ser um instrumento de força com que se mantêm a lei e a propriedade" -, seja pela necessidade social ou aptidão individual: "a pobreza, a 
necessidade de uma achega, a inaptidão para os outros trabalhos, o acaso, e alguma vez o gosto de servir também, ainda que por outra via, davam o impulso ao homem que se sentia bastante rijo para pôr ordem à desordem" (p.484).

\section{"A história de uma fuga"}

A outra parte, a "história de uma fuga", funcionando como uma contrapartida irônica de um acontecimento histórico, torna-se a história de uma caçada. Nesse deslocamento, o foco sai do lugar ocupado pelo escravo (a caça) e dirige-se para o território do pegador de escravos fugidos (o caçador), gerando, em relação ao ponto de partida representado pela casa do senhor de escravo, uma "terceira margem" na configuração social colonial. As relações entre esses três vértices instauram uma estrutura triangular dinamizada por um mecanismo dialético. A partir das relações de tensão entre os polos anteriormente constituídos, formados pelo "senhor de escravo" e o "escravo", surge o elemento que os liga, complementa e os sintetiza: o "caçador de escravos". Essa representação, esquematizada em uma estrutura triangular e impulsionada por um mecanismo dialético, será tomada como o fio condutor da análise da narrativa fílmica proposta por Sérgio Bianchi a partir desse conto de Machado de Assis. Por ter um papel fundamental e sugerir as suas principais vias temáticas, essa parte será analisada com mais detalhes.

Esse bloco textual, ágil e direto, começa anunciando o "ofício" escolhido pelo personagem principal e a consequência da escolha: "Cândido Neves - em família, Candinho, - é a pessoa a quem se liga a história de uma fuga, cedeu à pobreza, quando adquiriu o ofício de pegar escravos fugidos” (p.484). Não bastasse a concentração irônica nos nomes (oficial e familiar) e no sobrenome, em relação à violência que o conto prepara a uma escrava negra, a ironia do narrador, agora, no discurso que se assume narrativo, permuta aquela pele de naturalidade por uma roupa de "malandragem" disfarçada em "caiporismo": "Tinha um defeito grave esse homem, não agüentava emprego nem 
ofício, carecia de estabilidade; é o que ele chamava de caiporismo" (p.484). Essa metamorfose do discurso, do efeito histórico mais tenso ou "oficial" para o efeito de liberdade ficcional, em sintonia com a natureza do personagem ("Cândido quisera efetivamente fazer outra coisa, não pela razão do conselho, mas por simples gosto de trocar de ofício; seria um modo de mudar de pele ou de pessoa"), mostra como ele troca a formalidade de várias oportunidades (tipógrafo, caixeiro, fiel de cartório, contínuo de uma repartição, carteiro, entalhador) pela informalidade do ganho fácil, rápido e descompromissado.

Seguindo um andamento cômico, impulsionado pelo "riso" fácil e o motivo do casamento, a fábula cuida de juntar os três personagens principais desse núcleo narrativo: tia Mônica, a sobrinha Clarinha e seu futuro esposo, Candinho. Com a ironia e destreza do narrador, inclusive para se opor à falta de habilidade do personagem, a narração acompanha a agilidade e o tom da narrativa: "O encontro deu-se em um baile; tal foi - para lembrar o primeiro ofício do namorado - tal foi a página inicial daquele livro, que tinha de sair mal composto e pior brochado" (p.485).

Logo a seguir, em sintonia com as metamorfoses do personagem, o discurso aproxima-se do trágico, o qual, do fundo de sua morada, começa a espreitar a família. O elemento deflagrador é o desejo de um filho, apesar da não concordância da tia: "Um dia, porém, deu sinal de si a criança; varão ou fêmea, era o fruto abençoado que viria trazer ao casal a suspirada ventura. Tia Mônica ficou desorientada, Cândido e Clara riram de seus sustos" (p.486). O riso puxa a tristeza, sua sombra, que logo é apontada pela tia: “-Vocês verão a triste vida, suspirava ela” (p.486). Assim, destravada pela falta de um ofício, a roda da fortuna irrompe e só tem como possível resistência a incerta ocupação de Candinho: “-Sim, mas lá vem uma noite que compensa tudo, até de sobra. Deus não me abandona, e preto fugido sabe que comigo não brinca; quase nenhum resiste, muitos entregam-se logo" (p.487). Agarrado à "esperança como de capital seguro", Candinho assume de vez o ofício: "Pegar escravos fugidos trouxe-lhe um encanto novo. Não obrigava a estar longas horas sentado. Só exigia força, olho vivo, paciência, coragem e um pedaço de corda" (p.487). 
Se não aprendia a "compor", sabia ler com precisão, em nova correlação do personagem com o narrador: "Cândido Neves lia os anúncios, copiava-os, metia-os no bolso e saía às pesquisas. Tinha boa memória. Fixados os sinais e os costumes de um escravo fugido, gastava pouco tempo para achá-lo, segurá-lo, amarrá-lo e levá-lo” (p.488). Porém, um dia os lucros entraram a escassear e, no dizer do narrador, "como o negócio crescesse, mais de um desempregado pegou em si e numa corda, foi aos jornais, copiou anúncios e deitou-se à caçada" (p.488). A situação financeira fica cada vez mais complicada à medida que aproxima a data do nascimento da criança, e o narrador, jogando com o desespero da família, afinal revela o conselho que lhe "custa escrever": "Foi na última semana do derradeiro mês que a tia Mônica deu ao casal o conselho de levar a criança que nascesse à Roda dos enjeitados" (p.489).

A roda da fortuna pode deter a roda dos enjeitados? Esse é um embate entre a ficção, que pode encaminhar suas soluções para as malhas do destino, e a história, que intervém para detê-la com as garras do poder social. Por isso, na ficção, agora começa o drama representado pela disputa entre a vida e a morte, cujo desfecho trágico terá como fiel da balança o peso social. É o que se vê com a cena da "caçada", tramada a partir da fuga de uma escrava e o retorno à casa do proprietário.

Para representar o primeiro movimento, da casa à rua, Machado coloca ironicamente, para viver na pele o papel de vítima do sistema, o próprio Candinho, que se vê ameaçado pelo credor ("- Cinco dias ou rua! Repetiu, metendo a mão no ferrolho da porta e saindo”) e é salvo, a princípio sem o saber, pelo empenho da tia e pelo obséquio do "favor": "Postos fora de casa, passaram ao aposento de favor, e dois dias depois nasceu a criança. A alegria do pai foi enorme, e a tristeza também. Tia Mônica insistiu em dar a criança à Roda" (p.491).

A roda fica na Rua dos Barbonos, e o drama, levado às ruas, é encaminhado pela ironia dos seus nomes ("rua do Parto e da Ajuda"), pois é justamente da "ajuda" pelo "parto" frustrado no aborto que Candinho será pai e Arminda impedida de ser mãe. Arminda é o nome da escrava fugida, cujos dados estão no cartaz que Candinho 
lê na "rua da Ajuda", quando conduz, contrariado e como última esperança, o filho recém-nascido à roda dos enjeitados. Sem outra saída, a não ser afrouxar o passo, entra na "rua da Guarda Velha", passa "por um dos becos que ligavam aquela à rua da Ajuda", quando vê a mulata fugida: "Não dou aqui a comoção de Cândido Neves por não podê-lo fazer com a intensidade real. Um adjetivo basta; digamos enorme" (p.492). A intromissão do narrador é uma forma de alerta para o que está indicado. Ao analisar a emoção do personagem, para poder descrever a sua intensidade, recorre ao adjetivo "enorme", pois é esse senso de desproporção que está em jogo. Ele liga a alegria de um à dor do outro, a ponte movediça que faz a mediação entre a superfície de uma situação social e o fosso em que se debate para sobreviver o seu inverso real.

Na sequência, Candinho deixa o filho na farmácia em que obtivera informações da escrava e, quando ela ia descer a rua "S. José", surpreende-a, atando-lhe os pulsos. Apesar da súplica, propondo-lhe até ser sua escrava, e de dizer que estava grávida, Arminda é arrastada "pela rua dos Ourives, em direção à da Alfândega, onde residia o senhor" (p.493). Depois de muita resistência e luta, chegam ao desfecho do "espetáculo" em situações opostas: "Cândido Neves guardou as duas notas de cinqüenta mil-réis, enquanto o senhor novamente dizia à escrava que entrasse. No chão, onde jazia, levada do medo e da dor, e após algum tempo de luta a escrava abortou" (p.494).

O espetáculo caminha para o final, com a tragédia cedendo lugar, novamente, à comédia: "O fruto de algum tempo entrou sem vida neste mundo, entre os gemidos da mãe e os gestos de desespero do dono. Cândido Neves viu todo esse espetáculo” (p.494). Em seguida, corre à farmácia, resgata o filho, como adverte o narrador, "com a mesma fúria com que pegara a escrava fujona de há pouco, fúria diversa, naturalmente, fúria de amor” (p.494). Há aí, nessa cena carregada de paixão, o sentimento de fúria, mas uma "fúria de amor", diversa do ódio expresso um pouco antes, quando chega à farmácia e, não vendo o filho, ameaça "esganar" o farmacêutico, que havia levado o menino para dentro da casa, ao abrigo da família. Também diversa da fúria anterior, insuflada pela violência da luta 
para dominar a escrava fujona. Enfim, a oposição entre vida e morte, que movia o drama, converte-se, agora, em uma comédia de paixões: amor e ódio. Como aquele, esse teatro também é dialético.

É esse fingimento de amor em uma causa egoísta que encobre o interesse, o ódio e o desprezo mascarados nas causas altruístas, configurando a verdadeira "causa secreta" que Machado quis revelar na estrutura violenta dessa hierarquização social. Por isso, Candinho, de posse do menino, retorna para a comemoração: "Agradeceu depressa e mal, e saiu às carreiras, não para a Roda dos enjeitados, mas para a casa de empréstimo, com o filho e os cem mil-réis de gratificação" (p.494). É esse jogo de interesse que explica também o perdão de Candinho por tia Mônica, ao mesmo tempo que ela condena Arminda: "Tia Mônica, ouvida a explicação, perdoou a volta do pequeno, uma vez que trazia os cem mil-réis. Disse, é verdade, algumas palavras duras contra a escrava, por causa do aborto, além da fuga" (p.494). Do perdão chega-se à bênção, nessa cadeia de paixões, pois não importam os meios, já que os fins justificam os princípios, tanto dos fatos quanto da moral: "Cândido Neves, beijando o filho, entre lágrimas verdadeiras, abençoava a fuga e não se lhe dava do aborto" (p.494). E conclui: "-Nem todas as crianças vingam, bateu-lhe o coração" (p.494).

No drama a que acabamos de assistir, alguém tem que pagar com a morte o preço de uma vida: "Pai contra Mãe". Na comédia que emerge do drama, o peso da paixão transforma o ódio em "fúria de amor", nesse "espetáculo", cuja palavra-síntese é o adjetivo "enorme". Nos círculos dessa paixão egoísta e cínica, toda a carga dramática e trágica dos fatos aporta na acomodação cômica da ironia que, embora aponte e desmascare uma relação de contradição entre esses fatos, não tem ainda o peso de um "sentimento do contrário", a síntese do processo, que ultrapassa o patamar da "advertência do contrário" ou da percepção de uma contradição, onde residem a ironia e o cômico, e funda o seu sentido mais profundo no trágico e no "humor" (Pirandello, 1996, p.132). É esse "sentimento de uma contradição" que parece ser a "causa secreta" dos contos de Machado e é traduzido, aqui, em uma espécie de paixão da "fúria", 
um sentimento que abarca e acomoda, dialeticamente, a contradição entre o amor e o ódio.

Ódio racial. Ódio social. Elementos que vão embeber complexas relações de preconceitos na sociedade brasileira. O "outro" visto como mercadoria e a exploração da pobreza como produto gerador de riqueza são alguns aspectos temáticos que nascem das intermediações das arestas dessa estrutura triangular e que são reduplicados com pertinência nas sequências narrativas do filme coerentemente denominado Quanto vale ou é por quilo?. Antes de passarmos ao filme, é preciso explorar um outro sentido escondido na frase que expressa a conclusão de Candinho e finaliza o conto.

Ao dizer que "nem todas as crianças vingam", com o bater do “coração" há, no comentário do narrador, um desvio vertiginoso, para não dizer "enorme", de toda a implicação racional da história para uma solução emocional, como se o "coração" fosse a fonte de expressão, o que pode, se forçarmos um pouco a interpretação, nos lembrar de uma manifestação em estado bruto e irônica do famoso conceito de "cordialidade" criado por Sérgio Buarque de Holanda. Depois, para fixarmos no segmento da frase que pressupõe a voz de Candinho ("- Nem todas as crianças vingam"), podemos, primeiro, destacar a ambiguidade do verbo "vingar", que, no plano social, demonstra todo o cinismo da dominação do mais forte sobre o mais fraco e suas implicações irônicas, as quais vão do plano histórico-social ao contexto filosófico e científico-cultural. As crianças "vingam" como plantas, naturalmente, como se acreditava no positivismo e no naturalismo da ciência e das artes. Além de mostrar mais uma vez, e, agora, como conclusão do conto, a maneira como a sociedade mascara com um véu de "naturalidade" a deformidade de sua face real.

Mas há, ainda, um outro sentido latente no verbo "vingar", que remete à nomeação de todo o processo, na sua versão substantiva: "vingança". Nesse sentido mais abrangente, o campo semântico da palavra abriga, além das possibilidades anteriormente lembradas e mais atreladas ao contexto do conto, um outro significado: aquele relacionado à "vingança" de uma "culpa", erro ou transgressão social, que é reparado pela ação de um "vingador". Esse "vingador" exerce 
o papel que a "justiça" (ou a falta dela, como instituição) gera em uma sociedade hierarquizada e violenta, a qual concentra os poderes de toda ordem em um polo dominador e manipulador capaz de criar a própria "justiça" e aplicá-la por meio de seus "justiceiros". Esse é um outro tema valorizado no contexto narrativo do filme de Sérgio Bianchi, que, conduzido pela lente da ironia, subverte todo o empenho altruísta de aparência pelo papel da violência justiceira. Para contracenar com a caridade de superfície e com a função de mantê-la como uma fonte de renda concreta, o filme dá ao papel de "justiceiro" o perfil preciso com que Antonio Candido (1971, p.256) teorizou o seu correlativo social denominado "vingador": "ignora a solidariedade e a igualdade, conhecendo apenas a subordinação e a dependência, requeridas também pelo seu espantoso sadismo”.

\section{"Normalidade social" versus "anormalidade essencial"}

Antonio Candido (1970, p.23), no clássico ensaio "Esquema de Machado de Assis", descreveu o método de composição do escritor, o "tom" ou a sua "matriz formal": "A sua técnica consiste essencialmente em sugerir as coisas mais tremendas da maneira mais cândida (como os ironistas do século XVIII)". Ou seja, na superfície do discurso, a "ironia fina"; na complicação da trama, o mundo turvo do subterrâneo humano ${ }^{1}$ e da sociedade - o "barro humano²."

Assim como o "Candinho" do nome disfarça a brutalidade de que é capaz o personagem no plano da fábula, o "arcaísmo" do "estilo refinado" busca "estabelecer um contraste entre a normalidade social

1 Esse caminho de leitura conduzido pelo "senso do desproporcionado e mesmo o anormal" rumo ao "homem subterrâneo" e às suas ambiguidades, segundo Antonio Candido (1970, p.20), iniciou-se com Augusto Meyer, Lúcia MiguelPereira e Mário Matos. Alfredo Bosi (2006, p.27-33), ao analisar essa versão subterrânea nas leituras do narrador humorista Brás Cubas, acrescenta, ao lado do papel fundamental de Augusto Meyer, a contribuição de Alcides Maia.

2 Expressão destacada por Alfredo Bosi (2006). 
dos fatos e a sua anormalidade essencial", sugerindo, "sob a aparência do contrário, que o ato excepcional é normal, e anormal seria o ato corriqueiro" (ibidem). Dessa maneira, trazendo novamente a justificativa da "máscara" do início do conto, podemos reobservá-la sob esta ótica: "Era grotesca tal máscara, mas a ordem social e humana nem sempre se alcança sem o grotesco, e alguma vez o cruel" (Assis, 1998, p.483). Ou seja, o "ato excepcional" como "normal”. E, na correlação seguinte, o "anormal" vira ato corriqueiro no comportamento social: "Os funileiros as tinham penduradas, à venda, na porta das lojas" (ibidem).

A relação de contrários ou de contradição é uma das chaves de composição machadiana, cujo segredo aproxima disfarçada e sutilmente uma correlação de duplicidade ou os termos de uma oposição num mesmo corpo, como a máscara ao rosto. Isso faz que, no dizer de Antonio Candido (1970, p.17-8), "sob a neutralidade aparente de suas histórias [...] avultam para o leitor atento as mais desmedidas surpresas". Dito de outra maneira, num plano de superfície, a "imparcialidade estilística" da "boa linguagem" corresponde a uma encenação de aparências, graças à qual "a normalidade e o senso das conveniências constituem apenas o disfarce de um universo mais complicado e por vezes turvo" (ibidem, p.20). Essa é, talvez, uma chave de leitura legada e prolongada pelos "aparelhos" da escravidão para a aparência de uma convivência harmoniosa em uma sociedade que disfarça uma base de violência na sua estrutura profunda de diferenças.

O filme de Sérgio Bianchi, de maneira coerente, ilumina esse mundo subterrâneo, projetando toda a carga de violência que aí se manifesta sem a "ironia fina" da película de cobertura, onde reina, intransponível, o estilo machadiano. Como também observou Antonio Candido (1970, p.22), o estilo de Machado é duplo, "arcaico" e "moderno" ao mesmo tempo:

Curiosamente, este arcaísmo parece bruscamente moderno, depois das tendências de vanguarda do nosso tempo, que também procurou sugerir o todo pelo fragmento, a estrutura pela elipse, a emoção pela ironia e a grandeza pela banalidade. 
Como é natural, o filme de Sérgio Bianchi vale-se dessa modernidade que, na verdade, equivale a procedimentos muito próximos do cinema. À outra parte, correspondente ao "estilo refinado", o cineasta vai contrapor o seu estilo provocador, em que os procedimentos do cinema e as possibilidades de sua linguagem não se refinam, mas se afinam a serviço da violência do conteúdo representado.

Como em Machado, a forma procura vestir adequadamente o conteúdo. Mas com uma grande diferença: enquanto o escritor elabora um discurso duplamente irônico, em que a aparência coloca-se no lugar da essência para encenar, nesse papel de falsidade, aquilo que pode ser verdadeiro e, nessa correspondência de contradições, revelar que a verdade pode, às vezes, ocupar o lugar da mentira, o cineasta, com a sua ironia de intenção provocativa, envolve e acua o espectador no cipoal de violência tramado em suas narrativas. Querendo fazê-lo também cúmplice e vítima, o cineasta não faz com o seu espectador aquilo que Machado arma para seu leitor: jogar para aprender as regras do jogo; cair na armadilha do discurso para desarmá-lo; conduzi-lo pela superfície da aparência para surpreendêlo no abismo da essência.

Além dessa relação de contrários, que tem um papel determinante na plasmação de algumas histórias, Machado cria outras mais pontuais, para atender às especificidades do relato dessas histórias. É o casso, nesse conto, da oposição entre os efeitos histórico e ficcional e das correlações de contradição ali apontadas, sempre guiadas pela relação matricial de correspondência entre forma e conteúdo. Se o cineasta Sérgio Bianchi dispensou a película da "ironia fina" para compor uma estética mais agressiva, de acordo com o conteúdo representado em seu filme, dialogou com extrema coerência com vários outros procedimentos discursivo-formais do conto machadiano na operação de transcriação para a linguagem do cinema.

Antes de fazermos esse confronto, buscaremos o fio temático que parece ligar os seus filmes à obra machadiana e que neste, em particular, fica mais ressaltado. Uma das chaves seria, sem dúvida, aquela já revelada por Antonio Candido (1970, p.28), no ensaio aqui tomado como norteador: "Pessoalmente, o que mais me atrai nos seus 
livros é um outro tema [...]: a transformação do homem em objeto do homem, que é uma das maldições ligadas à falta de liberdade verdadeira, econômica e espiritual".

Eleito como "um dos demônios familiares" da obra machadiana, o tema, depois de vários exemplos, é conduzido pelo crítico ao conto "A causa secreta", "onde a relação devoradora de homem a homem assume um caráter de paradigma” (ibidem, p.29), justamente o texto com que Sérgio Bianchi inicia a sua filmografia baseada em Machado de Assis. Na análise de alguns aspectos do conto, Antonio Candido revela importantes frestas por onde o cineasta também pode ter espiado ao perceber as ambiguidades da ironia machadiana, no seu propósito de amplificá-las em seus filmes.

Uma delas se dá no final do conto, cujo fio temático é o sadismo decorrente da condição do "homem transformado em instrumento do homem" (ibidem, p.31), na expressão do crítico, que o cineasta toma como um dos vetores de sua filmografia. Nesse final, analisando o comportamento sádico do personagem, na cena da esposa morta sendo beijada pelo amigo, o crítico conclui que, nessa situação, "o que predomina é o seu prazer com o espetáculo” (ibidem, p.30). Eis uma brecha que os filmes de Sérgio Bianchi exploram: a espetacularização da dor. Isso talvez explique a permuta do estilo discreto, sutil e refinado de Machado, que, no conto em questão, também nomeia de espetáculo a cena do aborto, pelo gritante, violento e espetacularizado do cineasta, como uma forma de ironia e crítica aos tempos atuais de espetacularização das notícias de dor e sofrimento pela mídia de uma maneira geral. Apontar o alvo para as grosserias dos veículos de massa é também uma maneira de o cinema refinar-se.

Quando o crítico diz sobre o escritor "de haver incluído discretamente um estranho fio social na tela do seu relativismo" (ibidem, p.31), parece que o cineasta procurou levar à tela do cinema a ampliação desse "fio social" para destacar uma espécie de "prazer monstruoso", que emerge das camadas profundas dessa estrutura social. Novamente a diferença de estilos e das linguagens. Enquanto em Machado se fia uma tessitura discreta entre o "fio social" e a estrutura de composição, com o fio discursivo articulando-se à estru- 
tura social para incorporar a temática social à filigrana da narrativa como elemento imanente e funcional de composição literária, Sérgio Bianchi joga mais luz, cria mais contrastes e, de acordo com os meios de sua arte, dá mais movimento a essa estrutura social desigual e às perversidades das relações de exploração que ela gera em seu ventre monstruoso.

Enquanto Machado constrói o seu discurso com a capa bemcomportada do estilo para mimetizar no seu relativismo uma aparência de harmonia social, a qual encobre uma desigualdade profunda, Sérgio Bianchi vai justamente dar um contorno mais expressivo ao monstro do sadismo que emerge dessa relação irônica. Para isso, destaca justamente o outro lado do discurso artístico do escritor, aquele elaborado por meio de técnicas que lhe dão modernidade, como o prazer do jogo narrativo sob o comando irônico do narrador. Eis aí duas balizas a serem consideradas na construção fílmica de Quanto vale ou é por quilo?. Só que, em Sérgio Bianchi, o jogo narrativo desencadeia uma duplicação de histórias, uma espécie de narrativa que gera outra e, assim, sucessivamente, enquanto o comando do narrador irônico, seguindo aquela premissa da correspondência entre forma e conteúdo, coloca o seu papel à disposição das histórias, a favor da adequação do modo de narrar em relação à natureza da matéria narrativa apresentada.

Nesse sentido, podemos afirmar que Sérgio Bianchi retrabalhou os dois principais efeitos discursivos propostos por Machado no conto analisado. O início, de indício documental, o cineasta transformou em linguagem e gênero documentários. Enquadrou a história de Candinho nessa linguagem e no tempo da escravidão, emoldurando-a com várias outras narrativas breves desenvolvidas a partir de documentos da Biblioteca Nacional do Rio de Janeiro e com o apoio da obra Crônicas históricas do Rio colonial, de Nireu Oliveira Cavalcanti, também baseada na mesma fonte. Em correspondência à parte do conto marcadamente ficcional, ele traz a "história de uma fuga" para os tempos atuais e reduplica-a em várias narrativas entrelaçadas. $\mathrm{Ou}$ seja, não só recriou a estratégia de Machado, como machadianamente incluiu a ficção da "caçada" no gênero documentário e a duplicou, 
no presente, na parte marcadamente ficcional do filme, para captar o seu reflexo com as lentes da atualidade no espelho da realidade social.

A estratégia fundamental do filme não é apenas transcriar o conto na linguagem do cinema. Mais do que isso, é, com inventividade de linguagem, reduplicar o argumento daquela narrativa em outras histórias atuais, deslocando uma situação do passado para o presente, e mostrar, de várias perspectivas narrativas, como ainda persistem as marcas e as injustiças da época da escravidão no corpo social de hoje. Nesse sentido, o grande mérito do filme é promover essa estratégia de deslocamento, em que os argumentos narrativos situados em um período histórico, social e econômico escravocrata podem ser reconhecidos no contexto social e capitalista atual.

A segunda estratégia foi investir nas potencialidades dos dois efeitos discursivos principais do conto, reduplicando histórias de corte documental e criando outras, do lado da ficção, enquadradas no contexto brasileiro contemporâneo. Para isso, o cineasta também permutou o foco narrativo de primeira pessoa por uma focalização de terceira pessoa. Perdeu o desempenho irônico do narrador literário, mas potencializou, na natureza e nas estratégias de suas histórias em terceira pessoa, uma ironia muito mais crua e feroz, de acordo com a brutalidade do conteúdo que coloca em cena. Assim, promove uma outra grande mudança: desloca o foco da história do personagem Candinho para eleger como eixo narrativo a protagonização do personagem Arminda. Por meio desse procedimento, desloca de foco o lugar social - do território do "caçador de escravos" para o vértice do "escravo" - e justifica a permuta do ponto de vista, cuja objetividade e maior distanciamento permitem um retrato mais contundente da violência mostrada. Por isso, também a sua ironia é mais cortante e surge dos cortes promovidos pelo processo de montagem, que entrelaça os diversos planos e sequências dessas histórias duplicadas.

O início do filme já lhe dá o tom. Mistura créditos, que são da natureza dos bastidores e da metalinguagem do filme, com ficção: música de fundo e vozes da narrativa que vai insurgir. A ironia instala-se para assumir o comando: os créditos são de patrocínios dos órgãos financiadores do longa-metragem, revelando, nessa "mistu- 
ra" e ordem invertida, que o filme depende do "favor" desse poder financiador. Assim como o seu leitmotiv - a exploração da miséria social -, a enunciação coloca o filme como vítima e dependente do controle de um poder cultural.

A primeira sequência revela a estratégia adotada de reforçar o efeito documental, desenvolvendo uma história, com os recursos estilísticos de envelhecimento, retirada dos arquivos da Biblioteca Nacional. A voz em off narra o que as cenas escurecidas mostram: uma negra alforriada, proprietária de uma chácara, é roubada em uma expedição de capitães do mato promovida por um proprietário vizinho, rico e branco. Ela tenta resgatar o escravo confiscado, utilizando seus direitos e documentos, mas é julgada e presa por perturbação da ordem social. A pequena narrativa é concluída por uma espécie de moldura, em que uma explosão de luz congela a última cena preparada ironicamente, pois desmente o ocorrido na sequência fílmica, como uma fotografia da época, que resume aquela história com os créditos do documento: "1799, Rio de Janeiro, vicereinado, caixa 490".

A ironia, como se vê, surge de dois modos. No plano do conteúdo, a inversão da ordem e dos direitos: a negra alforriada e proprietária é roubada e, ainda, condenada. No plano da forma, além de ampliar o que é sugerido no conto, o cineasta adota uma linguagem e um gênero apropriados ao efeito histórico e mostra, na relação metalinguística entre o cinema e a fotografia, como a dinamicidade do filme pode dar vida ao arquivo morto e desconstruir, ao mesmo tempo, a pose falsa da História, sempre vista da perspectiva do poder e da dominação. Essa correlação lembra outro lance machadiano, em uma estratégia aproximativa de seu discurso: dar vida ao arquivo, num plano profundo, é também uma maneira de fazer o "subterrâneo" do passado emergir no presente do discurso do cinema. No filme, essa ironia mais refinada é tramada pela função da metalinguagem. Da mesma maneira, via metalinguagem, o filme vai parodiar e ironizar a linguagem da propaganda, expondo o apelo da função emotiva desse discurso que se apresenta infiltrado na trama. Nessa mistura de gêneros, entra, ainda, um terceiro, de efeito retórico burocrático, 
cifrado na linguagem jurídico-econômica dos códigos institucionais em que são gestados os projetos de assistência social. Esses discursos emaranhados, como veremos, vão representar segmentos da sociedade, desempenhando importantes funções tanto no plano da forma quanto no do conteúdo, valorizando artisticamente os aspectos da ficção que ajudam a compor.

Após a "fotografia" que fecha aquela primeira narrativa encaixa$\mathrm{da}$, surgem, em silêncio, o título do filme e a assinatura do diretor - o comentário metalinguístico que convoca a participação do leitor. No ritmo lento de um canto, são apresentados os "aparelhos" referidos no conto, em cenas fortes, colocando, em primeiro plano e close, os instrumentos e seus efeitos acrescidos das descrições e dos comentários adaptados do conto. Assim é marcado para o espectador o eixo da protagonização: a mesma atriz que faz o papel da negra roubada, agora veste a terrível máscara de folha de flandres, nessa sequência torturante, e, em seguida, com o corte e a entrada brusca de um samba ("As rosas não falam", de Cartola), Arminda, ainda sob o efeito do sono ("E, quem sabe, sonhava meus sonhos"), sai desse passado para acordar no presente. Na favela, no giro de uma roda de samba, a câmera passeia por uma festa, o aniversário de Dona Judite, mãe de Lurdes e tia de Arminda, o trio que terá um papel importante na trama, como vítima do mecanismo de corrupção situado entre as outras duas pontas da cadeia social: a dos pobres explorados e a da elite exploradora da miséria.

Por meio de um efeito de fusão, entra um comercial com imagens de crianças abandonadas, que fazem parte de um anúncio de "teledoação", da empresa "Sorriso de Criança", cujo logotipo na tela relativiza os limites de gêneros (ficção, documentário e propaganda) e meios aí implicados: cinema e TV. Continuando o processo de "mistura", segue uma reunião burocrática, em que os profissionais de uma empresa especializada em projetos de filantropia discutem com o cliente do anúncio veiculado as propostas de mudança de enfoque e apelos para os novos comerciais. O enfoque é empresarial: "quem financia solidariedade, hoje quer um retorno"; as funções emotiva e apelativa devem resultar de "depoimentos emocionados", ensina o 
diretor da agência, o Sr. Marco Aurélio dos Santos, para quem "doar é um instrumento de poder”. A sucessão dessas sequências é construída coerentemente com as linguagens dos três gêneros referidos: documental para o conteúdo histórico; da publicidade para explorar a criança pobre como um produto; o jargão econômico-empresarial para fazer da pobreza um produto lucrativo.

A sequência seguinte apresenta a construção de um anúncio colocando em ação o formato retórico-ideológico vendido anteriormente. Uma representante da elite, Marta Figueiredo, num flagrante de sua "dieta de consciência", posa entre crianças agrupadas com os brinquedos doados, no centro da fotografia irônica, que, ao destacar a organização da pose, lembra a foto que emoldura o episódio histórico do início, simulando, nesse gesto e com o meio fotográfico, a presença do passado no presente do filme. A imagem, acompanhando o disparo de uma câmera fotográfica, é congelada em uma explosão de luz, apagada e devolvida instantes depois (num movimento irônico de doação e retorno similar ao do investimento empresarial em jogo) na claridade e no movimento do escritório do Sr. Marco Aurélio.

O diálogo entre o empresário e a sua cliente prepara a entrada das três últimas sequências que concluem essa primeira parte do filme. Elas reforçam, com a introdução de novos personagens e suas significações, as três pontas da estrutura social implicada na trama: a elite beneficiária da exploração da miséria; os pobres utilizados como o produto do negócio; os elementos de intermediação entre os dois polos. Desnudam também um pouco dos mecanismos de duplicação formais e de conteúdo, que reduplicam personagens e histórias sempre ligadas e amarradas, em efeitos de linguagem apropriados, a essa estrutura social de base.

A primeira sequência introduz uma cena de rua, madrugada, em que duas "caridosas" disputam o espaço de distribuição de donativos e cobertores. A dona do ponto, Noêmia, expulsa a concorrente e, durante a ação de seu grupo, uma de suas ajudantes, tia Mônica, vê passar, com o caminhão de lixo, o seu futuro genro, Candinho. Por meio dessa estratégia, com o motivo do casamento, a "história de uma fuga", do conto, é introduzida no filme. Pensando em como 
conseguir dinheiro para a festa do casamento, há um corte e, com a entrada do slogan do novo comercial, "vencendo com o social", tia Mônica passa a protagonizar a segunda sequência.

Trata-se de um comercial biográfico em que o drama da "dignidade esvaziada" de Mônica Silveira é resolvido com a descoberta de sua vocação e prazer em ajudar as pessoas. De ajudante, funda a sua própria associação e descobre que "a vingança é um prato que se come frio", mas "o altruísmo é um prato mais saboroso". A função dessa sequência intermediária é irônica, e, por isso, o próprio comercial deixa ver os bastidores da filmagem, cujo desmascaramento metalinguístico inverte as posições entre tia Mônica e Dona Noêmia, sugerindo que esta passa a ser ajudante daquela. Mas trata-se de um sonho.

Acordada pela realidade do comando de Noêmia, Mônica Silveira aceita o convite para trabalhar em tempo integral para a sua comandante, persuadida pela proposta de adiantamento do dinheiro necessário para a realização da tão desejada festa de casamento. A conclusão dessa última sequência, uma espécie de síntese dialética, realça os elementos temáticos que irão ecoar ao longo do filme, no seu processo de reduplicação: a vingança e o altruísmo; a dívida e a dependência; a dependência do "favor".

\section{O triângulo social: movimentos de leitura}

Pode-se dizer que o conto "Pai contra mãe" representa literariamente um fato histórico-social, o nascimento do "homem livre" na sociedade escravista do Brasil colonial. Roberto Schwarz (1977, p.16), que o estudou, articulando-o ao "mecanismo do favor", e demonstrou suas implicações em obras de Machado de Assis, descreveo da seguinte maneira no texto "As idéias fora do lugar":

Esquematizando, pode-se dizer que a colonização produziu, com base no monopólio da terra, três classes de população: o latifundiário, o escravo e o "homem livre", na verdade dependente. Entre os 
primeiros dois a relação é clara, é a multidão de terceiros que nos interessa. Nem proprietários nem proletários, seu acesso à vida social e a seus bens depende materialmente do favor, indireto ou direto, de um grande. $\mathrm{O}$ agregado é a sua caricatura.

Candinho veste com muita propriedade o figurino do "homem livre", essa figura-síntese que encarna a contradição de ser "livre" em relação à classe escravizada, mas "dependente" material e socialmente do favor do senhor. A sua ambiguidade é resultante desse movimento dialético, que gera uma "terceira margem" nas relações da estrutura socioeconômica e ideológica do período. Ao ficcionalizar, no conto, o mecanismo do favor, juntamente com a configuração desse novo espaço social, Machado descreve a trajetória de um movimento histórico, que se desdobrou em múltiplas ocorrências socioculturais. Acompanhando a representação desse deslocamento, podemos estabelecer um movimento de leitura correspondente, que surge da confrontação dialética dessa estrutura social, mas que, a partir da síntese, pode fazer todo o triângulo girar, encadeando, na dinâmica de suas direções, novas e complexas relações de sentido. É apoiado nesse deslocamento e no engendramento dessa dinâmica e suas possibilidades de leituras que Sérgio Bianchi estrutura seu filme, tomando-o como o eixo de partida e gerador do mecanismo multiplicador de histórias.

O efeito de deslocamento do início do conto, de simulação histórica, para o desenvolvimento do núcleo ficcional, deve ter conduzido o traçado do roteiro do filme, que dá movimento a esse deslocamento e, por meio dele, permite-nos também adotar uma direção de leitura. Por meio dessa estratégia, o filme "documenta" a parte dos "ofícios e aparelhos" e, com a mesma retórica e recursos desse discurso histórico, desenvolve a "história de uma fuga', com personagens e ambientação da época. Em correspondência à parte de domínio ficcional, recria outra história de fuga, em que o personagem Candinho, a serviço de um comerciante, mata Damião e Ratinho e atualiza a história de Arminda, que agora também está grávida, mas, no lugar do aborto, é morta. Esses dois efeitos e núcleos do conto, além de 
duplicados no filme, são os pontos de partida para os argumentos das outras histórias inseridas, tanto aquelas situadas no contexto escravocrata quanto as inventadas dentro de um panorama social contemporâneo, visto como uma realidade modificada, mas prolongada do passado. Nessas histórias, o jogo do poder, da dominação e exploração social, originário da estrutura triangular colonial, gera uma rede intrincada de sentidos.

O conto de Machado desenha as linhas do triângulo, apresenta, nas diretrizes de seus ângulos, uma configuração da espacialidade social e esboça, a partir do contorno dos tipos estabelecidos nos antigos territórios, o perfil do novo e promissor figurante social. Um dos mais ilustres representantes dessa linhagem, o malandro Leonardo, das Memórias de um sargento de milícias, foi estudado por Antonio Candido (1993) no texto "Dialética da malandragem", considerado a matriz das leituras críticas que emergem dessa estrutura originária. O Candinho de Machado, por sua vez, vestindo a pele de um "caçador", representa, nas trilhas de sua "caçada", o deslocamento de um percurso social polarizado ( $a$ e $b$ ) para a instauração de uma estrutura triangular $(a, b$ e $c)$. No conto, esse deslocamento se dá, primeiramente, do vértice $b$ para o $c$, ou seja, com a fuga da escrava até a sua captura; depois, do vértice $c$ para o $a$, com o retorno à casa do proprietário, o senhor de escravo. Em outras palavras, Machado redesenhou a estrutura da sociedade escravista, mostrando, no alto de sua pirâmide, a instalação do proprietário na "casa-grande". $\mathrm{Na}$ "senzala", sua contiguidade, o espaço do escravo; e encenou, como extensão dessa tensão de dominação e poder, a instauração de um sistema intermediário funcionando como um mecanismo regulador, o qual gerou a irregularidade "regular" do "homem livre".

O filme de Sérgio Bianchi apresenta algumas dessas possibilidades gestadas na escravidão e desenvolvidas nos interstícios do complexo espaço social contemporâneo brasileiro. Ou seja, veste e coloca em ação a expressão certeira cunhada por Schwarz (1977, p.16) para caracterizar essa maleabilidade do mecanismo do favor: "com mil formas e nomes, o favor atravessou e afetou no conjunto a existência nacional, ressalvada sempre a relação produtiva de base, 
esta assegurada pela força". Na versão da "história de uma fuga" correspondente ao conto, contextualizada no passado histórico, a dramatização da "caçada" coloca o personagem Candinho no paradigma do "capitão do mato". No deslocamento desse motivo para o contexto contemporâneo, Candinho encena o papel de "justiceiro". No primeiro episódio representado, a mando (ou "favor") de um comerciante, vinga e mata dois favelados infratores. Depois, nas mesmas malhas dessa rede social, "caça”, mata e vinga a grávida Arminda. Unindo o passado e o presente, esse personagem sente na pele as marcas do prolongamento das "injustiças" de um sistema social. Colhendo a ironia plantada por Machado, por três vezes, no filme, Arminda sentiu-se "desarmada" para lutar contra a violência e corrupção desse sistema prolongado da escravidão.

\section{O espaço em movimento}

Partindo da estrutura triangular do conto, o filme veste-a com peculiaridades discursivas para dar forma aos conteúdos de suas interfaces: o vértice $a$, com o jargão ideológico-empresarial da elite; o vértice $b$, com o efeito documental e histórico que vem da escravidão para simbolizar a pobreza, agora representada por crianças abandonadas e adultos doentes; no vértice $c$, representando a intermediação entre os dois, a linguagem da publicidade surge como descendente da ambiguidade do "homem livre" e "caçador de escravos" para alavancar as ONGs, uma instituição moderna gerada por esse sistema e que se apresenta como síntese dessas contradições: disfarça, na linguagem da propaganda, o sentimentalismo e a emotividade dos desvalidos que encobrem a praticidade e ferocidade do lucro empresarial; nomeia-se não governamental, mas é oficializada e reconhecida para desempenhar um papel institucional. O filme, conduzido por um discurso artístico-ficcional, globalizador e condutor dessas várias esferas de linguagens e ideologias, dá movimento a essa estrutura matricial, modernizando-a pelas várias facetas e situações geradas nos interstícios das relações potencializadas entre os seus vértices. 
Da mesma maneira que seu conteúdo, o filme transita do documentário ao ficcional, passando pela publicidade para obter, na síntese, o ganho de seu desempenho estético. Trabalhando essas variações discursivas, retrata um sistema desigual e injusto, que se movimenta entre o lucro e a miséria, por meio do papel duplo e hipócrita do altruísmo. Representando esse papel, as ONGs surgem como "máscaras" atuais, que ligam a miséria à fortuna, fazendo da caridade um investimento lucrativo. Situadas entre esses dois extremos, as ONGs abrem-se como um leque que abana o sentimento de culpa e areja as consciências, tentando equilibrar a discrepância desse peso secular. Por isso, definidas as características de cada uma das pontas da estrutura triangular, podemos considerá-las como lugares sociais que o filme faz girar, descrevendo, com as histórias e as linguagens que executam os seus movimentos, um percurso crítico que se abre para a atualidade como um panorama da violência entranhada em nosso cotidiano de várias formas: mais explícita, simulada ou insidiosamente integrada em uma convivência disfarçada em naturalidade.

Para contar a história da Arminda, desde a sua gestação na escravidão até a sua morte, num espaço e tempo que sugerem a continuidade daquela época, o fio central da narrativa, quebrado e emendado por outras pequenas histórias, é conduzido também por meio de grandes quadros ou episódios. Assim, depois da primeira parte, impulsionada pela sugestão mercantil do título do filme, sucedem mais cinco episódios com títulos irônicos em relação aos seus temas.

O primeiro deles, "História de uma grande amizade entre Maria Antônia e Lucrecia”, contextualizado na época da escravidão, apresenta a Maria Antônia do título - ancestral da Dona Noêmia já conhecida -, uma pequena negociante de escravos, vendendo suas "mercadorias" a pessoas mais ricas. Ou seja, a sua intermediação leva o escravo ao grande e rico proprietário. Mas, na pequena história que dá título ao episódio, "extraída do Arquivo Nacional, R. J., $4^{\circ}$ Ofício de Notas, livro 104, 16 de setembro de 1786", o deslocamento espacial descreve um movimento contrário: Maria Antônia do Rosário compra a alforria da escrava Lucrecia, explorada e maltratada pela família Pereira Cardoso, por "34 mil réis". Trabalhando exces- 
sivamente para a nova patroa e terceiros, Lucrecia, depois de dois anos, junta "42.238 réis", conseguindo pagar a alforria empenhada e possibilitar um lucro de "8.238 réis" à "amiga", cujo investimento superou os juros calculados no negócio. Com a fotografia que faz o papel de moldura e devolve Lucrecia ao vértice do escravo, agora alforriado (a nova casa do pobre brasileiro), a história é fechada com a chave da legenda irônica: "amizade, liberdade, solidariedade".

Depois do silêncio da fotografia, a tela escurecida do passado é devolvida com as luzes e o movimento do presente, para acompanharmos a tramitação moderna desse papel de intermediação. $\mathrm{Na}$ empresa do Dr. Marco Aurélio, o símbolo maior desse mecanismo no filme, Dona Judite, a tia de Arminda, após um derrame, atua como faxineira e pede ao patrão um dinheiro para poder visitar o filho que está na cadeia. Em novo corte, na periferia, a equipe do Dr. Marco Aurélio e o vereador Sólis inauguram o "Centro de Informática", o projeto de inclusão digital nuclear da narrativa, pois o seu esquema de desvio de verbas está acobertado no nome de Dona Judite e sua descoberta e denúncia vão causar, como consequência, a morte de Arminda no desfecho do filme.

Para percorrer esse longo caminho, a trama vai apresentando pequenos quadros que ampliam as dimensões desse esquema de corrupção e exploração. É o caso do "Projeto Alegria", em que senhoras da elite propiciam passeios e jantares a crianças doentes. Num desses encontros, em um restaurante, Arminda é mais bem esclarecida sobre os esquemas de superfaturamento que atuam para a permanência da miséria e resolve lutar para ter de volta os computadores quebrados durante a inauguração do projeto na favela. No quadro seguinte, Arminda assiste à preparação de um comercial com crianças negras e vê, no tratamento bruto e preconceituoso dos profissionais de filmagem, a sombra do passado em imagens com o desfile dessas crianças amarradas. Em novo quadro, o núcleo narrativo do conto está de volta, com os preparativos do casamento. Chega Dona Noêmia, a financiadora da festa e, juntamente com o presente, traz a cobrança do "favor": a sua associação mudou-se para uma chácara no interior e ela precisa de Mônica lá, em tempo integral. Em um dos movimentos 
mais significativos do filme, tia Mônica dirige imediatamente o olhar para o chão, indicando a filha negra adotiva para o seu lugar. Na cena seguinte, já estamos no interior, dentro de uma das sequências mais deprimentes, em que mendigos e doentes são filmados tomando um “composto natural e divino", a poção nojenta e milagrosa que deve arrancar o patrocínio da empresa "Fhilantropic Partners".

Em outro espaço, os aplausos de um seleto auditório premiam os efeitos da poção, mas a glória principal de "inovação solidária", o "Prêmio Estímulo de Braço Direito da Solidariedade", é dada pelo presidente das "Associações Reunidas" ao idealizador do "Manual de Captação de Recursos", um guia de instruções para se ter acesso aos fundos governamentais de cunho social. Essa sequência é continuada por outra, que funciona como o seu contraponto irônico. Em tom documental, cifras e números traçam um retrato da quantidade dessas entidades assistenciais e os gastos de infraestrutura e manutenção que poderiam ser investidos, sem os desvios das intervenções, aplicados diretamente em moradias e escolaridade para as crianças abandonadas. A contundência dessa denúncia é feita por meio de fotografias de crianças emolduradas em quadros, cuja sequência, cada vez mais rápida, imprime tensão e nervosismo a essa cadeia de descontrole e desperdício de verbas públicas. O contraponto artístico é dado pelo ritmo lento da cena seguinte, em que um canto religioso, na sua melodia de lamento, funde a imagem de uma catadora de lixo ao rosto de Arminda com a máscara de folha de flandres. Aqui o cinema se impõe, soberano, no exercício de sua linguagem dramática e estética, com toda a sua carga poética.

O episódio seguinte, "A denúncia como negócio", o mais curto deles, funciona como o instaurador do conflito principal, o núcleo desencadeador da "vingança" e morte de Arminda, a história inventada no presente em correspondência ao passado do conto. A denúncia está, ainda, no plano das ameaças: Arminda, sabendo das irregularidades dos projetos assistenciais, quer a reposição dos computadores na favela e ameaça Ricardo, o braço direito do Dr. Marco Aurélio. Ricardo, por sua vez, ameaça Arminda, que pode perder o emprego e ainda prejudicar o andamento de outros projetos. 
Passando por cima da ameaça de Arminda, Ricardo, na próxima cena, dá folga e ajuda com dinheiro a tia de Arminda, Dona Judite, para que esta possa visitar o filho na cadeia. O preço do "favor" surgirá, depois, com a assinatura de "papéis" por Dona Judite. Mas a outra forma de denúncia que o filme quer revelar é a indústria da construção de presídios, em toda a sua cadeia de movimentação da economia. Totalmente desumanizado, o sistema carcerário é retratado, no final, em cenas fortes, nas celas totalmente lotadas e paralisadas como metáforas irônicas dos navios negreiros: "na época da escravidão a gente era tudo máquina; agora somos escravos sem dono", diz o filho de Dona Judite. Nessa realidade duplicada na atualidade, o episódio reafirma a situação histórico-social daqueles que são imobilizados no vértice $b$ da pirâmide para a economia movimentar-se por meio da ação dos intermediadores (vértice $b$ ), em benefício dos verdadeiros donos dos "novos escravos" (vértice a).

Formando a quarta parte do filme, o episódio "História de Bernardino e Adão", extraído do "Arquivo Nacional, Tribunal da Relação, 1797, livro 12”, propicia um movimento significativo nas relações entre os espaços sociais. Descrevendo uma trajetória de inversão em relação ao anterior, o conflito vai estabelecer-se no vértice $a$, ou seja, no interior da classe dos proprietários.

O Sr. Bernardino aluga seu honesto e competente escravo Adão ao Sr. Sebastião Soares, para organizar a contabilidade de sua fábrica de mate. Adão é acusado de roubo, surrado e detido como indigente em uma cadeia pública. O seu dono resgata-o, paga os 27.000 réis do roubo forjado e mais a fiança, totalizando um gasto de 47.000 réis . Em seguida, processa o Sr. Sebastião, prova o golpe, ganha a causa e, com a indenização de 60.000 réis, lucra 13.000 réis na conclusão do negócio.

A foto que emoldura a sequência apaga-se, e o filme devolve-nos o presente, com o conflito instalado, agora, no núcleo familiar transposto do conto, com Glorinha esperando um filho, mas totalmente cooptada pelos sonhos de consumo da realidade de outra classe. Tia Mônica prepara doces e salgadinhos para festas e cobra de Candinho um emprego mais seguro. Ameaçado pelos desejos da esposa e pela cobrança da tia, Candinho resolve "voltar às antigas", ou seja, exercer a função de "justiceiro" no lugar da polícia. 
Em oposição ao conflito anterior, instalado no alto da pirâmide social, com o retorno da protagonização de Candinho, que vinga Ratinho e Damião, e, depois, no papel de capitão do mato da história adaptada do conto, o foco da narrativa desloca-se para o vértice $c$, contextualizado como o lugar social dos "trabalhadores autônomos" ou dos "serviços terceirizados". No lugar daquela disputa declarada, tem-se, agora, um conflito também irônico, mas menos explícito, desenvolvido na "guerra" pelo ganho dos serviços terceirizados da "justiça" aplicada sobre aqueles que se situam no vértice $b$. No passado do contexto do conto, Candinho disputava com outros concorrentes as recompensas pela captura de escravos fugidos. No presente da narrativa do filme, Candinho disputa a captura de adolescentes marginais e crianças abandonadas com a própria polícia. É o que sugere a articulação entre as três últimas sequências dessa parte: a "caçada" de Candinho aos jovens Ratinho e Damião, a serviço de um comerciante; a bela tradução do conto, na montagem e nos efeitos de época, do episódio de captura da Arminda; a cena final, de madrugada, com policiais recolhendo crianças abandonadas nas ruas com um camburão.

A parte seguinte, "O aprendizado do novo mercado", começa em um cenário de aula, com uma equipe sendo instruída para aprender a elaborar projetos de captação de recursos para fins assistenciais. A função metalinguística explícita da cena amplia a ironia dirigida à proliferação dessa indústria de assistencialismo. Como contraponto a esse espaço bem equipado e organizado, as cenas seguintes intensificam a ironia, mostrando o ambiente decadente e de abandono em que vivem idosos precariamente cuidados em um asilo.

Em outra relação irônica entre discursos e linguagens, procedimento recorrente no filme, por meio do discurso da publicidade, o Dr. Marco Aurélio anuncia um novo "projeto vencedor", tendo como alvo empresas que queiram investir em responsabilidade social. A mensagem transita do filme para a TV e sua imagem é utilizada para o planejamento de um sequestro. Sob o comando de Dido, o filho de Dona Judite, a quadrilha esquematiza o plano anunciado como de "terror forte", para ser executado em um "cenário de guerra".

Em novo corte, no interior da agência, Lurdes discute com Ricardo Pedrosa sobre a recusa de seu projeto de captação. Lurdes é 
demitida e leva os papéis da empresa que comprovam o esquema de corrupção do projeto de inclusão digital: desvios de verbas, notas forjadas e a revelação da conta no nome de Dona Judite. Com a posse desses papéis, Arminda, grávida, arma o seu plano de "vingança".

Analisando o conjunto dos fatos, pode-se dizer que o sentido principal do episódio indica duas tentativas de inversão de uma situação social já cristalizada. O filme, a partir do conto, impulsionado pelo mecanismo do favor, vinha denunciando o esquema secular da elite em utilizar-se de meios de intermediação como forma de manutenção de poder e enriquecimento. Dido, como prisioneiro e marginal nessa escalada triangular, inicia um movimento contrário e revolucionário: coloca-se contra o vértice $a$ e a favor do $b$. Arminda, encarnando a figura da escrava fugida, tenta, na narrativa do presente, executar o seu projeto de "vingança", ou seja, deslocar-se do $b$ para o vértice $c$, como uma saída da casa secular historicamente explorada.

O último episódio, "A ponte sobre o abismo social", desenvolve os desfechos dessa rede lançada de vinganças. As primeiras imagens acompanham o casal Marco Aurélio e esposa, da empresa para a residência, enquanto a voz em off de Dido explica que saiu da cadeia pagando, a forma de investimento para desenvolver a sua função social, o sequestro, a maneira de "fechar o ciclo para o dinheiro circular”. A ponte de via única metaforizada por Marco Aurélio, portanto, é ameaçada por outra, de represália social, de via contrária.

Do espaço rico do apartamento em que ocorre o sequestro, a ação desloca-se para cubículo escuro do confronto discursivo-ideológico entre sequestrador e sequestrado: a voz da periferia contra a voz empresarial do comercial; a comunidade utilizada como mercadoria contra o lucro por ela gerado com os empreendimentos comunitários e a situação de inversão, o "caçador" que se torna "caça". Após esse embate "dialógico", ${ }^{3}$ Marco Aurélio é amordaçado e ameaçado com

3 Embora os conflitos entre personagens de classes sociais diferentes sejam permanentes no andamento do filme, é a partir dessa cena e, depois, no salão do Teatro Municipal que o confronto de vozes se realiza, trazendo para o primeiro plano o debate dialógico no sentido teorizado por Bakhtin (2005, p.212), de "cruzamento e interseção de duas consciências, de dois pontos de vista, de duas avaliações" a partir de duas esferas de linguagens e lugares ideológico-sociais diferentes. 
as partes do seu corpo como forma de pressão para o pagamento do resgate.

Em novo corte e contraste, a imagem focaliza o imponente Teatro Municipal do Rio de Janeiro, em que ocorre a cerimônia do "IV Prêmio Selo de Qualidade de Empreendimentos Assistenciais”. A voz em off do sequestrador sobreposta às imagens da cerimônia expõe o seu ponto de vista: "o sequestro é um negócio moderno. Precisa de violência porque ele funciona como propaganda para estimular a negociação, pois o que importa nesses dias é o business, o marketing, a livre iniciativa". A continuidade de seu discurso - "sequestro nãoé só captação de recursos; é também redistribuição de renda" - amplia a ironia, pois sua voz, agora, sobrepõe-se à imagem de uma criança do comercial veiculado no auditório da premiação. O comercial termina com o seu comando apelativo - "clique e escolha os destinatários de suas doações" - e a assinatura do projeto: "consciência. org. o portal da cidadania".

Os aplausos coroam o lançamento de mais uma ação da empresa de Marco Aurélio e premiam o idealizador do projeto, Ricardo Pedrosa, que, por sua vez, dedica o prêmio ao líder e fundador da empresa. O tom sério da cerimônia é quebrado com a cena carnavalizada da imagem do vencedor com a orelha mutilada e sua fala cínica: "O que é uma orelha comparada a milhares de pessoas que a gente ajuda?".

Do cômico das risadas, os discursos retomam o tom sério da cerimônia para desencadear o dramático da sequência que se inicia com a chegada de Arminda e um grupo de pessoas para denunciarem os esquemas irregulares da empresa homenageada. Acuado, Ricardo Pedrosa não tem muito o que fazer a não ser convidar os invasores para a festa de cerimônia, enquanto Arminda denuncia à TV todo o esquema, citando as pessoas envolvidas, a tia utilizada como "laranja" e os papéis como provas comprobatórias. Em contrapartida, Ricardo anuncia a "vingança": "é preciso dar um jeito nessa mulher".

A trilha sonora das sequências de captura retorna para efetivar a derradeira "caçada": Candinho mata Arminda. No lugar do aborto, mãe e filho morrem. O recurso da fotografia corta e encaminha a cena 
para o interior da casa de Candinho, o qual, juntamente com a tia, a esposa e o filho, comemora a recompensa. Outra fotografia fecha o filme com a ironia da imagem da festa doméstica e o retorno da voz em off trazendo o eco do conto: "com a recompensa pela escrava fugida, o capitão do mato pode agora criar seu filho, alimentá-lo e educá-lo com dignidade e liberdade”. O título e o início dos créditos indicam o final do filme, mas ainda somos surpreendidos com o recurso da duplicidade em uma última chave machadiana. A cena da "caçada" é reapresentada. Arminda propõe a Candinho um acordo de "vingança": dividir o dinheiro do projeto, montar uma central de sequestro, enfim, aplicar a violência contra os que roubam o Estado.

Terminado o filme, o leitor de Machado de Assis e espectador de Sérgio Bianchi pode, ainda, completar essa trajetória com outra trilha paralela. A proposta do crítico João Cezar de Castro Rocha (2004), que, em correspondência à "Dialética da malandragem", formulada por Antonio Candido (1993), apresenta os caminhos de uma "Dialética da marginalidade". Segundo Castro Rocha (2004, p.8), enquanto aquela abordagem aceita ainda uma convivência pacífica com o malandro no processo de relação entre as classes, para a dialética da marginalidade "não se trata mais de conciliar diferenças, mas de evidenciá-las". Nesse sentido, a produção cultural contemporânea solicita um modelo de interpretação mais radical, em que o termo "marginal não possui conotação unicamente pejorativa, representando também o contingente da população que se encontra à margem, no tocante aos direitos elementares, sem dispor de uma perspectiva clara de absorção, ao contrário do malandro" (ibidem).

Não se trata, porém, da substituição de uma proposta por outra: são duas trilhas que se complementam, tendo em comum o traço sempre persistente da violência. Essa trajetória da violência é a mesma: da malandragem à marginalidade; do escravismo ao capitalismo; do conto ao filme, como a leitura de Sérgio Bianchi demonstra. No quadro desse processo histórico-social, a violência configura, movimenta e dá sentido a essa espacialidade social. 


\section{Referências bibliográficas}

ASSIS, M. de. Pai contra mãe. In: Contos: uma antologia. Seleção, introdução e notas John Gledson. São Paulo: Companhia das Letras, 1998. v.2, p.483-94.

BAKHTIN, M. Problemas da poética de Dostoiévski. Trad. Paulo Bezerra. 3.ed. Rio de Janeiro: Forense Universitária, 2005.

BOSI, A. Brás Cubas em três versões: estudos machadianos. São Paulo: Companhia das Letras, 2006.

CANDIDO, A. Esquema de Machado de Assis. In: Vários escritos.

São Paulo: Livraria Duas Cidades, 1970. p.13-32.

Da vingança. In: Tese e antítese. São Paulo: Companhia Editora Nacional, 1971. p.1-28.

Dialética da malandragem. In: O discurso e a cidade. São Paulo: Duas Cidades, 1993.

PIRANDELLO, L. O humorismo. Trad. Dion Davi Macedo. São Paulo: Experimento, 1996.

ROCHA, J. C. de C. Dialética da marginalidade: caracterização da cultura contemporânea. Folha de S.Paulo, São Paulo, 29 fev. 2004. Mais!.

SCHWARZ, R. Ao vencedor as batatas. São Paulo: Duas Cidades, 1977.

\section{Filmografia}

A CAUSA secreta. Direção de Sérgio Bianchi, 1994. 97 min, color., son., DVD.

QUANTO vale ou é por quilo? Direção de Sérgio Bianchi, 2005. 108 min, color., son. DVD. 


\section{6 \\ FOLHETINS D'AQUÉM E D'ALÉM-MAR: A FORMAÇÃO DA CRÔNICA NO BRASIL}

Lúcia Granja*

\section{No rodapé dos jornais}

Ao longo do século XIX brasileiro, o rodapé dos jornais abrigou os romances-folhetim, principalmente traduzidos das páginas dos jornais franceses. "Por que o sucesso [do romance-folhetim] em longínquas plagas, onde não existe ainda a cidade grande, de uma fórmula tão ligada a certo momento social francês, europeu?", perguntou-se anteriormente Marlyse Meyer (1996, p.33). E o testemunho de José de Alencar (1990, p.29), em Como e porque sou romancista, ajudou-nos a compreender que, nos serões familiares, mesmo antes da chegada do folhetim, se fazia uma "leitura contínua e repetida de novelas e romances", mesmo se o "repertório romântico [...] compunha-se de uma dúzia de obras, entre as quais primavam Amanda e Oscar, Saint-Clair das Ilhas, Celestina e outras de que já não me recordo". Dessa forma, na França, mas também no Brasil, a fórmula inventada por Émile de Girardin para La Presse, com o objetivo de expandir comercialmente o jornal, teve sucesso, pois

* Doutora em Letras pela Universidade Estadual de Campinas (Unicamp) e professora-assistente da Universidade Estadual Paulista (UNESP), campus de São José do Rio Preto. 
"já respondia a hábitos adquiridos de leitura ou audição de ficção" (Meyer, 1996, p.24). E se no Brasil o folhetim "pegou” tão bem foi porque encontrou terreno favorável: às leituras tradicionais, tinham sucedido as "galantes novelas todas traduzidas do francês" (ibidem, p.34). A partir daí, sabendo que também a crônica se estruturou no rodapé dos jornais, como passamos de uma a outra forma textual?

Essa é, justamente, a longa história com a qual este texto pretende colaborar. Hoje em dia, a crônica é muitas vezes considerada um "gênero menor", que acontece na fronteira da literatura e da ficção, escrita em estilo "ao rés-do-chão" (Candido, 1993, p 23-9), intimista, impressionista, familiar, quase coloquial. Como bem sintetizou John Gledson (2006, p.14), a crônica

[...] fica nas fronteiras da literatura propriamente dita; e sente-se [...] algo das tensões e das limitações que a cercam, sobretudo numa certa tendência a fazer com que ela seja o mais respeitável e séria possível. Fica perto de gêneros mais prestigiosos (conto, poema etc.), e quer libertar-se, ao que parece, das suas suspeitas origens jornalísticas e tornar-se algo mais que "essa publicação efêmera que se compra num dia e no dia seguinte é usada para embrulhar um par de sapatos ou forrar o chão da cozinha, nas palavras de Antonio Candido”.

Pensando no que foi dito sobre a crônica por esses dois respeitáveis estudiosos da literatura brasileira, procuramos continuar a desenvolver a discussão sobre essa forma textual, com base em uma outra perspectiva, a das "transferências culturais" (Espagne, 1999), e em relação a um outro tipo de texto também publicado no espaço dos rodapés dos jornais, ofeuilleton-varietés (folhetim-variedades).

Nossa primeira constatação é bastante simples, mas, ao mesmo tempo, complicada de explicar: aquilo que definimos como "folhetim-variedades" no Brasil parece-nos ter sido uma rubrica jornalística mais ampla que as "variedades" / varietés" francesas. Ou seja, é necessário que compreendamos os processos de modificação pelos quais passaram as rubricas nos jornais brasileiros mais importantes da época. Essa última questão, necessariamente, coloca em evidência 
uma outra: a da elasticidade das formas literárias que foram criadas no e para o espaço da imprensa periódica em geral, no XIX. De acordo com Marie-Eve Thérenty e Alan Vaillant (2001, p.10), “a importância do jornal para a literatura está ligada a [...] três características essenciais: o jornal é periódico, midiático e coletivo". ${ }^{1}$ Como já mencionado, a elasticidade na forma dos textos está amplamente vinculada a essa ideia dos dois críticos franceses e a, pelo menos, três critérios de extensão e adaptação: tempo (histórico e cronológico), espaço interior do jornal - no qual as rubricas estão em constante troca e integração - e espaço externo do jornal - onde acontecem os jogos de interação entre as rubricas e o espaço público. ${ }^{2}$ Neste texto, pensaremos principalmente em termos desses dois últimos pontos.

\section{A aurora da imprensa cotidiana no Brasil}

Em relação à imprensa brasileira do século XIX em geral, relembramos aqui, rapidamente, alguns fatos. ${ }^{3}$ Ainda que tenham vigorado a proibição total da imprensa/impressão e a censura à circulação de edições durante todo o período colonial, é fundamental constatar que a instalação da imprensa quotidiana no Brasil, depois da transferência da família real e da corte portuguesa para sua ex-colônia, não aconteceu em meio a um vazio cultural completo. Podemos

1 "l'importance du journal pour la littérature tient [...] à ses trois caractéristiques essentielles: le journal est périodique, médiatique et collectif.»

2 Tomamos aqui a definição de Jürgen Habermas (2008, p.29), para quem o espaço público designa principalmente a "sphère des personnes privées rassemblées en un public". Ele nasce de um público de leitores para quem, graças a seus novos hábitos de leitura e recepção das novas publicações, cria-se uma rede de comunicação pública baseada no uso da razão e do julgamento, no seio da esfera privada. A esfera pública burguesa e a opinião pública compreendem então um círculo privado de pessoas, o qual "en tant que public, entretiennent des relations entre elles et promeuvent des échanges au sein de cette même sphère" (ibidem, p.39).

3 Para mais informações sobre o assunto, ver Sodré (1967) e Martins \& Luca (2008). 
citar como exemplo os padres jesuítas, os quais formaram ateliês de impressão em suas missões, textos de natureza política para circular ideias, entre outros fatores. ${ }^{4}$

Um dos principais jornais da aurora da imprensa brasileira, o qual sobrevive ainda em nossos dias, foi o Jornal do Commercio, criado em janeiro de 1827 pelo ex-livreiro Pierre Plancher, um francês exilado no Brasil. O Jornal tornou-se um periódico de grande importância, além de uma espécie de voz oficial durante todo o império (18221889). Ele estava tão alinhado aos acontecimentos da imprensa francesa que traduziu e publicou, a partir de 31 de outubro de 1838, Le capitaine Paul, de Alexandre Dumas, ou seja, apenas alguns meses depois da publicação do folhetim no jornal francês Le Siècle (Meyer, 1996, p.282). Assim, O Jornal do Commercio abrigou alguns dos grandes títulos de folhetins franceses da época, como os Mystères de Paris, no início dos anos 1840. Também ali, entre 1846-1847, o comediógrafo brasileiro Martins Pena, grande conhecedor de música e da arte da encenação, escreveu uma série exclusivamente sobre o teatro lírico, "A semana lírica". É preciso dizer que um folhetim que comportava tamanha especialização era algo singular na primeira metade do século XIX brasileiro, justamente porque as temporadas dos teatros, quaisquer que fossem, não eram suficientemente variadas para justificar a publicação de dois ou três folhetins semanais sobre os espetáculos, e nem regulares o suficiente para que o periódico pudesse contar certeiramente com uma "coluna fixa" de crítica teatral no espaço em questão. Em todo caso, as temporadas dos anos 1846-1847 ofereceram rico material para Martins Pena, e o Jornal do Commercio o absorveu. Por fim, o Jornal foi o primeiro periódico a fixar a rubrica "crônica", chamada "A semana", no rodapé da página, a partir de 1852. Para constituir essa crônica da semana, Francisco Otaviano retomava, em seus textos, o debate político do momento, como quase todos os cronistas brasileiros que, na época, o sucederam viriam a fazer. Assim, podemos arriscar a afirmação de que a "crônica” segue ainda em nossos dias o debate político, no sentido largo do

4 Para mais informações sobre o assunto, ver Morel (2008). 
termo, apesar das transformações pelas quais passou a rubrica, uma vez que quase todos os nossos escritores, desde o século XIX até os nossos dias, passaram um dia pela "escrita obrigatória da crônica", e que ela guarda em si uma espécie de "dever” em relação à política.

\section{Um jornalista sozinho não faz a primavera da imprensa}

Machado de Assis, que mudou todos os paradigmas da literatura produzida no Brasil até o século XIX, escreveu vários tipos de texto para jornais e revistas entre 1859 e 1897 . Ele criou, e publicou-a quase toda na imprensa, uma nova prosa de ficção, que fez, a partir de 1880, uma verdadeira revolução na literatura brasileira e em sua relação com a "importação" de modelos europeus, principalmente franceses, como começamos a demonstrar. ${ }^{5}$ Esse escritor é evocado neste texto porque ele começou a colaborar para os jornais quando era ainda muito jovem e continuou a fazê-lo durante os quase cinquenta anos que se seguiram, entre 1859 e 1897. Ele seria, assim, uma espécie de escritor-jornalista por excelência no século XIX. Pensando na questão da autorrepresentação do "gênero" crônica, observaremos a seguir como o escritor-jornalista se refere aos seus textos no espaço desses seus escritos. Citamos a seguir um texto, a respeito do folhetim/folhetinista, que a esta altura já é bastante conhecido, mas do qual podemos ainda extrair algumas informações:

O folhetim, disse eu em outra parte, e debaixo de outro pseudônimo, o folhetim nasceu do jornal, o folhetinista por conseqüência do jornalista. Esta íntima afinidade é que desenha as saliências fisionômicas na moderna criação.

O folhetinista é a fusão admirável do útil e do fútil, o parto curioso e singular do sério, consorciado com o frívolo. Estes dois elementos,

5 Pedimos licença para mencionar aqui o primeiro artigo que escrevemos sobre o assunto: Granja (2009). 
arredados como pólos, heterogêneos como água e fogo, casam-se perfeitamente na organização do novo animal.

Efeito estranho é este, assim produzido pela afinidade assinalada entre o jornalista e folhetinista. Daquele cai sobre este a luz séria e vigorosa, a reflexão calma, a observação profunda. Pelo que toca ao devaneio, à leviandade, está tudo encarnado no folhetinista mesmo; o capital próprio.

O folhetinista, na sociedade, ocupa o lugar do colibri na esfera vegetal; salta, esvoaça, brinca, tremula, paira e espaneja-se sobre todos os caules suculentos, sobre todas as seivas vigorosas. Todo o mundo lhe pertence, até mesmo a política [...]. (Machado de Assis, "O folhetinista", O Espelho, 30.10.1859) ${ }^{6}$

Essas "Aquarelas" que Machado de Assis escrevia para a revista $O$ Espelho assemelhavam-se a alguns dos portraits publicados pela imprensa francesa, quadros que representavam as "espécies" da sociedade (o comensal, o funcionário público aposentado, o folhetinista etc.), todos pintados com tintas fortes. Ou, ainda, nas palavras de João Roberto Faria, nesses textos, "Machado é o observador da vida social que busca apresentar as características de certos tipos que deslustram a sociedade em que vivem" (Assis, 2009, p.13).

No trecho citado, descreve-se o folhetinista como uma declinação do jornalista e, em consequência, do jornal. Com base na definição dessa nova "costela de Adão", faz-se uma distinção entre jornalista e folhetinista, como se o primeiro não tivesse intersecção com o segundo, e, no limite, isso também não se passasse no sentido inverso: o jornalista é descrito como uma figura séria, que reflete, observa e evoca a densidade analítica; ao mesmo tempo, do folhetinista, um "animal da sociedade", mais popular do que aquele que lhe deu origem, põe-se em evidência sua natureza leviana e contraditória.

6 Existe uma boa e recente edição dos textos em prosa que Machado de Assis escreveu para $O$ Espelho, organizada por João Roberto Faria e publicada pela Editora da Unicamp em 2009. Há ainda uma edição fac-similada da revista $O$ Espelho, publicada pela Biblioteca Nacional em 2008. 
Ele se comporta como um colibri agitado, que suga todas as seivas, mesmo aquela da política, de onde "o parto curioso e singular do sério, consorciado com o frívolo".

Como já observamos, no Brasil, a política constituiu-se desde Francisco Otaviano como um dos assuntos mais presentes e importantes do "folhetim-variedades". Dessa forma, o folhetinista nos remete à crônica, à forma como a rubrica se constituiu na França, onde ela apresenta características algo distintas daquelas que se desenvolveram aos poucos no Brasil, sobretudo em relação à forma como a política ali se apresentava e era discutida, à pouca intromissão do narrador e a respeito do "contrato ficcional" da crônica, que exclui a invenção. De acordo com Thérenty \& Vaillant (2001, p.68-9), em 1836, "o ano I da era midiática", a crônica apresenta-se como uma lista heteróclita de acontecimentos e guarda um respeito total ao contrato referencial; ela faz um repertório dos fatos da véspera e segue uma hierarquia de assuntos. No caso da política, a hierarquia era nobiliária, o dia do rei, da família real, da corte e, só então, o da cidade. Por fim, os comentários dos cronistas d'além-mar descolamse pouco da notícia e não são digressivos. Se a política estava tão presente no texto francês, ainda que a crônica fosse mista entre esse domínio da vida pública e as variedades, isso quer dizer que, no Brasil, nem a divisão entre jornalista e folhetinista que estrutura o texto machadiano se justifica bem, nem a restrição "até mesmo à política”. Observa-se ainda que, em relação ao jornalismo francês, a censura à imprensa brasileira durante o segundo império não foi tão grande, nem teve regras muito definidas. $O$ folhetinista fala de tudo, da forma como ele escolhe fazê-lo, sem esperar uma punição certa. Ensaiando uma conclusão parcial, podemos imaginar que uma das consequências da restrição "até mesmo a política" seria enfatizar ironicamente a gravidade excessiva do assunto do folhetim. Se essa compreensão do texto machadiano estiver correta, estamos aqui diante de uma nova proposta para o folhetim-variedades no Brasil, em relação à "matriz" (crônica) francesa. A política, que faz parte do mundo das coisas sérias e graves, passa a ser apenas uma das seivas experimentadas pelo folhetinista, e ambos, folhetim e política no 
folhetim, precisam amaneirar-se. É difícil imaginar que a crônica política da Revue des Deux Mondes, por exemplo, tivesse podido constituir-se dessa mesma maneira. Ao sul do Equador, foi preciso refletir diferentemente a respeito da natureza do espaço do rodapé e da rubrica chronique, e ali se foi criando, a nosso modo, a "crônica de variedades".

Na França, como argumenta Marie-Eve Thérenty (2007, p.82), a rubrica da maior parte dos jornais, longe de ser

[...] uma estrutura que engessa a atualidade, permite, ao contrário, um conhecimento do mundo de uma maneira leve. Trata-se de um sistema bem flexível que permite e justifica a circulação de textos e que, de certa forma, existe para ser rompido em resposta à atualidade (tradução nossa $)^{7}$

No Brasil, esse sistema flexível parece ter sido, no que tange às rubricas, ainda menos rígido que na França, onde, como lemos na citação, o sistema já permitia grandes trocas. Em consequência, a circulação entre os textos de cada um dos periódicos tornava-se ainda mais fácil, uma vez que, justamente, relacionando-se a sociabilidades menos variadas que na Europa, ${ }^{8}$ os jornais tinham uma escrita mais restrita. ${ }^{9}$

7 "une structure qui fige l'actuallité, permet au contraire de rendre compte du monde avec souplesse. Il s'agit d'un système très flexible qui permet et justifie la circulation des textes et qui n'existe en quelque sorte que pour être mieux brisé en réponse à l'actualité [...].»

8 A ideia de que as sociabilidades seriam menos variadas no Brasil toma como referência a definição de "mondaneidade da imprensa", desenvolvida por Guillaume Pinson (2009). O autor demonstra que existe uma relação possível entre cultura midiática (que nos conduz à ideia de amplas mediações anônimas) e sociabilidade (que tomamos como forma concreta de trocas sociais entre os indivíduos).

9 Referimo-nos aqui a uma ideia que se tornou clara para nós a partir do estudo da obra cronística de Machado de Assis, mas que Marie-Eve Thérenty (2007, p.78) também já havia generalizado para os jornais franceses do XIX: “Le journal invente $[. .$.$] un système complexe [...] d'ordonnancemment du monde avec une$ typologie qui porte autant sur le monde que sur l'écriture qui dit le monde". 
Dessa forma, no Brasil, teria havido uma "contaminação" das "variedades" pelo espaço do "alto da página" (onde estavam as notícias), além de o comentário sobre a política ter se tornado mais leve pelo trabalho do folhetinista. Mas, continuando a pensar no processo de transferência do folhetim nos jornais, teríamos tido também uma "contaminação" entre as rubricas "crônicas" e "variedades", como pretendemos ainda demonstrar neste texto.

Tomando Machado de Assis como um modelo geral de nossos escritores-jornalistas de meados do século XIX, conforme analisamos em sua obra de cronista/folhetinista, o espaço semanal do rodapé da página assinado, contrariamente à crônica francesa, carregou-se de elaboração literária, e ali observamos uma utilização livre da retórica, da ironia, das citações da tradição literária e cultural, da paródia, da inserção de pequenos intervalos de ficção entre os comentários, da autorreferenciação, entre outros. Como exemplos, apresentaremos a seguir duas pequenas reflexões do narrador-cronista machadiano, ambas de natureza similar a outras tantas que aparecem frequentemente nesses folhetins-variedades.

Primeiramente, o narrador-cronista nos fala com muita ironia de um "milagre". O senhor deputado Lopes Neto fizera na Assembleia Nacional, diante de uma plateia de 500 pessoas, uma espécie de defesa da presença francesa no México e do golpe que levara ao poder, em 1863, o imperador Ferdinand Maximilien. O narrador sinaliza: «E desde já declaro que o tom de gracejo com que me exprimo resulta da natureza do folhetim e da natureza do milagre [...]» (Machado de Assis, "Ao acaso", Diário do Rio de Janeiro, 20.6.1864).

Nesse texto, faz-se, na realidade, uma associação entre o tom da prosa adotado no folhetim-variedades/crônica (uma das características da "natureza" do folhetim) e o olhar do narrador-cronista sobre a vida política quotidiana carioca. Essa ironia fica explicitada pela palavra "milagre", usada para definir o discurso desastroso do deputado diante de centenas de ouvintes.

Em seguida, lemos um trecho em que o narrador-cronista nos diz, em seu texto de variedades, que a sua boa organização seria a seguinte: 
Devia começar hoje por uma lauda fúnebre. Inverti a ordem e guardei-a para o fim. O que me embaraçava sobretudo era a transição do triste para o ameno [...] no folhetim é um erro entristecer os leitores para depois falar-lhes em assuntos amenos ou festivos. (Machado de Assis, "Ao Acaso", Diário do Rio de Janeiro, 17.7.1864)

Lembrando a crônica-política francesa, onde havia uma hierarquia convencional dos assuntos, existe, nessa reflexão sobre a ordem dos comentários do narrador-cronista, um olhar arbitrário que nos propõe reflexões no que concerne à autorrepresentação. Por que seria um erro entristecer primeiramente os leitores para em seguida lhes falar sobre amenidades? Podemos pensar em duas hipóteses para continuar esse raciocínio: ou o folhetinista está se referindo, no caso dos "erros" e "acertos" na ordem dos assuntos, primordialmente, ao entretenimento do leitor (e nesse caso ele guardaria a notícia triste para o fim, quando poderia falar meio atropeladamente do assunto, em função do número de caracteres que se esgotava em seu texto de tamanho predeterminado); ou estamos diante de um narrador que se autorrepresenta claramente como organizador do discurso, o que, nesse caso, nos mostra que a ordem dos assuntos importa pouco, desde que ele esconda com a manobra retórica do comentário autorremissivo, aquilo que lhe causa uma real dificuldade: a transição entre dois assuntos díspares. Aqui uma pequena digressão: sempreé bom lembrar que o segundo caminho é o que nos conduzirá à prosa machadiana de alguns anos mais tarde.

Acrescentamos a esta análise um segundo exemplo do "caso" brasileiro. Acreditamos que Machado de Assis tenha sido o nosso primeiro escritor-jornalista a exprimir-se diretamente a respeito da mistura entre política e variedades no rodapé dos jornais, mas, antes disso, ele foi precedido por outros folhetinistas, entre eles José de Alencar, esse escritor tão importante para a literatura brasileira, que experimentou a fórmula do romance-folhetim no rodapé da folha política com sucesso (Cinco minutos, A viuvinha e O Guarani) e escreveu folhetins-variedades, mas que, ao contrário de Machado, continuou a desenvolver sua obra literária longe dos periódicos, a partir dos anos 
1860. Também citando outro texto bastante conhecido de Alencar, veremos que o escritor já compreendera muito bem que faria uma grande diferença desenvolver a parte literária desse "bicho de sete cabeças", o folhetim-variedades ou a crônica:

Entretanto a mim não me sucedeu o mesmo. Tinha-me divertido, é verdade; mas aquele domingo cheio, que estreava a semana de uma maneira tão brilhante, fazia-me pressentir uma tal fecundidade de acontecimentos, que me inquietava seriamente. Já via surgir de repente uma série interminável de bailes e saraus, um catálogo enorme de revoluções e uma cópia de notícias capaz de produzir dois suplementos de qualquer jornal no mesmo dia. E eu, metido no meio de tudo isto, com uma pena, uma pouca de tinta e uma folha de papel, essa tripeça do gênero feminino, com a qual trabalham alguns escritores modernos, à moda do sapateiro remendão dos tempos de outrora.

É uma felicidade que não me tenha ainda dado ao trabalho de saber quem foi o inventor deste monstro de Horácio, deste novo Proteu, que chamam - folhetim; senão aproveitaria alguns momentos em que estivesse de candeias às avessas, e escrever-lhe-ia uma biografia, que, com as anotações de certos críticos que eu conheço, havia de fazer o tal sujeito ter um inferno no purgatório onde necessariamente deve estar o inventor de tão desastrada idéia.

Obrigar um homem a percorrer todos os acontecimentos, a passar do gracejo ao assunto sério, do riso e do prazer às misérias e às chagas da sociedade; e isto com a mesma graça e a mesma nonchalance com que uma senhora volta às páginas douradas do seu álbum, com toda a finura e delicadeza com que uma mocinha loureira dá sota e basto a três dúzias de adoradores! Fazerem do escritor uma espécie de colibri a esvoaçar em ziguezague, e a sugar, como o mel das flores, a graça, o sal e o espírito que deve necessariamente descobrir no fato o mais comezinho!

Ainda isto não é tudo. Depois que o mísero folhetinista por força de vontade conseguiu atingir a este último esforço da volubilidade, quando à custa de magia e de encanto fez que a pena se lembrasse 
dos tempos em que voava, deixa finalmente o pensamento lançar-se sobre o papel, livre como o espaço. Cuida que é uma borboleta que quebrou a crisálida para ostentar o brilho fascinador de suas cores; mas engana-se: é apenas uma formiga que criou asas para perder-se.

De um lado um crítico, aliás de boa-fé, é de opinião que o folhetinista inventou em vez de contar, o que por conseguinte excedeu os limites da crônica. Outro afirma que plagiou, e prova imediatamente que tal autor, se não disse a mesma coisa, teve intenção de dizer, porque, enfim nihil sub sole novum. Se se trata de coisa séria, a amável leitora amarrota o jornal, e atira-o de lado com um momozinho displicente a que é impossível resistir. (José de Alencar, publicado originalmente em "Ao correr da pena", no Correio Mercantil, 24.9.1854). ${ }^{10}$

Pedimos desculpas ao leitor pela longa citação, mas a riqueza de informações que ela traz nos era necessária. Vemos que estamos diante de um "Homem de Letras" do século XIX, que tem a missão de redigir um novo texto para um jornal, "inaugurando práticas de publicação novas” (Thérenty, 2007, p.16). Mais uma vez, observamos a utilização da metalinguuagem no folhetim, onde o colibri folhetinista faz o seu "pensamento lançar-se sobre o papel, livre como o espaço”. Livre é o pensamento, livre é o espaço que o papel ocupará, o que nos remete à ideia de que a "natureza" do folhetim está em constante construção. Já a monstruosidade do folhetim, "esse novo Proteu”, no texto de José de Alencar, está ligada à diversidade de assuntos que o escritor deve abordar em sua "revista da semana", assim como à forma de transição entre eles e à natureza do assunto (do entretenimento ao sério, dos prazeres às misérias sociais). Nesse trecho, tanto a passagem entre assuntos, quanto os assuntos em si, são problemas do folhetim: "os bailes, as festas, um catálogo enorme de revoluções e uma cópia de notícias capaz de produzir dois suplementos de qualquer jornal no mesmo dia". No entanto, aquilo que

10 Existe uma excelente edição desses textos de Alencar, preparada e publicada em 2004 por João Roberto Faria (cf. Alencar, 2004). 
preocupa o folhetinista em 1854 é a variedade, e não a natureza de um assunto em específico, a política, por exemplo. Para ele, bailes, noites de festas e revoluções ocorridas na semana estão em equilíbrio como assuntos da crônica de variedades, assim como o estão as observações do escritor, o qual faz, ainda, da expressão de seus próprios pensamentos e julgamentos, o conteúdo de seu escrito. Voltando à metáfora de Proteu, o folhetim, que é nomeado indiferentemente também de "crônica" no trecho apresentado, exige do escritor a invenção de seu texto e, ao mesmo tempo, a invenção da rubrica em que o escrito deve caber, assim como de seu gênero e tom. A medida do talento do escritor-jornalista quem dá é o público, representado aqui pela imagem da leitora que amarrota, enfadada, o jornal, em oposição (imaginária a partir da crônica) àquela que estará interessada no escrito. Portanto, uma terceira dificuldade apresentada pelo "novo Proteu" assentar-se-ia na preocupação com o público leitor que consumia os textos da imprensa e a quem era preciso "agradar". Alencar fala do espaço do folhetim como um espaço de entretenimento obrigatório e seu objetivo seria o de construir um texto interessante e divertido, mas com os meios que ele sempre tivera (pena, papel e tinta, tríade que ele associa ao gênero feminino), tudo isso à moda do "sapateiro remendão”. A menção desse ofício remete o processo de escrita da crônica a uma espécie de improvisação, de bricolagem, de artesanato pouco refinado, o que nos conduz, mais uma vez, à ideia de um texto em construção. Fica claro que o escritor-jornalista tem uma tarefa pesada, e a evocação do "sapateiro remendão de outrora" nos remete, por oposição, até mesmo à ideia da littérature industrielle de Sainte-Beuve, desenvolvida no seu texto bastante conhecido e citado de $1^{\circ}$ de setembro de 1839, publicado na Revue des Deux Mondes. Quarta ideia importante: Alencar nos apresenta uma associação da imagem do folhetinista a de animais. Primeiramente, um animal gracioso, rápido e inventivo, mas, logo, se passa à degradação dessa associação à medida que, de pássaro, o narrador-cronista passa a falar de insetos, e, nesse gênero, de borboleta (que é a imagem que o folhetinista tem de si) chega à formiga com asas (que seria a imagem real do que é esse escritor). 
Essas comparações nos enviam longe, ao primeiro folhetim de La Presse, escrito em $1^{\circ}$ de julho de 1836, no qual Frédéric Soulié compara o folhetim - e não o folhetinista - a uma borboleta. Depois dos dois primeiros parágrafos, a respeito do que se teria passado caso o folhetim existisse desde a Antiguidade, ele nos diz:

Mas foi-se o tempo dessas belas transfigurações alegóricas: e se eu precisasse representar o Folhetim de uma maneira palpável, o que eu ousaria propor aos meus leitores, seria fazer a figuração do Folhetim [sic] como uma grande borboleta. Às costas de uma pena que simula o seu corpo, prendei, à guisa de asas, duas longas tiras de papel que os senhores leem e eis que encontramos assim nossa borboleta. (Frédéric Soulier, La Presse, 1.7.1836, tradução nossa) ${ }^{11}$

A imagem de uma borboleta composta pela pena que escreve o folhetim, à qual se colam duas tiras de papel que são o próprio folhetim, ou uma pena voadora que opera uma "varredura" dos fatos da semana, não é exatamente a mesma do animal que sobrevoa todos os assuntos de uma semana, a fim de "sugar seivas" para escrever seu texto. De toda forma, podemos pensar que as duas borboletas (metáfora que o folhetinista brasileiro exagera ao se representar como um colibri e diminui ao se referenciar como uma formiga com asas) recolhem e definem em seus sobrevoos, cada qual a seu modo, os assuntos que compõem a escrita do rodapé da página dos jornais. Em termos de figuração do folhetim/folhetinsita, provavelmente, o que se tenha passado foi que, a partir de $1^{\circ}$ de julho de 1836 , primeiro dia de publicação do folhetim de La Presse, as imagens do criador e de sua criação ligadas à metáfora da borboleta se tenham reproduzido até "pousar no caule" do folhetim sul-americano quase vinte anos

11 "Mais le temps est passé de ces belles transfigurations allégoriques: et s'il me fallait réprésenter le Feuilleton sous une forme palpable, tout ce que j'oserais me permettre de proposer à mes lecteurs, ce serait de se figurer le Feuilleton sous l'aspect d'un vaste papillon. Au dos d'une plume qui simule le corps, attachez, en guise d'ailes, les deux longues bandes de papier que vous lisez, et voilà notre papillon tout trouvé.» 
mais tarde. No Brasil, a partir de Alencar, e como podemos ver pelo texto de Machado, a imagem repetia-se em 1854 e 1859.

Essas metáforas podem servir de exemplo, quando se pensa na definição do "gênero" crônica, para a tensão entre a narrativa e a invenção como natureza e limite da prosa do folhetim: quanto mais o folhetinista inventa/borboleteia e se afrouxa o compromisso com a referencialidade, mais ultrapassa as fronteiras da crônica, que eram, na versão francesa, próximas ao "relato"; o folhetim-variedades brasileiro tomava o itinerário da invenção. Esse segundo caminho, escolheram-no, ao que tudo indica, Alencar, Machado e praticamente todos os nossos outros escritores-cronistas.

\section{Rubricas daqui e de além-mar}

Nos jornais do século XIX francês, como vimos, ao menos até a aparição do Petit Journal, de Moïse Millaud (1863), a crônica desenvolveu-se como um artigo que apresentava a seus leitores um relato, na maioria das vezes, ligado à política, em que os assuntos eram dados de forma hierárquica e o narrador assumia uma postura pouco intrusiva.

Pensaremos, a partir de agora, na relação entre crônica e romancefolhetim. Como já mencionamos, o Jornal do Commercio funcionou como uma espécie de "diário oficial" durante uma boa parte do período imperial brasileiro. Assim, ele recebia dinheiro do império, o que quer dizer que não sobrevivia apenas de assinaturas. Havia forçosamente uma priorização do noticiário político e comercial, e o folhetim seguia, antes de tudo, esse ritmo.

Publicando os romances-folhetins franceses em tradução, o Jornal adotou, portanto, uma dinâmica própria de utilização do rodapé, e a ideia que apresentamos agora é a de que essa utilização espacial da página (pela qual escolhemos começar nossa análise, em vista da subvenção mencionada e duração do Jornal) tem também muito a dizer sobre as características textuais que a crônica acabou assumindo por aqui. 
No jornal francês, os romances-folhetim ocupavam, em geral, dois bas de page/rodapé; aqui no Brasil, o aumento e a diminuição do número de linhas dos rodapés ${ }^{12}$ ou a publicação dos capítulos do romance em apenas um rodapé apontam para modificações nos cortes da narrativa e, consequentemente, nos efeitos previstos para a leitura. Ainda por razões editoriais e tipográficas, ou de acordo com a quantidade de informação política e comercial que o jornal precisasse veicular, principalmente aquelas vindas da parte do governo (as transcrições dos debates das câmaras, decretos e toda sorte de papéis oficiais), espremia-se ou alargava-se o espaço reservado ao folhetim no Jornal do Commercio. Com certeza, esse "efeito elástico" incidindo sobre os romances quando de sua transferência para o jornal brasileiro operava modificações na obra literária e em sua recepção, como veremos.

Um exemplo vem justamente dessa organização muito variável do romance-folhetim. Em algumas ocasiões, aconteceu de ele se seguir ao folhetim-variedades, como acompanhamos pela Figura 1.

12 Sobre a distribuição dos capítulos do romance-folhetim no espaço disponível para eles, gostaríamos de observar que a variação de tamanho nos diferentes dias é imensa. No que tange à distribuição dos capítulos, em geral, ele se assemelha à forma como procedem os jornais franceses: ou se publica um capítulo que corresponde a dois rodapés, ou dois capítulos que correspondem a dois rodapés ou, ainda, um capítulo mais longo distribuído num só folhetim. Chama a atenção, como dissemos, a oscilação na altura desse espaço do rodapé. Nesses dias de publicação de um capítulo e um folhetim (também às vezes quando o folhetim ocupa duas páginas), observamos uma incrível variação de quantidade de texto. Por exemplo, na publicação de O buraco do Inferno e Deus Dispõe, em 1851, temos: o rodapé distribuía-se por seis colunas, seguindo o arranjo tipográfico do "alto de página"; cada linha de cada coluna comporta cerca de 39 caracteres. Nos dias 14 e 15 de outubro, a altura é de 45 linhas; já no dia 16 de outubro, temos 31 linhas. Para termos ideia da variação, contamos:

- 45 linhas x 39 caracteres comespaços = 1.755 caracteres comespaço, ou cerca de 30 linhas digitadas nos moldes de hoje, em tipo 12, por coluna.

- 31 linhas $\times 39$ caracteres comespaços = 1.209 caracteres comespaço, ou cerca de 20 linhas digitadas nos moldes de hoje, em tipo 12, por coluna.

Aparentemente, embora haja variações em relação à quantidade de texto do romance-folhetim nos jornais franceses, elas não são consideráveis, pelo contrário. 


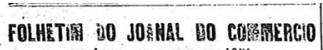
DO 10 DE NOTEYBRO DE 1851

Colh tim está nimiamento agradecido aos $\mathrm{S}$ rs. directores do theatro lyrico; os seus desibteressados conselhos forăo attendidos; subsiituic os consslheiros ofliciazs, e a direztoria não terá porcerto tido occasiäo de arrepender-se por the haver dado a pri.ferencia.

Por amor do publico, do theatro e dos artistas, aigda uma vez lt'o agradecemos: é iuf-lizment: tão commum a reluctancis da má vonta ze contra a admoestą̧õas mis ou meaos severaz, potéa seimpre justrs, da amizade, que ainda quando da docilidado resulta p oreito immediato e s?nsivel, não se pó e deixar de agradecer-lhe e ce applaudi-la.

Foi supprimida a claque; nethum caralheiro do lustre appareceu.... E 'qual fol o resultado? Desile que o rerdadsiro publico reconleceu quee tava a sós, que não so havia reandado ao theatro quem o substituizse, e sèm proeuração sua fosse distribuiado palmas e bravos, desde que o pullico rec uhecen que o theatro the havia restituiţo toda a sua liberdado do opslaudir aquiils que the parecease merocer applouso, desappareceu a frieza que a principio reinava, e o publico applaudión e os artistas, que sa-

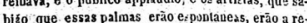
bí́o que essas palmas erão eipontancas, erão a retribuição do seu merecimento, e nãu os resultadas de uma cabsals para favorecer interesses allelos, hadẹmonstraçes

Se nầ bouve carallheiros do lastre, se não houve Willotes dalos, en cosapersasă

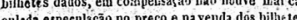

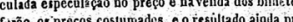
rou á commissão directora que teve razão do no

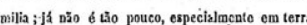
tào falta de piroação, e, bagundo os apantamen'e estadisticos do Sr. Hadlok Lobo, tão precisada de impartsę̃o feminin.

Quaato a es ectacule Iyrico, tudo ceminha bem: j! não eı a pouco interessante espectaculo essa salx cheia ds espectadores, essę camarotes animados, c todes na espectativa : póde-se dizer quo ess foi a vordadeira recita de eätrês da companthia.

0 Sr. Liblocesta tiva a vantagem do quebrar 0 cncautameuto que tolhia os applausos; cuviato-0, e vendo que não partiảo as palauss de eneoinzien "2, 0 pubiico tentig que fadia sem comprometter-se ap$p^{\prime} 2 n d i b$ : cumpre dizer que elle o merecia ; merecen-0 especialnente na sua famosa aria fual, que brizou os espectadores a chama lo a scena par victoria-lo.

Animac̀a pslo de:ejo le ag a a.drr, a Sigenora Zacchini mystrou algum prozterso, o esperamos que cstudo - se esmere para torna 10 a jida mals sensivel. 0 pu bice faminene facilmente to apairona pelas itues pro primes douas, o tanio quo,

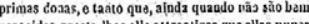
pereeidas, presta thes ello sttractivos que ellas nunaca pošuirão. As Hltes, as Meré2s, as Condianis, até recebêtâo louvores de formosas, de eccautadoras, contra oz quans protestavב̃o os seus espeltios. Estude. esinere-se a Signoia Zsechíai; continuo, o tal ô o poder da voz feminina, que, adquirida a by apathia yubtics, wado the reconhesers de bom, do louvavel,

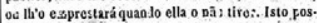
io, aconselhamos-lho quo melhor attenta ar por menores do seu dueto com-o tenor, por exemplo n quella p2ssagem do zligro: spargl unx cmara logrime su questo pegno cllor.

em que o sograbo toma a parte Inferior ao tenor. E uma falia de memoria que em tojas as represen ouvir. 0 thostro esteve cheiv; nem um camarotc, Seus cartillos, mais ou menos primissimos? Essas pu- I

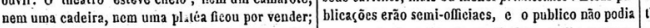
o gauderismo desappareceu, o a caixa do theatro dirá crer que se fizesse tanto eșallhafato, se lhe combiu- $C$ quanto com isso se lucrau.

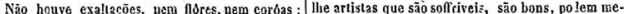

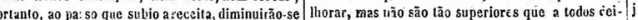
portunto, ao pa:so que stebio areccíta, diminuirão-se as de:p:zai do theatro; e além da economia evitouse es:e ridiculs que ia matando a commissão directora, e preparando-lhe tantas insaleul sveis difliculdades.

Emfim, tudo concorreu para qus of follhetion so fanasso do sen tritumgho; at á anesmo o ballo cueto lo $3^{\circ}$ acto, entre o baryiono e o tenor, que a princiio havião supprimido, fui restaurado, e carita:o.... go diremes cam?

Depois que appareceu of Folhetim, já não se apregoảo $\mathrm{ccm}$ tinta bulha e matinada as divinas, sublimes; já nesm, se re:ua, e se argevera que rúca se havia dito que erão de prinissimo cartello os artislas da njya com jảjịia ; já não so mostra toda esia erudição de eacommenda ácerea de theatro - de artistas, e livre dessa co:cção o publico reconheceu que podia contentar-se com os artistas cantantes da zova companhia, que tinhžo elles merecimesto real, que a! guma cousa aín క̧a podiāo a a tquiir ; que nois podia elle publico esperar, não mara vilhas, não seraphius, tão primissimi cartelli, eå nom ecquer papulo, para os arrancar da lialia, Irazê-los zo Rieda Janeiro; m2s, finslueute, artista que the a:segurassem al zumas doces emcções, al gumas lioras do distracção e de recreio.

Se esse resoltado logo nos primeiros dias não appareccu, de quem é a culpa? Para que nos fizerão chegar agua á boca con tantos fallatorios; para que nos mettérào pelos bastidores de todos os theatros euro peos, o nos contario

2ções temns notado, o que por certo contamos não a ler Klopstack atè ao anoitecer : de ordibario, gosto notár mais.

$0 \mathrm{Sr}$. di Lauro.... esperemos que para a uova representação terá elle tido tempo do estudar aqueoll psssagem em sami-colchess ascendentes, do seu dueto de des.fio com o tenor. Essa pass?gèm é essencial, pois exprime perfoitemente a idéa do autor; per is:o deve 0 artista, interprete de lla , traduzi-la com gdelidade.

Aiada lae observaremos, o tamban ao $\mathrm{Sr}$. Latocceta, que nasse đueto não seriá mal cabida alsum animação, mais alşum calor.

Nasse dueto es sentimentos do odio e da vingan ca sobem á maior exaltação ; ob de mister que os etntores o siatão o o fação sentír.

Muito estlmariamos tambem que não so supprimitse o pitu allegro do ducto, que coin elle nos pare ce acoliatia mais agra arelmente.

Em resuino e concluindo, essa repretentaço foi em todo o sentido superior is precedentes, e dá es. perauças de outras ainda melhores.

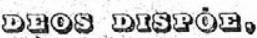

POR ALEXANDRE DUSLAS. (')

$$
\text { SULAEก E ихт. }
$$

- Querido pai, disse Julio, depois de ter abraça to o barâ), tegan lo me dizem, ha muitas luoas que estais á minha osptra, ten lo se debal le procurado-mo na floresta, onde me-Dão-puderẵ echar pela sinples razão do eu ali nĩo estar Sabíndo, como costumo, com uma espiogarda no hombro e um livro na slgibeira, foi sömente ds ultimo que me servi. A uma millia diqui, sentel-me na rolva, o puz-me (*) Yido Jormal do Conmercio a. 300. mais de ler do qua de cscar. Mas tiphe

- Al! sim, Jallo.

- Ah! sim, Jullo.
- E o que vem a ser? Pareceis-me preoccupado e triste.

0 barào ollhou para Christina, e pareceu hesitar. . - S) minha presença ros incommoda, disso Cbristina, eu immediatamente me retiro.

- Não, minha Alha, Aca. Tens firmeza e resoluçัo, nẵo é assim?

calo detteis me medo, disss Chritina. Oh! estou com presontinento de alguma desgraça.

- 1.' preciso que saibas, proseguio o barão, o que me trouxe aqui ; visto que conto comtigo para decidires Julio a fzzer o que the eu venho pedir.

- Que quereis, pois, que eu frģa? perguntou Julio.

barão, dan lo-llte uma carts, diste :

- Lé a alto.

- E uma carta de meu tio Frílz.

E leu, sendo mais de uma vez faterrompido pela sua emoçio, a seguiots crirta:

- Nova-Yotk, 25 do agosto do 1811.

- Meu prezadissimo irmăo,

- E um moribundo quem to escreve. Alacado de uma enformidado de que se nh̃o escapa, nảo sabicel do leilo em que estou jazendo do dous meres a ain'a tres mezes de visa. Meu medico, que.6 um amiso meu, coltrecendo a teop pra de meu caracter, - cedendo a minhas jastancias z disso-me a verbade.

- Tu tambem mo conhecos, ollam tahes quo so esta noticia me foi dolorosa o sensirel, nio col por um posilanime tertor al morte, perm pelo pezar de esta parte senão para a cova, Resta-me, contado

Figura 1 - Jornal do Commercio, $1^{\circ}$ de novembro de 1851, p.1, rodapé. 
Verdade é que isso não ocorre com frequência, mas pode acontecer, o que já nos demonstra que o espaço que cabia a cada tipo de folhetim não era rigidamente especificado, pelo menos nos anos 1840 e 1850. Assim, se o folhetim-variedades tivesse bastante assunto, ocuparia toda uma edição do jornal, mas, quando os comentários sobre as variedades eram menos extensos, "emendavam-se" dois tipos diferentes de folhetins, como em $1^{\circ}$ de novembro de 1851 e em outras ocasiões. Naquele início de novembro, isso se deu da seguinte maneira: o folhetim-variedades, muito irônico em relação ao teatro lírico, ocupou cinco colunas e meia do primeiro rodapé e "espremeu" o romance, que continuou por uma coluna e meia da primeira página e por todo o rodapé da segunda.

Nesse dia, pela primeira vez na história da publicação brasileira dos romances $O$ buraco do Inferno e Deus dispõe, de Alexandre Dumas, os quais saíam no Jornal há vários meses (e a terceira parte especificamente havia sido retomada desde 29 de setembro), quebra-se o corte original da narrativa. Publica-se, a partir da metade da penúltima coluna da primeira página, até o final do rodapé da segunda página, todo o capítulo LVII, "Esposa e mãe", e metade do capítulo LVIII, "A noite da partida”. É evidente que o segundo capítulo em questão não chegaria a ser publicado na íntegra, já que o romance precisara ceder espaço ao folhetim de crítica-teatral. Assim, o Jornal aproveita uma pausa ligeira no folhetim original, uma linha de pontos que separa duas metades do capítulo "A noite da partida" para fazer o corte. Essa interrupção, que não corresponde à original, tem efeitos importantes para a recepção. Oblitera-se, por exemplo, a sensação de suspensão e passagem do tempo, sentimentos ligados ao estado de angústia da personagem Christina nos capítulos aos quais nos referimos aqui, já que ela se havia colocado contra a partida do marido Júlio para Nova York, cidade para a qual ele iria, a fim de resolver um problema de família. No original, a primeira metade do capítulo "A noite da partida" encerra-se com a linha de pontos que se segue a um diálogo tenso entre os cônjuges. A organização tipográfica e do espaço do folhetim no Jornal do Commercio fez com 
que se distanciassem em vários dias as partes do capítulo, tendo sido aproveitado para o corte justamente a linha de pontos em questão, o que modifica um efeito importante da narrativa folhetinesca dumasiana, já que, no início da segunda parte do capítulo, Christina acorda assustadíssima durante a noite e descobre assombrada que o marido não só havia partido para Nova York enquanto ela dormia, como traíra a promessa que lhe fizera na noite precedente: deixar-se acompanhar pela esposa pelo menos durante o trecho terrestre. Ele partira à surdina, sem dizer nada. Desespero, discussão, linha de pontos. Linha de pontos, desespero e decepção. Tudo isso misturado no mesmo folhetim, sem a fórmula "continua" que adiaria a segunda parte do capítulo por quatro dias, intensifica ambas as situações do capítulo "A noite da partida", assim como os sentimentos da personagem Christina. Na publicação brasileira, esses efeitos se enfraquecem, pois o final da discussão entre Christina e Júlio - e a linha de pontos - ficam no folhetim de $1^{\circ}$ de novembro, como vimos explicando, enquanto a consciência da partida de Júlio, quando Christina acorda, só se dará dali a quatro dias, como dissemos, no folhetim de 5 de novembro.

Dessa forma, quando analisamos questões ligadas à ocupação do espaço, fica evidente que duas tipologias textuais que compartilham o mesmo rodapé podem "perturbar" a publicação uma da outra, nesse caso, principalmente, a do romance-folhetim. Certamente, o público brasileiro indignou-se menos quando Christina acordou e se deu conta da atitude covarde do marido. A presença da crônica de variedades empurra o romance-folhetim algumas colunas para frente e desorganiza (ou "modifica", se pensarmos em termos de "transferência cultural”) sua estruturação e efeitos.

Nesse caso, o Jornal não trabalhou com a medida flexível do folhetim, variando a altura dele (número de linhas), como era frequente, mas, quase contrariando as leis da física, dois corpos passaram a ocupar o mesmo espaço, sem que pudessem realmente compartilhá-lo, a não ser que pensemos que nessa coabitação, e com o perdão da comparação prosaica, tal qual num bom casamento, ambas as partes se misturam e se guardam ao mesmo tempo. 
Disso tudo nos vem ainda uma vez a ideia de que os folhetins de crítica, variedades, romance, entre outros fundiram-se em suas características ao sul do Equador e cremos que isso tenha algo a ver com o surgimento da moderna crônica, praticada no Brasil pela maioria de nossos escritores, na qual notícia, política, análise, comentário e elaboração ficcional se fundem de uma forma peculiar.

\section{À guisa de conclusão}

Como vimos, a escrita do folhetim é autorreferencial, e os narradores refletem constantemente sobre o processo de escrita e a natureza do texto que eles inventam quotidianamente para os periódicos. Seria difícil encontrar um exemplo de um texto de variedades brasileiro no qual o narrador se posicionasse de uma forma discreta. Tudo se passa, tanto na França quanto no Brasil, de maneira similar, e, pelo lado francês, podemos extrair mais um exemplo de um folhetim de Théophile Gautier:

Nosso folhetim é bastante curto (talvez o leitor o ache longo), e teríamos necessidade de uma tríade qualquer para fabricar uma sexta coluna; seis colunas não são exageradas quando se trata de suportar essa rede transversal, espécie de viga mestra tipográfica sobre a qual pesam a política e todo o edifício do jornal. (La Presse, 18.6.1838, tradução nossa $)^{13}$

Mais do que fazer metalinguagem sobre o folhetim, Gautier nos mostra, nesse pequeno trecho, o que significa de fato o espaço do rodapé, em relação ao seu próprio veículo, o jornal, e compõe a metáfora de edificação pela qual ele representa a sustentação do segundo pelo primeiro.

13 "Notre feuilleton est bien court (le lecteur le trouve peut-être long), et nous aurions besoin d'une triade sur n'importe quoi pour fabriquer une sixième colonne; six colonnes ne sont pas de trop pour supporter ce filet transversal, espèce d'architrave typographique sur lequel pèsent la politique et tout l'édifice du journal.» 
Ainda que os fenômenos da imprensa brasileira e francesa tenham sido similares em muitos pontos, o processo de transferência das novas rubricas criadas nos jornais franceses, quando de sua realização brasileira e "existência midiática" (Thérenty, 2007), em uma sociedade em que, na maior parte das vezes, vigoravam o analfabetismo e o acesso difícil à leitura, resultou forçosamente em modificações que podemos compreender de variados pontos de vista, sociológico, literário, discursivo, como aludimos anteriormente, o que nos explicará a conjuntura que presidiu as transformações (Espagne, 1999).

Quanto à nomenclatura que define os textos, utilizamos as expressões "folhetim-variedades" e "crônica" mais ou menos como sinônimas (pelo lado brasileiro das rubricas) e, igualmente, evocamos a expressão "crônica de variedades". Os textos que denominamos "crônica" no Brasil, praticados ainda por quase todos os nossos escritores, nasceram de uma fusão dos diversos tipos de textos que ocupavam o espaço do rodapé nos jornais brasileiros, crônica política, folhetim-variedades, folhetim crítica de espetáculos e romancefolhetim. Em nossa crônica, cabiam misturados a política e assuntos gerais da semana, tudo isso sob o signo da elaboração literária. $\mathrm{O}$ folhetim-variedades adaptou-se, ainda, no Brasil, a uma censura pouco intensa durante os anos do império, assim como à vida social reduzida que não comportava o grau de especialização dos folhetins franceses (sobre os teatros, a literatura, as artes, por exemplo) e os fundiu num só escrito semanal, como vimos procurando demonstrar.

Tanto na França quanto no Brasil, "a coincidência entre a esfera das pessoas ligadas às letras e aquela dos 'jornalistas' foi total” (Thérenty, 2007, p.13), ${ }^{14}$ mas, na França, a partir do anos 1850-1860, as "rubricas bem delimitadas (literatura, premier-Paris, crônica e crítica)" (ibidem, p.16) $)^{15}$ conheceram uma multiplicação considerável. Contemporâneos desses modelos de jornalismo, Machado de Assis e José de Alencar nos mostram que, no Brasil, ponto de vista e análise sobre a política e as variedades da semana, mais a preocupação com a

14 "la collusion entre la sphère des gens de lettres et celle des 'journalistes' est totale.» 15 "rubriques restreintes (littérature, premier-Paris, chronique et critique).» 
dimensão "entretenimento", compõem um texto em que aquilo que poderíamos denominar, de maneira geral, "estilo" conjuga invenção literária e jornalismo. Tudo isso foi organizado em um espaço que pertencia também ao romance-folhetim, que tinha ele próprio, como objetivo principal, a distração e o lazer. Dessa forma, fundindo-se todas essas tipologias textuais e seus objetivos no espaço do rodapé, a crônica que praticamos ainda hoje teria começado a se estruturar e, nas palavras de Antonio Candido (1993 p.23), "Até se poderia dizer que sob vários aspectos é um gênero brasileiro, pela naturalidade com que se aclimatou aqui e a originalidade com que aqui se desenvolveu". À definição do grande mestre, acrescentaríamos apenas o “jeitinho” brasileiro de conciliar o inimaginável.

\section{Referências bibliográficas}

ALENCAR, J. de. Como e porque sou romancista. Adaptação ortográfica de Carlos de Aquino Pereira. Campinas: Pontes, 1990.

Ao correr da pena. Edição preparada por João Roberto Faria. São Paulo: Martins Fontes, 2004. (Coleção Contistas e cronistas do Brasil). ASSIS, J. M. M. de. O Espelho. Organização, introdução e notas de João Roberto Faria. Campinas: Editora da Unicamp, 2009.

CANDIDO, A. A vida ao rés-do-chão. In: Recortes. São Paulo:

Companhia das Letras, 1993. p.23-9.

CANDIDO, A. et al. A crônica: o gênero, sua fixação e suas transformações no Brasil. Campinas: Editora da Unicamp; Rio de Janeiro: Fundação Casa de Rui Barbosa, 1992.

CHARTIER, R. (Dir.) Pratiques de la lecture. Marseille: Rivages, 1985.

Lectures et lecteurs dans la France de l'Ancien Régime. Paris: Éditions du Seuil, 1987.

ESPAGNE, M. Les transferts culturels franco-allemands. Paris, PUF, 1999.

GLEDSON, J. (Org.) Conversa de burros, banhos de mar e outras crónicas exemplares. Lisboa: Cotovia, 2006. v.14.

GRANJA, L. Antes do livro, o jornal: "Conto Alexandrino". Luso-Brazilian Review. v.46, p.106-14, 2009.

HABERMAS, J. L'espace public. Paris, Payot, 2008.

MARTINS, A. L.; LUCA, T. R. de. (Org.) História da imprensa no Brasil. São Paulo: Contexto, 2008. 
MEYER, M. Folhetim: uma história. São Paulo: Companhia das Letras, 1996.

MOREL, M. Os primeiros passos da palavra impressa. In: MARTINS, A. L.; LUCA, T. R. de. (Org.) História da imprensa no Brasil. São Paulo: Contexto, 2008. p.23-43.

O ESPELHO: Revista Semanal de Literatura, Modas, Indústria e Artes, edição fac-similar (1859-1860). Organização de Marco Lucchesi. Rio de Janeiro: Fundação Biblioteca Nacional, 2008

PINSON, G. Fiction du monde. De la presse mondaine à Marcel Proust. Montréal: Presses Universitáires de Montréal, 2009.

SODRÉ, N. W. História da imprensa no Brasil. São Paulo: Martins Fontes, 1967.

THÉRENTY, M.-E. La Littérature au quotidien. Poétiques journalistiques au XIXe siècle. Paris: Seuil, 2007.

THÉRENTY, M. E.; VAILLANT, A. (Dir.) 1836, L'an I de l'ère médiatique. Analyse littéraire et historique de La Presse de Girardin. Paris: Nouveau Monde, 2001.

Presse et Plumes. Journalisme et littérature au XIXe siècle. Paris: Nouveau Monde, 2004.

\section{Fontes primárias}

La Presse, Paris, julho de 1836; junho de 1838.

O Espelho, Rio de Janeiro, julho a dezembro de 1859.

Correio Mercantil, Rio de Janeiro, 1854.

Diário do Rio de Janeiro, Rio de Janeiro, 1864-1865. 


\author{
SOBRE O LIVRO \\ Formato: $14 \times 21 \mathrm{~cm}$ \\ Mancha: 23,7 x 42,5 paicas \\ Tipologia: Horley Old Style 10,5/14 \\ $1^{\text {a }}$ edição: 2010 \\ EQUIPE DE REALIZAÇÃO \\ Coordenação Geral \\ Marcos Keith Takahashi
}

